\author{
UNIVERSIDADE DE SÃO PAULO \\ MUSEU DE ARQUEOLOGIA E ETNOLOGIA \\ CURSO DE PÓS-GRADUAÇÃO EM ARQUEOLOGIA
}

\title{
A EXPLORAÇÃO DOS RECURSOS LITOLÓGICOS NA REGIÃo DA CIDADE DE PEDRA, RONDONÓPOLIS - MT
}

VALÉRIA CRISTINA FERREIRA E SILVA 


\title{
A EXPLORAÇÃO DOS RECURSOS LITOLÓGICOS NA REGIÃO DA CIDADE DE PEDRA, RONDONÓPOLIS - MT
}

\author{
Valéria Cristina Ferreira e Silva
}

Professor Orientador: Dr. Levy Figuti

Dissertação apresentada ao Programa de PósGraduação em Arqueologia do Museu de Arqueologia e Etnologia da Universidade de São Paulo para obtenção do título de Mestre.

São Paulo 


\section{BANCA EXAMINADORA}

MEMBROS TITULARES

Prof. Dr. Levy Figuti

Profa. Dra. Agueda Vilhena Vialou

Prof. Dr. Gilson Rodolfo Martins

MEMBROS SUPLENTES

Profa. Dra. Marisa Coutinho Afonso

Profa. Dra. Emilia Mariko Kashimoto 
"Nossa única certeza é a de que sempre seremos surpreendidos pelo inesperado."

Gunnar Myrdal

Dedicado à Selma Chiari (in memorian) $e$ Bernardo Silva Giacomel. 


\section{Agradecimentos}

Tanto a realização deste trabalho como a própria escolha profissional de tornarme arqueóloga não seriam possíveis sem o auxílio e companheirismo que recebi.

Um agradecimento inicial é dirigido ao meu orientador Levy Figuti e aos professores Agueda Vilhena Vialou e Denis Vialou, pela confiança, apoio e disposição em me aceitarem junto ao projeto Pré-História e Paleoambiente no Mato Grosso, do qual este trabalho é integrante.

Agradeço à FAPESP pelo financiamento dos dois anos em que desenvolvi esta pesquisa (Processo 02/11926-7).

À Deise, Vilmara e Veviane, toda minha gratidão pelo carinho, paciência, e confiança plena nos meus intuitos, mesmo quando eram totalmente abstratos.

À família Kesser Barcelos Dias (Carol, Camila, Eliana, José e Clarabóia), pela acolhida sempre amável e generosa.

À Selma Ires Chiari (in memorian), companheira de todos os momentos, agradeço por ter me ensinado o caminho das pedras.

À Rodrigo Meirelles, Patrícia Nalon, "Seu” Luiz e "Seu” Lázaro por terem me acompanhado nas longas caminhadas pela Cidade de Pedra e por toda as informações e troca de idéias.

À Gregório Ceccantini, por sempre me acolher em sua equipe quando era necessário, agradeço por ter me mostrado o que há além das rochas.

Um grande Obrigado a todos os funcionários da Fazenda Verde e toda a equipe de pesquisadores do projeto, em especial àqueles que estavam em campo no dia 13 de agosto de 2003, meus sinceros agradecimentos pela incessante busca.

Aos meus queridos amigos, Carol Kesser, Welitom Borges, Karin Shapazian, Maria Clara Migliacio, Emilio Camargo, Paula Nishida, Claúdia Plens, Camila Souza, André Penin, Camila Moraes, Luciane Monteiro, Flávio Calippo, Helena Lima, Vera Silva, Rodrigo Meirelles, agradeço pela participação, auxiliando nas mais diversas reflexões acerca de toda experiência vivida durante o período.

A todo os funcionários do Museu de Arqueologia e Etnologia da Universidade de São Paulo, agradeço o carinho e disposição em ajudar.

Ao Departamento de Recursos Minerais da Universidade Federal de Mato Grosso, agradeço pelo espaço cedido em seus laboratórios para análise do material. 
Aos professores, Dr. Francisco Pinho, Dr. Gerson Saes, Dr. Jayme Leite e Ms. Álvaro Quadros, agradeço pelo auxílio nas análises petrográficas e nas interpretações da geologia da região.

Aos professores Marisa Coutuinho Afonso e Paulo Antonio De Blasis, agradeço pelas valiosas sugestões sobre este trabalho.

A todos os membros da banca examinadora. 


\section{RESUMO}

O estudo da exploração das fontes de matérias-primas está vinculado a um entendimento do espaço em múltiplos aspectos, entre eles, o geográfico, o geológico, o biológico e, principalmente o cultural. Envolve a percepção dos recursos quanto à previsibilidade, distribuição, densidade, disponibilidade e diversidade em uma determinada área. A rocha, enquanto um desses recursos, é o objeto de estudo desse trabalho, que propõe promover uma discussão sobre as variações nas estratégias de captação e uso das matérias-primas líticas presentes na indústria de seis sítios arqueológicos inseridos na paisagem da região, hoje conhecida como Cidade de Pedra, localizada na Bacia do rio Vermelho em Rondonópolis, MT. Nessa perspectiva, foram utilizadas técnicas de mapeamento geológico e análise petrográfica a fim de localizar as possíveis fontes de captação de recursos litológicos e propiciar uma análise da potencialidade da matéria-prima lítica enquanto indicativo da dinâmica entre as atividades humanas e a paisagem. Dessa forma, foi possível verificar que a apropriação das matérias-primas varia entre os sítios arqueológicos, indicando a exploração de diferentes fontes de recursos petrográficos, sendo que a área abrangida para coleta de matérias-primas líticas pode atingir aproximadamente 20 quilômetros. 


\begin{abstract}
The research into the exploitation of raw material sources is linked to the understanding of space in multiple aspects such as geographical, geological, biological and most af all its cultural characteristics. It involves having insights into the predictability, distribution, density and diversity of resources within a specific area. Rocks, as one of these resources, are the study object of this project which aims at carrying out a discussion about the varying strategies for collecting and using lithological raw material found on the works of four archeological sites in the region nowadays known as Cidade de Pedra (Stone City), within the Vermelho river basin in Rondonópolis. Aiming at this, geological mapping and petrographical analysis techniques were used in order to locate potential collecting sources for lithological raw material. By doing so, visited areas could be determined to offer the possibility of analyzing the potentiality of the lithological material as an indicator of the dynamics between human activities and the landscape. It was then possible to confirm that appropriation of raw material fluctuates from one archeological site to another, indicating different methods of exploitation of petrographic resources, considering that the collection of lithological material covers an area of up to 20 kilometers.
\end{abstract}




\section{SUMÁRIO}

$\begin{array}{lll}\text { I) } & \text { Lista de Figuras } & \text { i } \\ \text { II) } & \text { Lista de Tabelas } & \text { ii } \\ \text { III) } & \text { Lista de Gráficos } & \text { iii }\end{array}$

1. Introdução. .1

\section{O Contexto da Ocupação Pré-Histórica na Região da Bacia do}

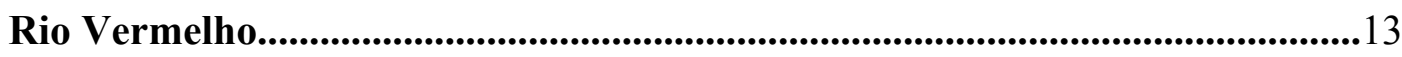

2.1. Características Ambientais da Bacia do rio Vermelho..........................13

2.2. Contexto Arqueológico da Bacia do rio Vermelho..............................15

2.3. A Área em Estudo: Características Gerais...........................................21

3. Caracterização Petrográfica da Matéria-Prima Lítica....................................22

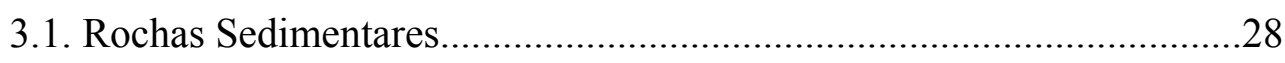

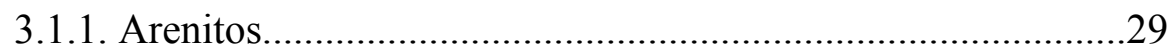

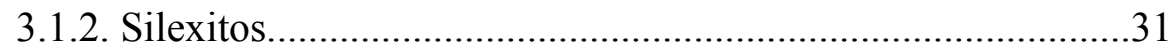

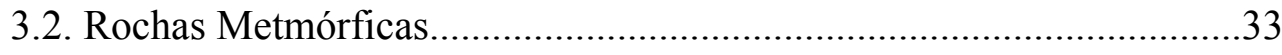

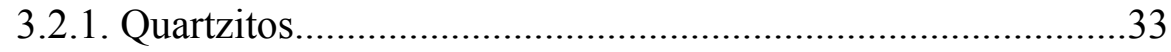

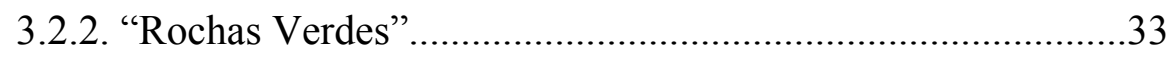

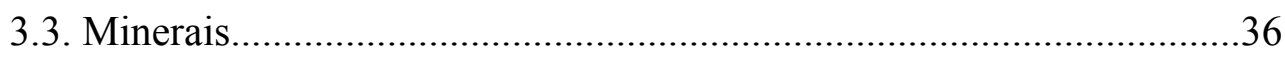

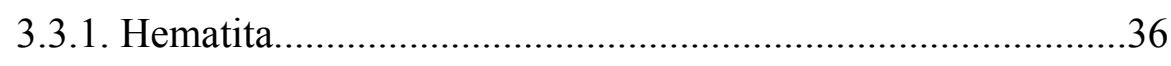

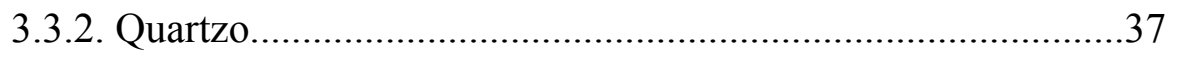

4. Caracterização Geológica: Proveniência do Material Lítico Arqueológico...38

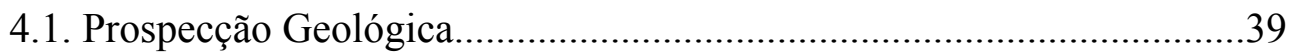

4.2. Caracterização geológica e proveniência dos arenitos e silexitos.........41

4.2.1. Os afloramentos de origem primária......................................43

4.2.2. Os afloramentos de origem secundária..................................45

4.3. Caracterização geológica e proveniência das rochas metamórficas.......46

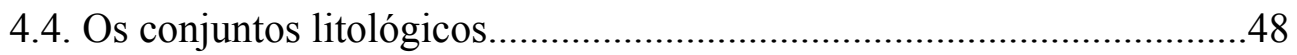


4.5. Os conjuntos litológicos e seus afloramentos .51

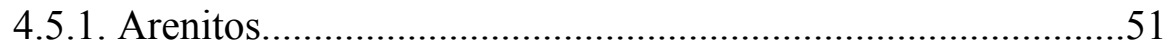

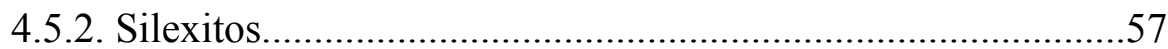

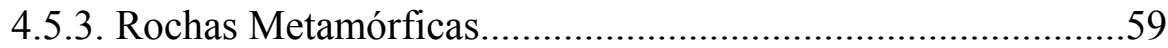

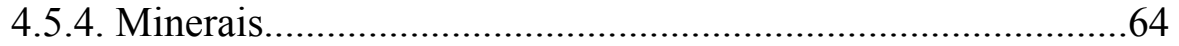

5. O Aproveitamento das Matérias-Primas Líticas na Cidade de Pedra..........67

5.1. Sítio Arqueológico Ferraz Egreja........................................................67

5.1.1. O Aproveitamento da Matéria-Prima Lítica...........................70

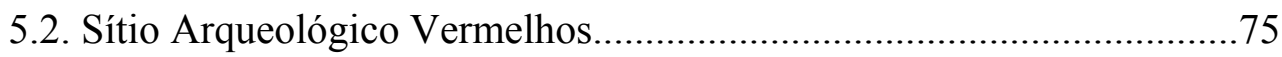

5.2.1. O Aproveitamento da Matéria-Prima Lítica...........................76

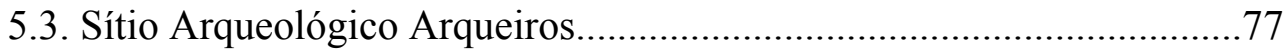

5.3.1. O Aproveitamento da Matéria-Prima Lítica...........................79

5.4. Sítio Arqueológico Caverna Antiqueira..............................................80

5.4.1. O Aproveitamento da Matéria-Prima Lítica..........................82

5.5. Sitio Arqueológico Caverna do Cipó...................................................82

5.5.1. O Aproveitamento da Matéria-Prima Lítica..........................84

5.6. Sítios Arqueológicos Fazendinha e Turbina.........................................85

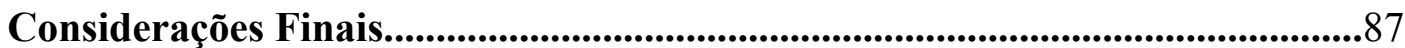

Referências Bibliográficas...................................................................................91 


\section{LISTA DE FIGURAS}

Figura 1. Localização do município de Rondonópolis, onde se realizam as pesquisas \# Página 23

Figura 2. Localização dos Sítios Arqueológicos na Cidade de Pedra (Concepção: $J-R$ Houller e T. Arnoux, 2002-2003) \# Página 24

Figura 3. Vista do sítio Ferraz Egreja (fotografia: K. Shapazian) \# Página 25

Figura 4. Detalhe do interior do abrigo do sítio Ferraz Egreja (fotografia: K. Shapazian) \# Págiana 25

Figura 5. Detalhe da escavação (fotografia: K. Shapazian) \# Página 25

Figura 6. Vista do sítio arqueológico Caverna do Cipó (fotografia:K. Shapazian) \# Página 25

Figura 7. Vista geral do sítio Cipó (fotografia:K. Shapazian) \# Página 25.

Figura 8. Subida até entrada da caverna do Cipó (fotografia:K. Shapazian) \# Página 25

Figura 9. Vista do morro onde se encontra a caverna Antiqueira (fotografia: $K$. Shapazian) \# Página 26

Figura 10. Sítio Antiqueira (fotografia:K. Shapazian) \# Página 26

Figura 11. Detalhe das escavações no sítio Antiqueira (fotografia:K. Shapazian) \# Página 26

Figura 12. Sítio Arqueiros (fotografia:K. Shapazian) \# Página 26

Figura 13. Detalhe da arte rupestre (fotografia:K. Shapazian) \# Página 26

Figura 14 - Trecho da trilha para o sítio Arqueiros (fotografia:K. Shapazian) \# Página 26

Figuras 15 e 16. Vista do sítio fazendinha sob dois ângulos (fotografia: Luciane. Monteiro)\# Página 27

Figura 17. Vista do sítio Turbina (fotografia: Luciane. Monteiro) \# Página 26

Figura 18. Mapa de Pontos (Concepção: Vilmara Silva) \# Página 40

Figura 19. Demonstração das formações geológicas que ocorrem nas áreas adjacentes à Cidade de Pedra (SEPLAN/MT, 1999) \# Página 42

Figura 20. Representação da foto aérea da área em estudo (Exército do Brasil) \# Página 44.

Figura 21. Vista da Cidade de pedra (fotografia: Denis Vialou) \# Página 44

Figura 22. Arenito do conjunto B \# Página 51 
Figura 23. Arenitos do conjunto A \# Página 51

Figura 24. Fotografia de lâmina petrográfica, objetiva 2,5 - Arenito do Conjunto A e B \# Página 52

Figura 25. Amostra do conjunto $\mathrm{C} / \mathrm{C} 2$ \# Página 52

Figura 26. Arenito do conjunto C \# Página 52

Figura 27. Arenito do conjunto C (Afl. 2) \# Página 52

Figura 28. Arenito do conjunto C (Afl. 2) \# Página 52

Figura 29. Amostra do conjunto $\mathrm{C} / \mathrm{C} 2$ localizados no afloramento 1 \# Página 53

Figura 30. Arenito "mosaico", Conjunto C/C2, afl. 1 \# Página 53

Figura 31. Arenitos/ quartzitos (conjuntos C/C2) - Afl. 6 \# Página 53

Figura 32. Material lascado associado ao Afl. 6 \# Página 52

Figura 33. Quartzito (Conjunto $\mathrm{C} / \mathrm{C} 2$ ): Fotografia de lâmina petrográfica, objetiva 2,5 \# Página 53

Figuras 34 e 35. Afloramento de arenito do Conjunto $\mathrm{C} / \mathrm{C} 2$ (fotografia: Rodrigo Meirelles) \# Página 54

Figura 36. Detalhe do afloramento do conjunto C/C2 (fotografia: Rodrigo Meirelles) \# Página 54

Figura 37. Exemplificação dos utensílios confeccionados em arenito com diferentes graus de silicificação (fotografia: Wagner Souza) \# Página 56

Figura 38. Ar-3 (Conjunto D) Fotografia de lâmina petrográfica, objetiva 2,5 \# Página 56

Figuras 39 e 40. Bloco de silexito nodular, localizado nos sedimentos transportados pelo rio Vermelho, a montante da Cidade de Pedra \# Página 57

Figura 41. Amostra de seixo de arenito friável com geodos de silexito coletado no rio Vermelho \# Página 57

Figura 42. Silexitos maciços, também provenientes do rio Vermelho \# Página 57

Figura 43. Conjunto de peças encontradas nos sítios Ferraz Egreja e Vermelhos (fotografia: Wagner Souza) \# Página 58

Figura 44 - Conjunto E: Fotografia de lâmina petrográfica de silexito maciço \# Página 58 
Figuras 45 e 46. Amostras do conjunto G1 (Afl. 3) (fotografia: Selma Chiari) \# Página 59

Figura 47. Conjunto G1: Fotografia de lâmina petrográfica, objetiva 2,5 \# Página 59

Figura 48. Vista da área de entorno, afloramento de quartzo-grauvaca (fotografia: Rodrigo Meirelles) \# Página 60

Figura 49. Afloramento de quartzo-grauvaca (fotografia: Rodrigo Meirelles) \# Página 60

Figura 50. Vista da área de entorno, feições geomorfológicas em arenito da Formação Furnas fotografia: Rodrigo Meirelles) \# Página 60

Figura 51. Vista da área de entorno, feições geomorfológicas em arenito da Formação Furnas fotografia: Rodrigo Meirelles) \# Página 60

Figura 52. Afloramento de quartzo-grauvaca (fotografia: Rodrigo Meirelles) \# Página 60

Figura 53. Afloramento de quartzo-grauvaca (fotografia: Rodrigo Meirelles) \# Página 60

Figuras 54 a 56. Amostras do conjunto G coletadas no afloramento 4 \# Página 61

Figura 57. Amostras de quartzo encontrados associados ao conjunto G \# Página 61

Figura 58. Conjunto G: Fotografia de lâmina petrográfica \# Página 62

Figura 59. Conjunto de "rochas verdes" (conjunto G) (fotografia: Wagner s. e Silva) \# Página 62

Figuras 60. Vista da Aldeia Bororo Piegaba (fotografia: Rodrigo Meirelles) \# Página 63

Figuras 61, 62 e 63. Afloramento visível devido à erosão provocada pela passagem do córrego Piegabre (fotografia: Rodrigo Meirelles) \# Página 63

Figura 64. Seixos/ plaquetas de hematitas, coletadas na drenagem (fotografia: Selma Chiari) \# Página 64

Figura 65. Ocorrência forma de carapaças ferruginosas na superfície do terreno (fotografia: Selma Chiari) \# Página 64

Figura 66. Sítios Arqueológicos em estudo e principais afloramentos de matéria-prima (EMBRAPA) \# Página 66

Figura 67. Representação da relação entre as possíveis fontes de matéria-prima e os sítios arqueológicos \# Página 67 


\section{LISTA DE TABELAS}

Tabela 1. Representação do esquema utilizado na formação dos conjuntos litológicos em laboratório \# Página 49

Tabela 2. Representação da formação dos conjuntos litológicos, com base nas fontes de matérias-primas \# Página 50

Tabela 3. Quadro cronológico dos sítios arqueológicos da Cidade de Pedra \# Página 69

Tabela 4. Distâncias aproximadas entre os conjuntos litológicos G e G1 em relação aos sítios arqueológicos \# Página 88

Tabela 5. Esquematização da relação entre os conjuntos de matéria-prima e os sítios arqueológicos \# Página 89

\section{LISTA DE GRÁFICOS}

Gráfico 1. Histograma representando a variação dos conjuntos litológicos entre as classes líticas do setor FEI do sítio Ferraz Egreja \# Página 72

Gráfico 2. Histograma representando a variação dos conjuntos litológicos entre as classes líticas do setor FEII do sítio Ferraz Egreja \# Página 73

Gráfico 3. Histograma representando a variação dos conjuntos litológicos entre as classes líticas do setor FEIII do sítio Ferraz Egreja \# Página 74

Gráfico 4.. Representação quantitativa dos vestígios arqueológicos do sítio Arqueiros \# Página 78

Gráfico 5. Representação quantitativa dos vestígios líticos do sítio Arqueiros \# Página 78

Gráfico 6. Histograma representando a relação entre os conjuntos litológicos e as classes líticas no sítio Arqueiros \# Página 79

Gráfico 7. Representação da relação quantitativa do material arqueológico no sítio Antiqueira \# Página 81

Gráfico 8. Variação quantitativa do material lítico do sítio Antiqueira \# Página 81 
Gráfico 9. Histograma representando a relação entre os conjuntos litológicos e as classes líticas no sítio Antiqueira \# Página 82

Gráfico 10. Variação quantitativa do material lítico do sítio Antiqueira \# Página 84

Gráfico 11. Histograma representando a relação entre os conjuntos litológicos e as classes líticas no sítio Caverna do Cipó \# Página 84 


\section{INTRODUÇÃO}

A arqueologia enquanto empreendimento científico é voltada, de maneira geral, para o entendimento da trajetória humana, seus métodos e materiais de estudo são intimamente ligados às Ciências da Terra, uma vez que as características do material estudado, bem como, o meio onde estão inseridos, são moldados por fatores cuja dinâmica é eminentemente natural (Araújo, 1999).

Essa relação entre arqueologia e ciências naturais, particularmente a geologia, se desenvolveu a partir da formulação de princípios geológicos que vieram a elucidar alguns problemas relacionados aos estudos sobre pré-história. Um destes princípios foi o da "superposição de camadas", enunciado por Nicolau Steno em 1669. Tal princípio dizia que, dada uma sucessão de camadas geológicas, aquela que está embaixo é sempre mais antiga que aquela que está em cima. Foi a partir deste princípio que Worsaae em 1843, através de uma mudança de escala, desenvolveu o "princípio de associação", no qual os artefatos encontrados em uma mesma camada teriam a mesma idade.

Outro princípio apresentado neste período foi o do "uniformitarismo", segundo o qual os processos existentes atualmente na terra seriam a chave para o entendimento do passado. Este princípio que para as ciências naturais apresenta uma série de ressalvas, vai servir de inspiração para alguns grupos de arqueólogos na década de 60 .

Sobre estas bases, no final do século XIX e início do século XX houve uma "revolução em termos de métodos", as escavações passaram a ser extremamente cuidadosas sem predileção por artefatos, onde, a estratigrafia e a proveniência individual dos artefatos eram dignos de registro. Entre os representantes desse período figuram, o General Pitt-Rivers, Flinders Petrie, Mortimer Wheeler e Alfred V. Kidder (Araújo, 1999).

$\mathrm{Na}$ década de 60 com o surgimento da "New Archaeology" houve uma preocupação em tornar a arqueologia mais científica e mais antropológica, nesse sentido, para testar suas hipóteses, os arqueólogos absorveram métodos analíticos da estatística para comparar a correlação da associação dos atributos dentro de uma classe de objetos ou para estudar a distribuição de artefatos nos sítios arqueológicos, sendo de grande importância os enfoques ambientais e ecológicos para explicar algumas mudanças no comportamento em função de mudanças ambientais (Gallay, 1986). 
Nesse contexto, algumas confusões acontecem ao se utilizar conceitos e paradigmas advindos da geologia e geografia, herdados do século XIX, sem haver uma adequação de escalas e objetivos. Também nesse período, tem início uma maior influência da geografia humana e da etnologia na pesquisa arqueológica (Daniel, 1975 apud Araújo, 1999) enquanto que nos Estados Unidos ocorre uma delimitação mais rígida das disciplinas Arqueologia e Antropologia versus Geologia. Segundo Araújo (1999), tais fatores teriam gerado um distanciamento entre geologia e arqueologia. Dessa forma, apesar da proveitosa colaboração entre arqueólogos, geólogos e geógrafos que já se fazia sentir desde o século XIX, a visão da necessidade de integração plena entre as geociências e a arqueologia demorava a acontecer, especialmente nos países sob maior influência da "New Archaeology". Em outros países, no entanto, como na França e outros vários países europeus, a Arqueologia está vinculada aos centros de Geologia do Quaternário havendo inclusive a utilização do termo correlato (Laboratoire de Geoarchèologie do Centre National de la Recherche Scientifique, Geoarchèologie como tema de pesquisa da Comission Suisse pour la Recherche sur le Quaternaire), sendo que nesse contexto, o termo está mais centrado na origem e constituição do quadro croestratigráfico e climático do Quaternário utilizando técnicas da geomorfologia (estudo da origem e das formas de paisagem), da sedimentologia (caracterização e gênese dos depósitos), da pedologia (estudo da formação dos solos), da estratigrafia (estudo das seqüências, da correlação dos sedimentos e dos paleosolos), da geocronologia (estudo do tempo dentro das seqüências estratigráficas) (Michel Guélat e Phillipe Rentzel, 2002-2005). No Brasil está situação não é definida e há núcleos de Arqueologia tanto em departamento de História como de Ciências Sociais.

Uma das primeiras tentativas de reaproximação entre as geociências e a arqueologia é de Karl Butzer, que na década de 70 introduziu o termo "GeoArqueologia" com uma conotação ecológica. A Geo-Arqueologia poderia contribuir com informações mais detalhadas sobre a estratigrafia e meio ambiente, podendo ainda, através de uma maior participação nas estratégias de escavação, resolver aspectos da interface da pesquisa relacionadas à preservação e demais fatores contextuais dos sítios. Segundo o autor, o geo-arqueólogo poderia ainda contribuir com significativas informações a respeito da disponibilidade e limitação dos recursos do ambiente e ajudar nas interpretações relacionadas à adaptação cultural dos grupos (Butzer, 1982). Butzer fez distinção entre o que seria uma Geologia realizada com viés ou aplicação 
arqueológica, chamada Geologia Arqueológica, de uma Arqueologia realizada com ajuda de métodos geológicos, então denominada Geo-Arqueologia. A dicotomia entre estes termos deveria estar relacionada ao objetivo da pesquisa.

Outro autor a trabalhar sobre o tema foi Collins Renfrew, ele considera a Geoarqueologia uma verdadeira ciência que emprega práticas das ciências geológicas no entendimento dos solos, sedimentos e formas de relevo em uma escala que permita a investigação das circunstâncias que governam a localização, a formação de depósitos e a preservação dos sítios arqueológicos.

Bruce Gladfelter (1977) por sua vez, acredita que Geoarqueologia diz respeito às contribuições das Ciências da Terra, particularmente, da Geomorfologia e da Petrologia Sedimentar, na interpretação e reconstrução do contexto arqueológico. $O$ autor considera que a adaptação humana no ambiente e a avaliação dos processos préhistóricos, incluem também uma reconstrução física dos arredores, sendo que para tanto há necessidade de contribuições das Ciências da Terra e outras disciplinas. Dessa maneira, esta designação por si própria implica na necessidade de integração de muitos dados, sendo o homem e a paisagem elementos cujas relações são importantes para um entendimento das atividades pré-históricas e suas associações.

Para Fekri Hassan (1979) o termo geoarqueologia é a contribuição das Ciências da Terra para a resolução de problemas geológicos relatados na Arqueologia. Hassan enfatiza ainda que a esfera de ação da Geoarqueologia é extensa e abrange, entre outros enfoques, o estudo tecnológico dos artefatos com o propósito de se determinar práticas de manufatura associados às fontes de matérias-primas, na busca de se proporcionar uma avaliação da dinâmica das relações entre as atividades humanas e a paisagem.

Todos os esforços realizados até então, no que se refere às diversas publicações sobre o tema, ainda não tinham surtido efeito no meio arqueológico, nesse sentido, Araújo (1999), considera que um dos maiores motores do desenvolvimento e aceitação da Geoarqueologia foi, na verdade, a abordagem reconstrucionista que em busca de uma compensação através de um corpo de conhecimentos que permitisse a tradução de "pedaços de pedra e ossos" em comportamento humano, detalhava cada vez mais os estudos nos sítios arqueológicos. Michael Shiffer teria canalizado esforços nessa perspectiva, fazendo a ligação entre ciências naturais e arqueologia em uma perspectiva e linguagem mais interessante aos arqueólogos. 
Shiffer produziu artigos enfatizando a necessidade de se entender as transformações por que passava o registro arqueológico, antes de se reconstruir o comportamento humano sendo o registro arqueológico o objeto de estudo a partir do qual inferências comportamentais poderiam, talvez, ser realizadas.

Schiffer (1972) elaborou o modelo de fluxo, onde estão representadas, dentre as atividades desenvolvidas pelo grupo, aquelas que podem gerar cultura material. Essas atividades correspondem à procura, manufatura, utilização, reutilização e descarte da cultura material que resultará numa determinada configuração do registro, sendo essa configuração o resultado de processos naturais e culturais. Dessa forma, os processos naturais de formação do registro arqueológico, são aqueles sujeitos a todos os acontecimentos e processos pós-deposicionais provenientes do ambiente natural que atuam sobre os depósitos arqueológicos, podendo contribuir tanto para sua destruição, quanto para sua preservação, alguns exemplos desses processos são: intempirismo, erosão, sedimentação e ação dos agentes biológicos. Já os processos culturais, encontram-se vinculados ao comportamento humano presente nas atividades de produção, uso e descarte dos itens materiais representados no registro arqueológico. Referem-se também a todas as intervenções culturais posteriores, como processos de reocupação dos contextos arqueológicos por distintas populações, o reuso dos materiais arqueológicos e mesmo as atividades dos arqueólogos durante a descoberta e análise dos vestígios materiais (Schiffer, 1987).

Desde então, as abordagens relacionadas a Geoarqueologia cresceram, ao mesmo tempo em que as expectativas reconstrucionistas eram frustradas, pois nada parecia ser bem o que se pensava, o registro arqueológico é uma entidade física com características próprias, e por isso algumas abordagens são mais bem sucedidas que outras (Araújo, 1999).

No Brasil, trabalhos voltados a geoarqueologia têm sido desenvolvidos principalmente no âmbito acadêmico, tais como Afonso, 1988, 1995; Araújo, 1994; Kashinomoto, 1992, 1997; Faccio 1992,1998; Martins, 1999; Morais, 1983, 1998.

A proposta desta dissertação é apresentar uma análise sobre um dos temas abordados pela geoarqueologia, que é a relação entre a captação de recursos petrográficos e os utensílios líticos, através da identificação e localização das áreas fontes de matérias-primas utilizadas pelos grupos que habitaram a região, hoje conhecida como "Cidade de Pedra", situada numa porção da bacia do rio Vermelho a 
sudeste do Estado do Mato Grosso em Rondonópolis. Dessa forma, analisar a potencialidade da matéria-prima lítica, enquanto indicativo da dinâmica das relações entre uma das atividades humanas e a paisagem.

Esse trabalho vem incorporar uma série de estudos realizados no âmbito do programa de pesquisas Pré-História e Paleoambiente no Mato Grosso, que desenvolve pesquisas na área desde 1984. A longo desse período cerca de sessenta sítios arqueológicos foram descobertos, dentre os quais alguns apresentaram condições que permitiram escavações, que de acordo com a metodologia aplicada, foram escavados em superfícies amplas. O material lítico proveniente destas escavações é o objeto de estudo desse trabalho. Trata-se de um material cuja proveniência era desconhecida em detalhes, impossibilitando uma análise mais completa da cadeia de operações realizada na indústria lítica.

Para tanto, esse trabalho apresenta em um primeiro momento algumas considerações sobre os estudos relacionados à matéria-prima lítica e alguns conceitos abrangidos pelo tema: paisagem, espaço, território. Em seguida uma apresentação das pesquisas arqueológicas desenvolvidas na região da bacia do rio Vermelho, principalmente aquelas desenvolvidas em âmbito acadêmico. Foram feitas também algumas considerações sobre a relação entre os dois domínios ambientais existentes na área em estudo, cerrado e pantanal.

Detalhando os estudos, é então apresentado os principais aspectos dos sítios arqueológicos dos quais a matéria-prima lítica foi estudada. Posteriormente foi feita uma caracterização petrográfica e geológica a fim de demonstrar a relação entre a matéria-prima encontrada no sítio e aquela que está disponível nos afloramentos rochosos da região.

A partir daí buscou-se fazer uma análise da utilização das diferentes categorias de matéria-prima e classes líticas de cada sítio. Com o desenvolvimento destes temas, se pretendeu um entendimento das estratégias adotadas na obtenção da matéria-prima lítica pelos grupos pré-históricos dos quais foram detectados vestígios nessa porção da Bacia do rio Vermelho, uma vez considerado que as estratégias de obtenção de matéria-prima entre os grupos pré-históricos pode variar em consequiência da configuração geológica do espaço explorado. 


\section{Capítulo 1}

\section{Áreas Fontes de Matéria Prima-Lítica e sua Inserção na Paisagem: Algumas Considerações}

\subsection{Matéria-prima lítica: potencialidades de análise}

A obtenção das matérias-primas líticas enquanto enfoque geoarqueológico tem sido explorado em livros sobre Geoarqueologia como dos autores Rapp e Hill (1998) que dedicam um capítulo ao tema. Para os autores a determinação da proveniência tem três componentes maiores que envolvem: 1) a localização e amostragem para analise do potencial da fonte do depósito geológico do material em questão; 2) a escolha de um método analítico que tenha suscetibilidade e alcance para proporcionar a identificação das características diagnósticas de cada depósito geológico respectivo aos artefatos; 3 ) a escolha estatística de técnicas de análise que possam avaliar o dado e que designem os artefatos de acordo com os seus depósitos de origem.

Segundo os autores, os estudos de proveniência baseiam-se no fato de que há características físicas, químicas ou minerais das fontes de matéria-prima que permanecem no artefato final. Para detectá-las, a Geoarqueologia pode utilizar parâmetros químicos, físicos e biológicos, a fim de encontrar itens distintivos entre as jazidas. O significado arqueológico que essas informações podem dar concerne ao fato de que eles podem servir de evidência para a construção de modelos de sistemas de troca e rotas de comércio, oferecendo também a dimensão do território e localização dos recursos que podem estar relacionados à estratificação social e organização do trabalho.

Por outro lado, Renfrew et al. (1991, apud 1993) comenta que de um modo geral, a etnografia e o sentido comum fazem pensar que o homem tenderia a utilizar qualquer material de que dispusesse facilmente e em abundância para as tarefas mais cotidianas, e que investiria tempo e esforços na fabricação das ferramentas que utilizaria repetidamente e que levaria consigo. Por tanto, a abundância de um tipo de utensílio no registro arqueológico não necessariamente é um sinal de sua importância na cultura, pois o utensílio encontrado com maior frequiência pode ter sido aquele elaborado com rapidez e deixado imediatamente após sua utilização, no entanto o utensílio mais raro 
seria guardado e reutilizado em várias ocasiões antes que fosse abandonado em um dado momento.

Renfrew et al. comenta ainda sobre a importância da caracterização petrográfica do material lítico através de métodos analíticos, tais como a análise microscópica em lâmina delgada como forma de determinar seu lugar de origem, porém a localização da origem desses materiais vai depender do conhecimento que se tem sobre a distribuição das matérias-primas na natureza, desse modo um mapa geológico é uma base necessária para um estudo sólido do lugar de procedência.

Alguns estudos de caso referentes às matérias-primas líticas podem ser aqui apresentados, tal como o trabalho realizado por William Andrefsky (1994), que propõe a partir de exemplos etnográficos dos produtores de artefatos em rocha na Austrália e exemplos arqueológicos de diferentes áreas no oeste do Estados Unidos que a disponibilidade de matéria-prima lítica é um dos condicionantes mais importantes na tecnologia de produção de artefatos em rocha. Percebeu-se que certas características, como a abundância e a qualidade da matéria-prima lítica são fatores importantes na produção de artefatos formais versus artefatos informais. Matérias-primas de baixa qualidade tenderiam a ser utilizadas nos artefatos informais, enquanto que, matériasprimas de alta qualidade tenderiam ser utilizadas nos artefatos formais quando estas são abundantes. Quando materiais de alta qualidade são muito abundantes, os artefatos formais e informais tendem a ser produzidos. Outros fatores, como mobilidade residencial e sedentarismo seriam então características menos importantes na tecnologia de produção lítica.

Ampliando o leque de discussões, Ricklis e Cox (1993) ao estudarem a fase tardia pré-histórica da costa central do Texas, sugerem que a organização tecnológica lítica parece ter se ajustado às necessidades mais fundamentais de se obter recursos bióticos. Como resultado, a eficiência lítica não era constante e flutuou dentro de um subsistema cultural dinâmico que se articulou com as demandas de operações adaptativas gerais.

De um modo geral, as pesquisas sobre matéria-prima estão vinculadas aos estudos sobre tecnologia lítica realizados no âmbito do que Leroi-Gourhan chamou de "châine opératoire", a partir da qual se da o processamento dos implementos líticos e cerâmicos pelas comunidades pretéritas. Esta cadeia, em síntese, envolve a busca pela matéria-prima, as técnicas de processamento, o uso do instrumental e o seu descarte, 
sendo que, tanto na análise do material lítico como cerâmico, é considerado o aporte das geociências. Essa descrição, porém, não é um fim em si mesma, mas deve ser feita com o intuito de se compreender por que cadeias operatórias se apresentam de uma determinada maneira e não de outra e, ao mesmo tempo, porque determinadas escolhas tecnológicas foram feitas e como elas estão relacionadas aos demais aspectos do sistema cultural (Silva, 2000), esta sequiência de operações é também de certa forma representada no modelo de fluxo proposto por Shiffer (1972).

Nessa perspectiva, vários estudos foram desenvolvidos com ênfase na matériaprima lítica. Para Tixier et al (1980), a obtenção de matérias-primas líticas apesar de parecer um problema simples acarreta múltiplas respostas com numerosas combinações e um amplo leque de hipóteses sendo que a presença ou ausência de rochas aptas ao lascamento nas proximidades dos sítios já representa um dado complexo. O autor comenta ainda, que a ausência total de rochas aptas ao lascamento é raro, mas que sua presença e acessibilidade aos grupos pré-históricos oferecem numerosas interpretações que comprometem obrigatoriamente as dimensões, e algumas vezes, a morfologia dos utensílios. Além do território de aprovisionamento lítico, deve-se considerar que cada grupo pré-histórico vai ter um comportamento próprio diante dos mesmos recursos de matéria-prima.

Sellet (1993) por sua vez, acredita que uma análise sobre obtenção de recursos minerais deveria servir para determinar os tipos de matérias-primas trazidas e usadas no sítio, sua respectiva importância quantitativa e qualitativa no sistema, além da sua morfologia primária e o processo de transporte (obtenção direta ou indireta). Para o autor, à distância dos recursos tem sido prevalecente nos estudos de obtenção de matéria-prima lítica, sendo as distâncias lineares tradicionalmente utilizadas para inferir o tipo de obtenção, se comércio ou obtenção direta. Cada medida, no entanto, comprova sempre que o afloramento foi visitado e não expressa a extensão do território que foi explorado, além disso, diferentes proporções de matéria-prima são uma consequiência direta do modelo organizacional do grupo, portanto, definindo as funções de diferentes matérias-primas no sistema lítico, pode-se ter um entendimento completo das estratégias de produção, uso e descarte.

Aubry (1991) desenvolveu uma série de pesquisas relacionadas à exploração de recursos líticos na bacia do Creuse, na França e também na região do Vale do Côa em Portugal (Aubry et al, 2000, 2002), no Brasil pesquisas forma feitas em Rondonópolis, 
na região da Cidade de Pedra e em Jangada no sítio arqueológico Santa Elina (1999, 2005). Aubry aplica em seus trabalhos um extenso levantamento geológico da área, associado a uma identificação das matérias-primas presentes nos sítios que por sua vez, são agrupadas em conjuntos sendo estes conjuntos relacionados a uma determinada área fonte de matéria-prima lítica. Nos sítios europeus estudados (Aubry et al 2000, 2002) podem ocorrer grandes distâncias entre as fontes de matéria-prima lítica e seu local de origem, isso gera um determinado números de hipóteses que levam em consideração, estratégias de difusão ao se considerar as grandes distâncias entre o material e sua fonte, que podem ir de 30 a 150 quilômetros. Essa diferença nas distâncias entre sítio e área fonte tende a gerar modelos de difusão distintos no que tange aos deslocamentos que um grupo pode fazer em um dado território durante um ciclo anual.

Nos estudos realizados com o material lítico do sítio Santa Elina, Aubry (2005) demonstrou boa parte do material lítico encontrado no abrigo estava disponível a menos de 5 quilômetros do sítio indicando um bom conhecimento dos recursos líticos de afloramentos localizados nas imediações do abrigo, sendo uma parte do material com má aptidão ao lascamento.

Vilhena Vialou (2005), considera que o homem confecciona utensílios de acordo com as rochas de que dispõe, sendo este um dos elementos que permitem distinguir sítios arqueológicos em função de suas fontes de matéria-prima. Dentre as possibilidades de matéria-prima em uma região haverá uma escolha dentre a diversidade de que dispõe para confecção de certos instrumentos, existindo aí uma real adequação entre rocha e tipo de utensílio (Vilhena Vialou, 2005; Leroi-Gourhan, 1984).

Segundo Vilhena Vialou (2005) os fatores determinantes na escolha das matérias-primas estão fundamentalmente ligados à sua localização em relação ao habitat, sendo assim, três grandes tipos podem ser distinguidos: rocha local, rocha das proximidades e rocha importada (alóctone). Afora a possibilidade de troca e intercâmbio, os grupos, moradores de uma dada região, não tendem a fazer seus instrumentos habituais de trabalho com materiais de local distante (mais de $50 \mathrm{~km}$ de distância). De modo geral, o ser humano adapta-se à geologia da região onde habita, ocasionalmente podem vir de longe alguns materiais diferentes por serem especiais e significativos para o grupo. 


\subsection{A escolha da matéria-prima lítica enquanto exploração do espaço/paisagem}

O espaço tem sido uma preocupação da arqueologia há muito tempo, tendo se intensificado durante a "Nova Arqueologia", na década de 60, dando ênfase à arqueologia espacial e aos estudos sobre assentamento, com uma forte influência da "Nova Geografia". Ao se analisar a paisagem como o espaço socialmente construído, observa-se que ela se altera ao longo do tempo e que o olhar dos grupos humanos também se modifica (Afonso, 2000).

A partir daí começa a se desenvolver a Arqueologia da Paisagem (Landscape Archaeology) que envolve a discussão do conceito de sítio arqueológico e faz uso de geotecnologias para identificar, registrar e gerenciar informações (Afonso, 2000). Nesse sentido, Roberts (1987 apud Afonso, 2000) considera que as paisagens podem ser definidas como conjuntos de feições do mundo real - natural, semi-natural ou totalmente artificial - que dão características e diversidade à superfície da Terra e formam o arcabouço físico no qual as sociedades humanas existem.

O estudo da exploração das fontes de matéria-prima, por sua vez, está relacionado ao entendimento do espaço em múltiplos aspectos, entre eles, o geográfico, o geológico, o biológico e, principalmente, o cultural. Envolve a percepção dos recursos quanto a sua previsibilidade, distribuição, densidade, disponibilidade e diversidade em uma determinada área, considerando também que a variação desses fatores podem ser examinadas quanto a sua disponibilidade e seleção ao longo de uma dimensão espaçotemporal (Ambrose, 1990).

Uma discussão sobre variações na captação e uso da matéria-prima utilizada em uma indústria lítica deve estar vinculada aos fatores relacionados à escolha, que por sua vez pode se ater a diversos parâmetros.

Para Lemonier (1993), os processos de seleção dos procedimentos técnicos a serem adotados na transformação e ação sobre o mundo material, resultam de um aprendizado, no interior de cada sociedade, de como as coisas devem ser feitas e usadas. Determinada escolha pode estar vinculada a uma imposição ecológica, mas pode também estar relacionada a fatores sociais e simbólicos, considerando que os objetos apresentam um conteúdo simbólico, histórico e funcional, e que todos eles devem ser relevantes no estudo da cultura material (Ribeiro, 1985). 
A procura, seleção e utilização dessas matérias-primas podem ser estudadas enquanto uma interpenetração de diferentes significados contextuais que poderão ser entendidas a partir da noção de sistema tecnológico (Leroi-Gourhan, 1984). Todavia, entende-se o estudo da captação e seleção de matérias-primas enquanto parte integrante da tecnologia lítica, não podendo ser encarado unicamente, como um índice de adaptabilidade, mas sim como uma opção que se relaciona com a construção social, e é motivada não somente por razões práticas. Isso não exclui, no entanto, a importância dos dados fornecidos pelo estudo da relação dos grupos pré-históricos com o meio habitado, pois o estabelecimento dessas relações é fundamental em uma pesquisa sobre territorialidade ao se considerar que o controle e uso do espaço, e dos recursos nele distribuído, são uma forma de conduta territorial (Dyson-Hudson et al, 1978). Nesse sentido Higgs e Vita-Finzi (1970) desenvolveram pesquisas quanto às áreas de captação de recursos dos sítios (site catchment analysis) explorando a relação entre recursos ambientais disponíveis na vizinhança de um assentamento e seus possíveis padrões de exploração sazonal. Assim sendo, a importância do espaço enquanto recurso é sempre relevante, pois as populações humanas não podem ser estudadas isoladamente, uma vez que os sistemas adaptativos estão interligados (Clark, 1977).

As rochas utilizadas para a confecção dos utensílios líticos são apenas um desses recursos que dependendo do contexto arqueológico e geológico da área, pode ser um recurso viável para indicação do espaço freqüentado.

A questão do espaço freqüentado para a coleta da matéria-prima lítica, está ligada aos estudos sobre adaptabilidade dos grupos ao meio, e este por sua vez, vinculase a mobilidade, subsistência e sistema de assentamento. Sobre esses temas, Binford gerou modelos utilizando a relação existente entre o Homem e o meio, considerando que o universo simbólico tem um papel funcional e que todo simbolismo encontra-se vinculado à sobrevivência. Em 1980, este autor introduziu o termo "forrageiro-coletor" para explorar os sistemas de mobilidade e a organização dos caçadores-coletores. Esse modelo pode ser empregado em diferentes níveis, de maneira que incorpore tanto as manifestações arqueológicas dos sistemas de assentamento como as particularidades do mesmo. Binford ressalta ainda que os grupos forrageiros e coletores não são dois tipos de sistemas de assentamento e subsistência opostos e que ambos podem estar presentes na organização de uma sociedade. Entende-se assim, que não há um nomadismo, mas um território de domínio que acompanha uma sazonalidade. 
Outros modelos definidos por Binford são as tecnologias de curadoria e expediente. A tecnologia de curadoria se faz a partir da resposta antecipada a uma necessidade humana, a matéria-prima é coletada com um objetivo premeditado. Há uma maximização da obtenção da matéria-prima devido a uma antecipação do uso, podendo ocorrer, às vezes, a armazenagem. A tecnologia de expediente vem como resposta imediata a uma necessidade humana, onde o artefato é feito para resolver um problema momentâneo e que vai em seguida, ser descartado. Não há necessariamente uma padronização.

Assim, estudos têm sido desenvolvidos com o objetivo de identificar os diferentes processos culturais que resultam na variabilidade das escolhas tecnológicas, principalmente, quanto as suas possíveis causas. 


\section{Capítulo 2}

\section{O Contexto da Ocupação Pré-Histórica na Região da Bacia do Rio Vermelho}

\subsection{Características Ambientais da Bacia do rio Vermelho}

Numa área de transição entre o planalto e a planície do Pantanal Matogrossense, no contexto do rio Vermelho, afluente dos rios São Lourenço e Cuiabá, insere-se uma paisagem ruiniforme de morros-testemunhos areníticos, que se estendem por vários quilômetros, numa área conhecida localmente como "Cidade de Pedra", que abriga entre seu acidentado relevo um conjunto de sítios arqueológicos. Tal denominação é recorrente em todo o país, e relaciona-se as curiosas formas geradas pela ação da erosão sobre as formações sedimentares areníticas.

A região do planalto é tomada pelo domínio dos cerrados (Ab'Saber, 1977), que ocupa, predominantemente, os maciços planaltos de estrutura complexa, dotados de superfícies aplainadas de cimeira, abrangendo também um conjunto significativo de planaltos sedimentares compartimentados, situados a níveis de altitude que podem variar de 300 a 1700 metros, no caso da área de estudo estas altitudes chegam a 600 metros. As formas de terreno são, em sua maioria, similares tanto nas áreas de solos cristalinos aplainados como nas áreas sedimentares mais elevadas, transformadas em planaltos típicos, como é o caso da porção de Bacia do Paraná onde se encontra a área em estudo. Nessas áreas é comum ocorrer bancadas de laterita, na cimeira dos platôs, onde aparecem os mais degradados fácies naturais de cerrados: campos pontilhados de arboretas anãs (Ab'Saber, 2003).

$\mathrm{Na}$ paisagem observada pelo homem, no domínio dos cerrados e cerradões, predominam interflúvios e vertentes suaves dos diferentes tipos de planaltos regionais. As verdadeiras florestas de galeria, algumas vezes, ocupam apenas os diques marginais do centro das planícies de inundação, em forma de corredor contínuo de matas; outras vezes, quando o fundo aluvial é mais homogêneo e alongado, ocupam toda uma calha, sob a forma de serpenteantes corredores florestais (Ab'Saber, 2003).

Freqüentemente, em algumas áreas, as florestas de galeria estendem-se continuamente pelo setor aluvial central das planícies, deixando espaço para corredores 
herbáceos nos seus dois bordos, arranjo fitogeográfico reconhecido pelo nome popular de veredas, que podem formar grandes caminhos naturais para a circulação animal (Ab'Saber, 2003).

Durante o período seco, que ocorre no meio do ano, alguns cursos d'água principais e secundários emagrecem ou desaparecem. O ritmo marcante do tropicalismo regional, com estações muito chuvosas alternadas com estações secas implica uma preservação intensiva dos padrões de perenidade os cursos d'água regionais. Ainda assim permanecem os canais de escoamento laterais dos chapadões que formam uma linha úmida d'água quase superficial, que atravessa toda a estação seca no meio do ano (Ab'Saber, 2003).

$\mathrm{Na}$ transição para as terras baixas a vegetação savânica ainda se mantém representada por fisionomias como Savana Arborizada (Cerrado típico), Savana Florestada (Cerradão), Savana Parque (Campo de Murundus). Esse mosaico de feições de cerrado oferece um conjunto significativo de espécies vegetais de possível aproveitamento para uma economia de subsistência, a exemplo do jatobá (Hymenaea stigonocarpa), Embaúba (Caryocar brasiliense), tucum (Bactris glaucescens), entre outras.

A cobertura pedológica na área é bastante diversificada em função de processos genéticos, comportamento hídrico e morfologia das vertentes. No nível do Planalto, onde se desenvolvem amplos interflúvios, os topos são constituídos por Latossolos Vermelho Escuros, relacionados aos sedimentos neogênicos detrito-lateríticos, e Areias Quartzosas, concentradas em pequenas áreas, formando também grandes extensões de solos litólicos na área (Vasconcelos et al., 1999).

Ao longo das vertentes, estes solos passam de maneira gradativa para Latossolos Vermelho Escuros e Latossolos Vermelho Amarelos de textura argilosa a média nos setores intermediários, até Areias Quartzosas Hidromórficas e Gleis Pouco Húmicos, nas posições de baixa vertente e fundo de vale. Os solos hidromórficos são basicamente Plintossolos, Gleis e, ocasionalmente, Areia Quartzosa Hidromórfica, passando às vezes, em áreas deprimidas, recobertas por vegetação florestal, para Solos Orgânicos.

$\mathrm{Na}$ transição Planalto/Depressão, verifica-se a ocorrência de Plintossolos concrecionários, associados a Latossolos Vermelho Amarelos Plínticos, de textura média sobre os afloramentos rochosos. 
O tipo climático regional é dominantemente o Aw de KOPPEN (Tropical Chuvoso), caracterizado por ser um clima quente e úmido, com duas estações definidas: uma chuvosa, e outra seca coincidente com o inverno, variando de três a cinco meses e ocorrendo geralmente de maio a setembro. A precipitação média anual está me torno de $1.750 \mathrm{~mm}$, e temperatura média de $25,5^{\circ} \mathrm{C}$ (Amaral et al., 1982 apud Vasconcelos et al, 1999).

A fauna, por sua vez, encontra-se associada a esses remanescentes de vegetação natural, principalmente nas formações savânicas, sendo estas reconhecidas pela população como sendo compostas, sumariamente, por Tamanduás (Myrmecophaga tridactyla e tetractyla); Tatus (Priodontes maximus, Dasypus nocintus, Tolypeutes tricinctus); Lobos Guará (Chrysocyon brachyurus); Lobinhos (Cerdocyon thous); Antas (Tapirus terrestris); Veados (Ozotocerus bezoarticus, Mouzama gouazoubira e americana); Preás (Cavia sp.); Pacas (Agouti paca); Cutias (Dasyprocta azarae); Garças (Bubulcus íbis); Lagartos (Aneiva aneiva, Tupinambis teguixim, Tropidurus spinulosus); Cobras (Bothrops moojeni, Crotalus durissus).

\subsection{Contexto Arqueológico da Bacia do rio Vermelho}

A bacia hidrográfica do rio Vermelho, localizada no sudeste do Mato Grosso, é uma das regiões arqueologicamente mais estudadas do Estado.

As pesquisas realizadas no âmbito de dois projetos, especialmente, produziram estudos sobre a arqueologia da região que evidenciaram uma seqüência de ocupações pré-coloniais que vão desde o início do Holoceno, há cerca de 11 a 12 mil anos, até o século XVII, quando grupos Bororo entraram em contato com frentes da ocupação européia. São eles:

a) O programa de pesquisa Pré-História e Paleoambiente no Mato Grosso, do qual está pesquisa faz parte, que é desenvolvido em cooperação entre o Muséum National d'Histoire Naturelle e Museu de Arqueologia e Etnologia da Universidade de São Paulo, sob a coordenação atual dos arqueólogos Denis Vialou, Águeda Vilhena Vialou e Levy Figuti, que possibilitou a publicação de vários trabalhos acadêmicos e artigos. 
b) O Projeto Etno-arqueológico e Arqueológico da Bacia do Rio São Lourenço, MT, coordenado pela arqueóloga Irmhild Wüst, e que possibilitou a elaboração de sua tese de Doutorado, concluída em 1990 na Universidade de São Paulo, além de vários artigos, publicados em revistas especializadas.

A ocupação mais antiga na área da bacia do rio Vermelho, até o momento, foi registrada por Wüst (1990), e data de 10.080 + ou - 80 anos BP. Refere-se à ocupação da área por grupos caçadores-coletores que produziram uma indústria lítica que a autora considera filiada à tradição Itaparica, esta definida a partir de uma indústria lítica datada do período de transição pleistoceno/holoceno, em Pernambuco (Schmitz, 1987; Prous, 1992; Fogaça, 1995; Schmitz et al., 2004). Indústrias semelhantes são registradas numa ampla região, que vai do nordeste brasileiro ao Brasil Central.

A indústria lítica Itaparica é descrita como uma indústria de lascas caracterizada pela predominância de instrumentos unifaciais produzidos por percussão dura, com trabalho secundário de percussão ao longo de todos os bordos somente em alguns de seus raspadores alongados e plano-convexos com e sem aresta dorsal (Schmitz, 1987 apud Wüst, 1990). Seu "traço-diagnóstico" tem sido a presença de "lesmas", algumas apresentando marcas de encabamento (Schmitz et al., 2004). A matéria-prima predominante é o arenito silicificado, seguido por alguma "calcedônia" e algumas outras rochas que aparecem em pouquíssima quantidade.

Esta ocupação estaria associada a uma economia de caça e coleta generalizada, e ocuparia ambientes de vegetação aberta, como a caatinga, o cerrado e o campo limpo. Os restos alimentares registrados em um abrigo em Goiás (GO-JA-01) e que correspondem a esta ocupação, compõem-se de animais de grande e médio porte: cervídeos, carnívoros roedores, tatus e répteis (Jacobus, 1983 apud Wüst 1990:58).

Os vestígios desses grupos caçadores-coletores aparecem tanto em abrigos sobrocha, quanto a céu aberto, embora este último caso seja considerado bastante raro, faltando ainda o seu estudo (Prous, 1992).

Para Bacia do rio Vermelho Wust propõe duas classes de assentamentos: sítioshabitação e acampamentos temporários, sendo que nos rios das Garças e Vermelho, a indústria lítica mais antiga se assemelha à do período tardio da tradição Itaparica.

Para o período subseqüente, no optimum climaticum, de 5.000 aC até a era Cristã, Wüst (1999) indica abrigos no sudeste de Mato Grosso, com indústrias líticas 
consideradas "locais", que seriam ainda pouco definidas, devido ao material coletado ser apenas de curadoria de instrumentos.

Segundo Schmitz (2000), nesse período (6500 a.C. até a chegada dos horticultores), deve ter havido um clima com temperatura e umidade ascendentes e na vegetação um adensamento significativo em relação ao período anterior. Segundo o autor, inicialmente, os mesmos abrigos continuaram a ser ocupados, sem continuidade estratigráfica, mas no clímax de temperatura e umidade, por volta de 4 mil a 2 mil anos a.C., esta ocupação se reduz porque o espaço se tornou menos adequado e a população passou a se estabelecer mais intensamente em lugares a céu aberto. Na indústria lítica que aparece nesse período, identificada em Serranópolis, no sudeste da Bahia e em Caiapônia, desaparecem as peças bem trabalhadas, sendo estas substituídas por lascas com pequenos bordos denticulados, bicos, pontas-entre-entalhes, ou simplesmente com bordos regularizados. Como desaparece o fino acabamento dos raspadores, desaparecem também as características lascas de redução secundária, os artefatos continuaram unifaciais, mas muito menos trabalhados. Schmitz comenta ainda sobre a matéria-prima dos artefatos lascados, que antes era predominantemente quartzito em grandes blocos, agora aparece também a "calcedônia", presente em blocos muito menores, no entanto, é mais difícil separar as ocupações a céu aberto daquelas do período anterior porque os artefatos encontrados são pouco definidos e semelhantes a alguns que já vinham aparecendo.

Na área da bacia do Vermelho - São Lourenço, de acordo com Wüst (1999, 1990), por volta de 800 a.C., teriam ocorrido mudanças no padrão de assentamento, registrando-se então sítios a céu aberto em áreas de transição entre áreas de mata e de cerrado. Nesta época teriam se desenvolvido as primeiras práticas agrícolas, ainda em contexto pré-cerâmico. A indústria lítica Tombador, associada a esta ocupação, seria caracterizada por grandes lascas de quartzo, obtidas por percussão dura e ocasionalmente técnica bipolar, e por reduzido trabalho secundário, que eram usadas para raspar, cortar, perfurar (Wüst, 1990: 347-8, 1992). Uma seqüência estratigráfica que apresenta indústria lítica na base, com instrumentos líticos semi-polidos e polidos em superfície juntamente com alguns fragmentos cerâmicos, são tomados pela autora como evidência de transição para o estágio agrícola (1990).

Wust (1990), comenta ainda sobre as diferenças nos atributos que indicam mudanças significativas ao longo do tempo, especialmente no que diz respeito ao 
repertório lítico dos sítios do período da transição para o período cerâmico. Figuram entre estas variações uma mudança significativa na escolha das matérias-primas, entre as quais a "calcedônia" recebe atenção especial. Essa maior utilização da "calcedônia" em detrimento de arenito silicificado, poderia expressar não apenas uma maior necessidade de bordos cortantes, mas também uma preocupação em se dispor de implementos que permitissem uma vida útil maior. Nesse sentido, a elevada proporção entre lascas brutas e instrumentos sobre lascas, remeteria a um aproveitamento maximizador das matérias-primas, eventualmente relacionado a um maior tempo de permanência e a uma certa rarefação da mesma diante de sua exploração por contingentes populacionais mais numerosos.

Ao redor da era cristã aparecem nesta região as primeiras cerâmicas, que apresentam uma certa semelhança com a cerâmica arqueológica conhecida como tradição Una, a cerâmica mais antiga registrada no Brasil Central.

A cerâmica Una, a despeito de variações locais, caracteriza-se como uma cerâmica simples, de uso presumivelmente utilitário, de acabamento alisado e sem decoração. As vasilhas, sempre de pequenas dimensões, não apresentam formas especializadas (Schmitz et al., 1989; Prous, 1992). Wüst (1990) a descreve como uma cerâmica de caráter utilitário, "predominantemente lisa, e os recipientes cerâmicos são pequenos ou médios, predominando bordas diretas, sendo os com contorno infletido relativamente raros. As formas básicas abrangem recipientes globulares e cônicos, tigelas rasas e potes com gargalo". A espessura das paredes fica entre 4 e $10 \mathrm{~cm}$ e a coloração da superfície em preto, marrom e cinza. Esporadicamente apresenta um banho vermelho e, num período mais tardio, alguma decoração plástica.

Segundo Prous (1992) esta cerâmica pode ser tomada como uma espécie de indicativo da transição de um sistema de subsistência baseado na caça e coleta para um sistema baseado na agricultura. Apresenta, em alguns casos, restos vegetais associados, inclusive o de algumas plantas cultivadas, como o milho, a cabaça e o amendoim.

Fragmentos dessa cerâmica aparecem geralmente em pequenas quantidades em abrigos rochosos no Rio de Janeiro, Minas Gerais, Goiás e Espírito Santo (Prous, 1992).

$\mathrm{Na}$ bacia do São Lourenço, em abrigos-sob-rocha localizados em áreas de transição entre cerrado e mata, aparece uma cerâmica que tem sido associada à cerâmica Una. A baixa densidade do refugo e as dimensões das áreas de habitação sugerem pequenas comunidades locais, e baixa densidade demográfica (Wüst, 1990:64). 
Num período mais recente, de 900 dC até o século XVIII, a região é ocupada por grupos agricultores ceramistas. Seus vestígios ocorrem em grandes sítios a céu aberto implantados em áreas de cerrado, nas proximidades de grandes rios e de suas matas ciliares. Esses sítios corresponderiam a grandes aldeias anulares de diâmetros de até 500 metros, com as unidades residenciais dispostas em até 3 anéis concêntricos. As camadas arqueológicas dos sítios são pouco espessas, de até $30 \mathrm{~cm}$, sugerindo brevidade na ocupação. Segundo Wust (1990), o aparecimento destas grandes aldeias anulares parece ocorrer de forma relativamente súbita, fato que é usualmente interpretado em termos de ondas migratórias. Tanto em Minas Gerais, como no Mato Grosso, os implementos líticos lascados não parecem sofrer mudanças significativas com o advento da cerâmica ou o surgimento dos grupos agricultores, de modo que a hipótese de uma continuidade étnica parece até então, mais plausívelque aquela de um intenso processo migratório (Wust, 1990).

No entanto, a autora aponta algumas tendências de mudança na indústria lítica dos grupos ceramistas agricultores em relação à indústria lítica dos grupos anteriores tais como: utilização preferencial da "calcedônia", basalto e granito nos sítios cerâmicos, enquanto nos sítios líticos e lito-cerâmicos a matéria-prima por excelência é o arenito silicificado; diminuição do trabalho secundário e do lascamento bifacial; diversificação das categorias de implementos líticos com um rol de instrumentos sobre blocos; diminuição da proporção de lascas e instrumentos sobre lascas em relação a instrumentos sobre núcleos; diminuição de tamanho e número de implementos destinados a cortar e aumento daqueles destinados a raspar, inclusive aumentando-lhes a eficiência através do aumento dos bordos ativos e de seus ângulos de inclinação, e por fim, circulação de artefatos líticos por meio de redes extra-regionais e presença de artefatos líticos que poderiam ser associados à diferenciação de status.

Por sua vez, a cerâmica Uru caracteriza-se pela presença de assadores e tigelas de bases planas e paredes infletidas, ocasionalmente reforçadas, e grandes jarros. $\mathrm{O}$ antiplástico predominante é o cariapé, constituído por cinzas silicosas de espécies vegetais. A decoração é quase ausente, restringindo-se a alguns apêndices e a uma ocasional decoração plástica incisa, além do engobo vermelho.

Essas características da cerâmica Uru sugerem populações grandes que praticariam o plantio principalmente da mandioca. Alguns sítios apresentam materiais intrusivos (por ex., cerâmica temperada com cauixi), sugerindo redes de troca, nas quais 
nem todas as unidades habitacionais estariam envolvidas. Diferenças na distribuição espacial dos vestígios indicam uma certa divisão de trabalho entre unidades residenciais no processamento da mandioca. Diferenças no tamanho e morfologia dos sítios sugerem ainda uma hierarquia fluida entre assentamentos, não tendo apresentado evidências de centralização de poder (Wüst, 1999).

Estudos realizados no vale do São Lourenço (Wüst, 1990) e vale do Araguaia (Robrahn-González, 1996) demonstram que os ceramistas que produziram a cerâmica Uru, entre os séculos X e XVIII estariam envolvidos em processos de fusão cultural com outros grupos, a saber: os Bororo do São Lourenço, e os responsáveis pela cerâmica Aratu no Araguaia.

A presença, de descoberta recente, da cerâmica Uru na faixa interfluvial Paraguai-Guaporé, que envolve outros contextos culturais, pode estar indicando que deslocamentos e processos de fusão se deram de uma maneira ainda muito mais ampla, por parte desses ceramistas.

A partir do século XIII dá-se a ocupação dos vales principais da Bacia do São Lourenço, com acesso a recursos aquáticos e solos mais férteis. Entre o final do século XIII e início do XIV, parece ter havido a adoção de estratégias defensivas, provavelmente devido a pressões externas. Indicadores de tal situação na região do rio Vermelho/São Lourenço foram registrados por Wüst (1990): a presença de um sítio no topo de um morro testemunho, de difícil acesso, e a presença de cerâmica tupiguarani em pequenos sítios, e mais tarde, como material intrusivo, em assentamentos Bororo do período histórico.

A primeira aldeia Bororo na Bacia do rio Vermelho teria sido a aldeia Arigao Bororo, referida pela mitologia daquele grupo, e identificada arqueologicamente por Wüst (sítio arqueológico MT-SL-11). Data de 1.660 da era atual. Os estudos e levantamentos da arqueóloga no território original Bororo identificaram um padrão para essa ocupação semelhante ao dos ceramistas Uru, e é descrito como: assentamentos de morfologia anular, com ocupação linear exclusivamente ao longo dos maiores cursos d'água e de alta piscosidade, em áreas de solos férteis. Os artefatos líticos e cerâmicos, porém, são distintos daqueles da tradição Uru. 
Nos artefatos líticos ocorre uma presença mais acentuada de artefatos sobre seixo e sobre bloco do que nas demais indústrias. Registram-se também implementos elaborados a partir de materiais neobrasileiros, a exemplo do vidro (Wüst, 1990).

Uma caracterização da tradição ceramista Bororo é fornecida pela autora. A confecção dessa cerâmica seria tarefa feminina, sua técnica de manufatura é a acordelada, com roletes de largura entre 1,5 e $5 \mathrm{~cm}$. As bases e talvez pequenas vasilhas são modeladas. Apresenta antiplástico quase exclusivamente de cariapé (96,75\% dos fragmentos), aparecendo ainda uma baixíssima porcentagem de antiplásticos de caco moído, de areia e de misturas.

Levando em conta essa composição de elementos arqueológicos, características ambientais, dados etno-históricos e ainda a visão êmica Bororo, a arqueóloga propõe que na emergência ou surgimento do grupo Bororo, teria havido uma fusão entre grupos de cultura material diversa, com incorporação dos ceramistas Uru à sociedade Bororo (Wüst 1990).

O programa Pré-História e Paleoambiente no Mato Grosso, desde 1983, localizou no município de Rondonópolis, estado de Mato Grosso, cerca de sessenta abrigos-sob-rocha com presença de material lítico e cerâmico e, especialmente, com presença de pinturas rupestres. Alguns desses abrigos apresentam gravuras sobrepostas às pinturas, evidência de sua posteridade em relação às primeiras.

\subsection{A Área em Estudo: Características Gerais}

A região então conhecida como "Cidade de Pedra", conforme já dito, vem sendo pesquisada desde 1983, sua exuberante paisagem, formada por um relevo escarpado em rochas areníticas é o produto de milhões de anos sob a ação dos agentes geológicos, que lhe conferiu um aspecto ruiniforme, que apesar de ser, até certo ponto, comum em rochas areníticas, configurou um relevo tão peculiar, permitindo passagem por entre seus morros de forma cônica. Associado a essa paisagem encontra-se uma série de vestígios humanos, os grafismos rupestres, especialmente, dão notoriedade a essas ocupações, estes estão distribuídos em vários pontos da área e são representados no número de 50 sítios arqueológicos.

O relevo da região foi ao longo dessas últimas três décadas, uma proteção natural visto que, tornava imprópria a sua utilização econômica devido ao seu 
acidentado relevo, dessa forma, as fazendas que ali se estabeleceram não utilizaram da área para plantação de soja e algodão, tão pouco para a agropecuária. Felizmente, em uma iniciativa louvável os responsáveis pela área onde se encontra a "Cidade de Pedra", transformaram o local em uma Reserva Particular do Patrimônio Natural (RPPN) que constitui o "Parque Ecológico João Basso", com cerca de $44.000 \mathrm{~km}^{2}$. Está situada às margens do rio Vermelho sob as coordenadas latitude sul:16²9'-33' e longitude oeste: $54^{\circ} 48^{\prime}-55^{\prime}$.

Apesar de formar uma unidade coerente, a área compreende diferentes feições de relevo, microbacias e vegetações, sendo a mais evidente delas, a distinção entre as ocupações situadas nos degraus das formações areníticas e nas áreas mais baixas, na planície do rio Vermelho, que por sua vez estão associadas a diferentes ocupações, em abrigo e a céu aberto (Vilhena Vialou e Vialou, 2000,2003).

Dentre os cinqüenta sítios em abrigo sob rocha e cavernas com representações rupestres que foram identificados e estudados, cinco deles, foram ou estão sendo escavados, são os abrigos: Ferraz Egreja, Vermelhos e Arqueiros; e as cavernas Cipó e Antiqueira.

Os demais abrigos rupestres não são propícios a moradias, seja por sua localização, ora em áreas escarpadas, ora em nichos ou alcovas reduzidas, pode ocorrer também que em abrigos cujas instalações poderiam ser mais propícias não ocorre formação de solo ou de sedimentação nos abrigos de forma que o piso do abrigo é a própria rocha, nesses casos, possíveis registros de breves instalações não se conservaram. Por outro lado, quando os abrigos rupestres possuem sedimento, as verificações de instalações, mesmo que sumárias, foram detectadas por algumas sondagens, através de fragmentos cerâmicos, carvões de fogueira, hematitas e algumas lascas, exemplos desses sítios são: Capivara, Carimbos, Falha e Pacífico (Vialou e Vilhena Vialou, 1999, 2000, 2003).

Dos sítios a céu aberto, cinco foram registrados e quatro estão sendo escavados: Baia 58, Fazendinha, Turbina e Jatobá. A exceção do sítio Fazendinha, que está implantado na margem do rio Vermelho, os outros sítios têm sua localização mais próxima às drenagens que atravessam a Cidade de Pedra, através das quais se ligam aos sítios em abrigo.

Os sítios cuja matéria-prima lítica é objeto desse estudo, ocorrem em abrigos (Ferraz Egreja, Vermelhos e Arqueiros), em cavernas (Antiqueira e Cipó), e a céu 
aberto (Turbina e Fazendinha). Estes encontram-se em fases diferentes no que se refere ao andamento das escavações, sendo que apenas o sítio Abrigo Vermelhos teve os trabalhos encerrados.

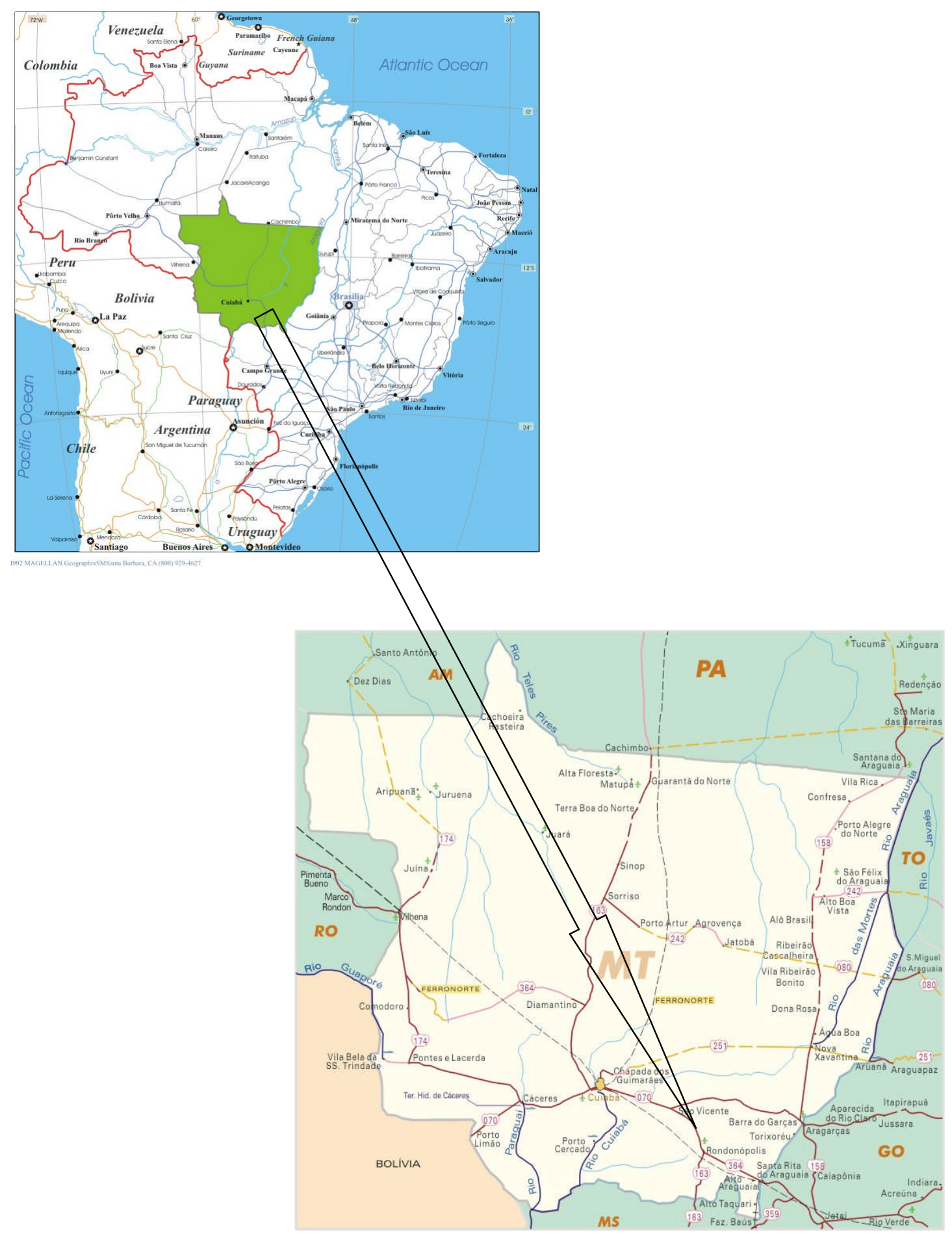

Figura 1. Localização do município de Rondonópolis, onde se realizam as pesquisas. 


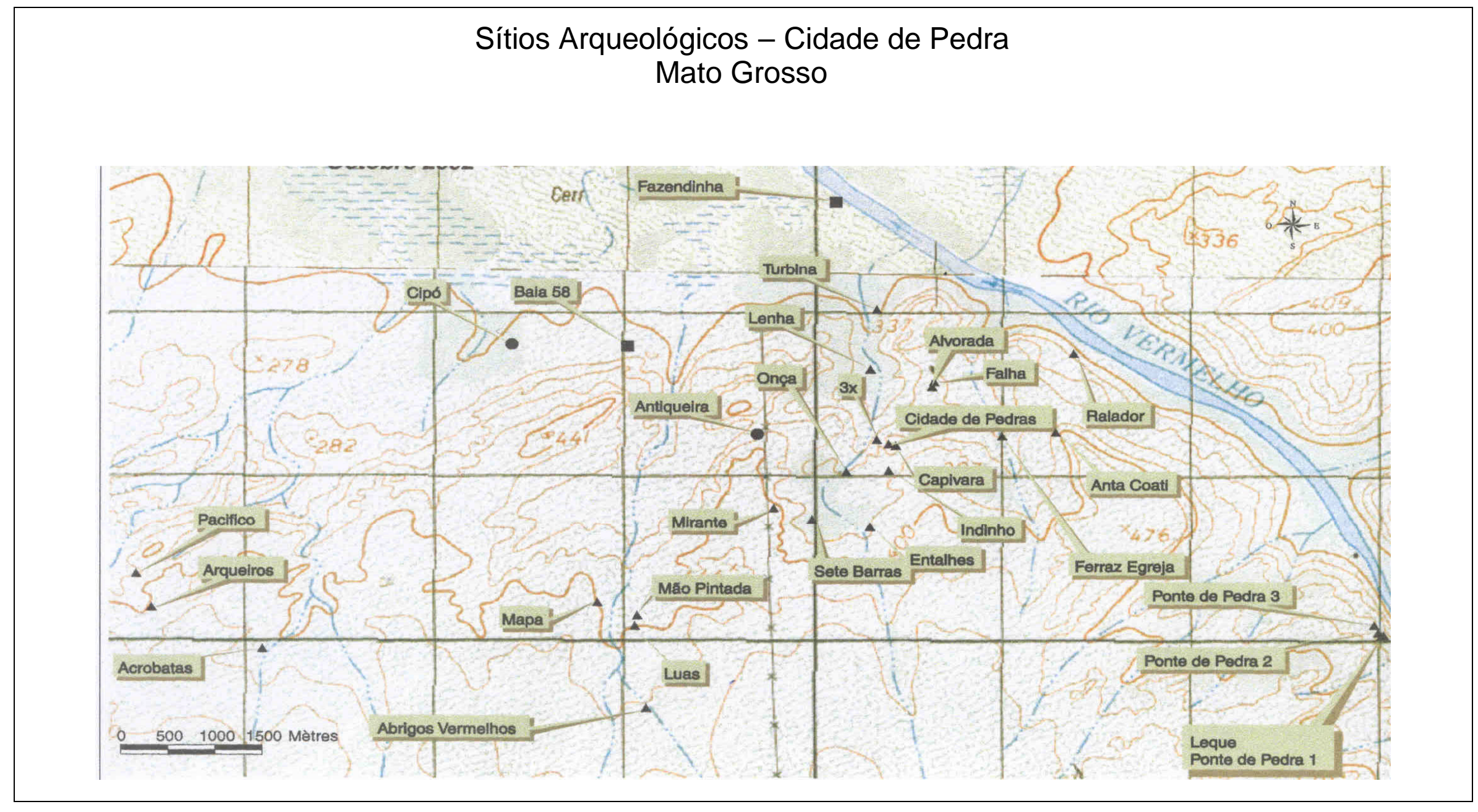

Figura 2. Localização dos Sítios Arqueológicos na Cidade de Pedra (Concepção: J-R Houller e T. Arnoux, 2002-2003) 


\section{Sítio Arqueológico Ferraz Egreja}

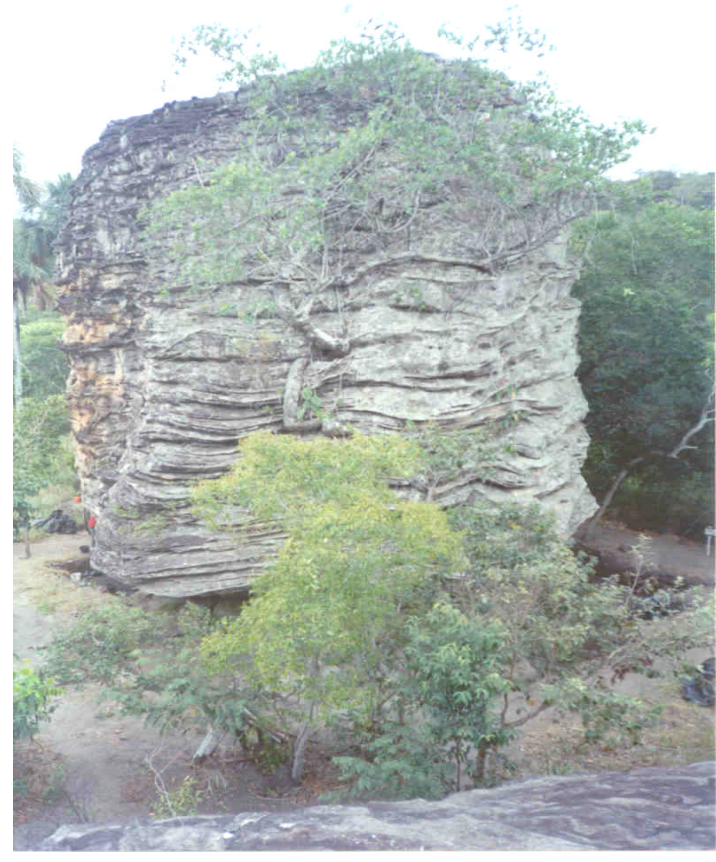

3. Vista do sítio

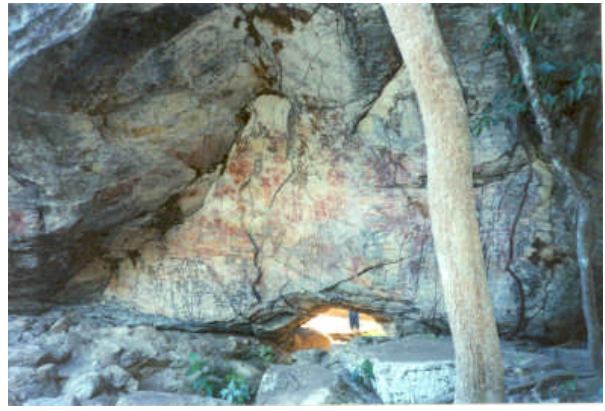

4. Detalhe do interior do abrigo

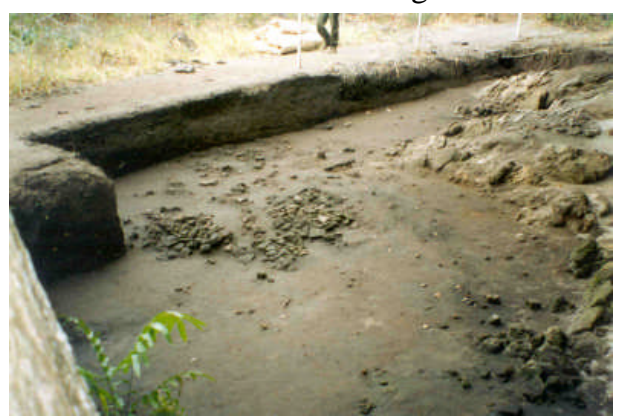

5. Detalhe da escavação

\section{Sítio Arqueológico Caverna do Cipó}

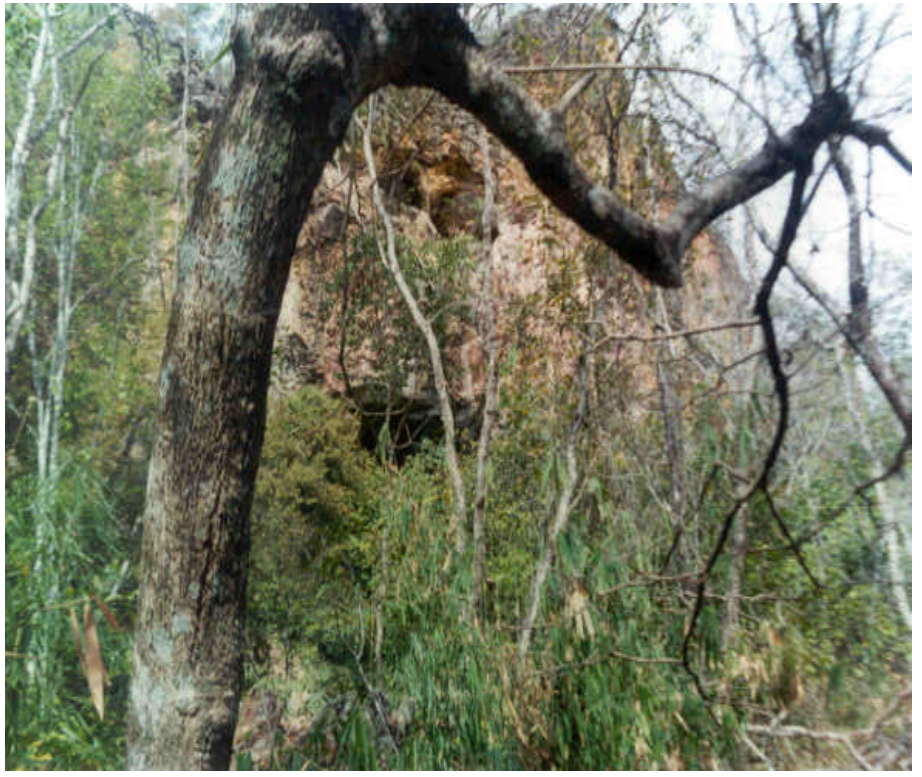

6. Vista da entrada da cavernao

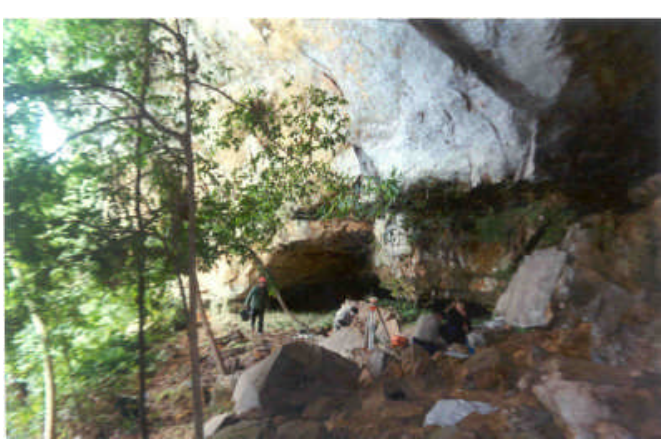

7. Detalhe da escavação

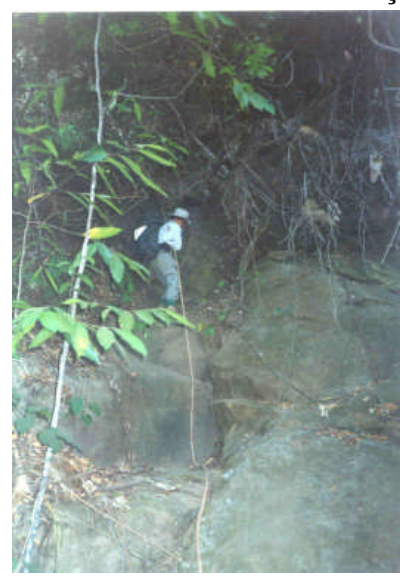




\section{Sítio Arqueológico Antiqueira}
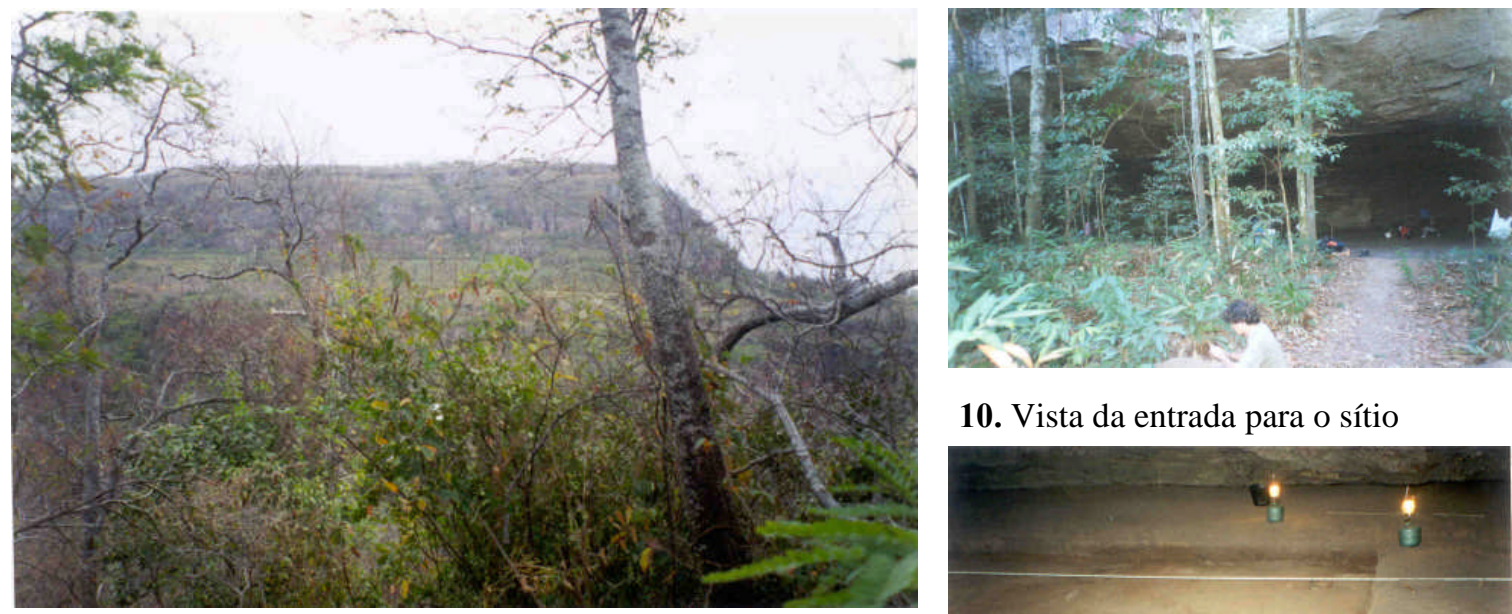

10. Vista da entrada para o sítio

9. Vista do relevo no qual a caverna está inserida

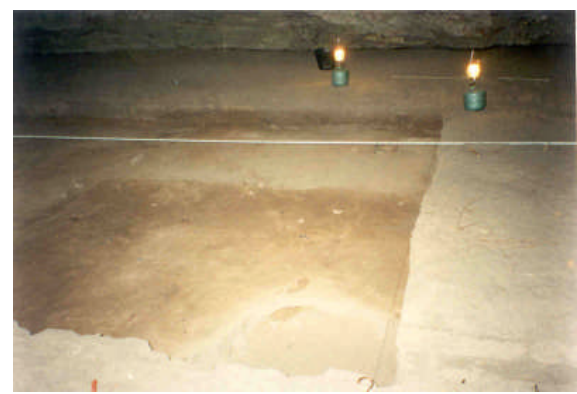

11. Detalhe das escavações- 2002

\section{Sítio Arqueológico Arqueiros}

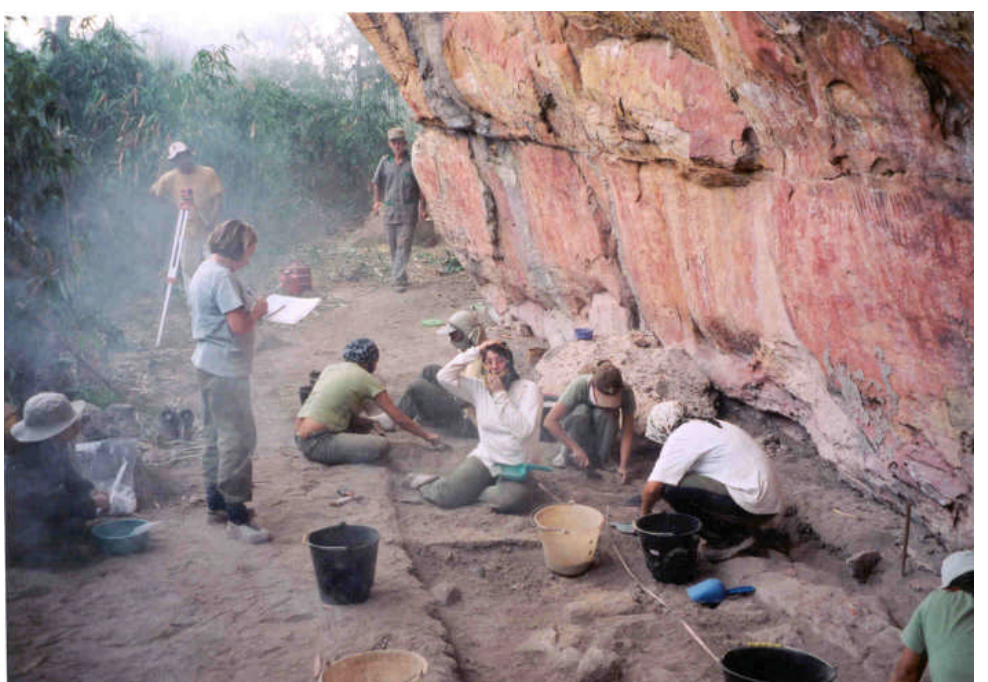

12. Detalhe das escavações - 2003

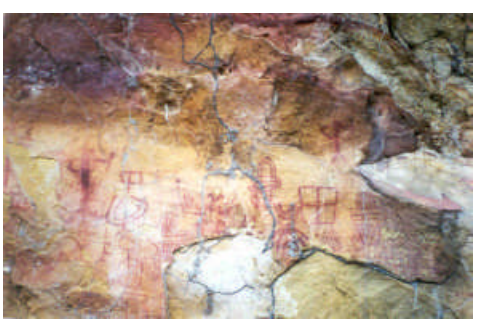

13. Detalhe da arte rupestre

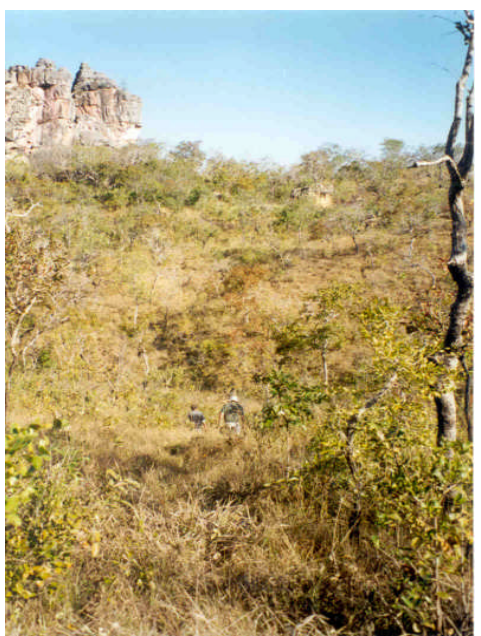

14. Vista da trilha para o sítio 
Sítio Arqueológico Fazendinha

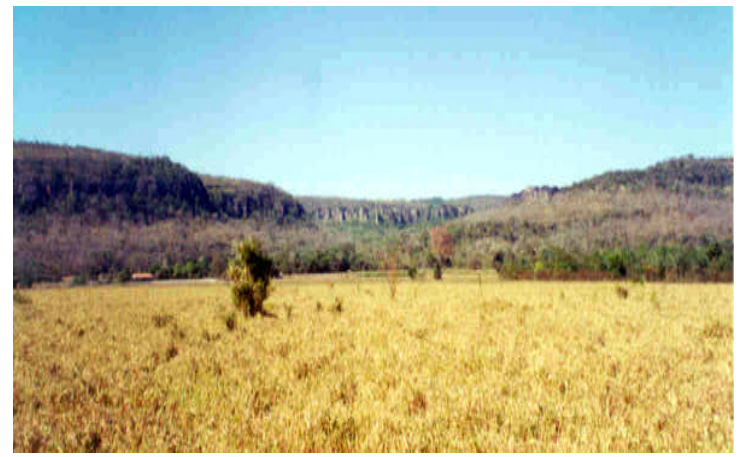

15. Vista do sítio

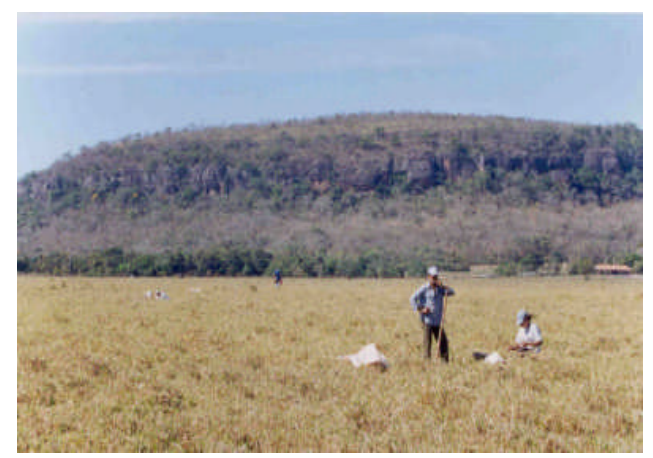

16. Vista do sítio sob outro ângulo

\section{Sítio Arqueológico Turbina}

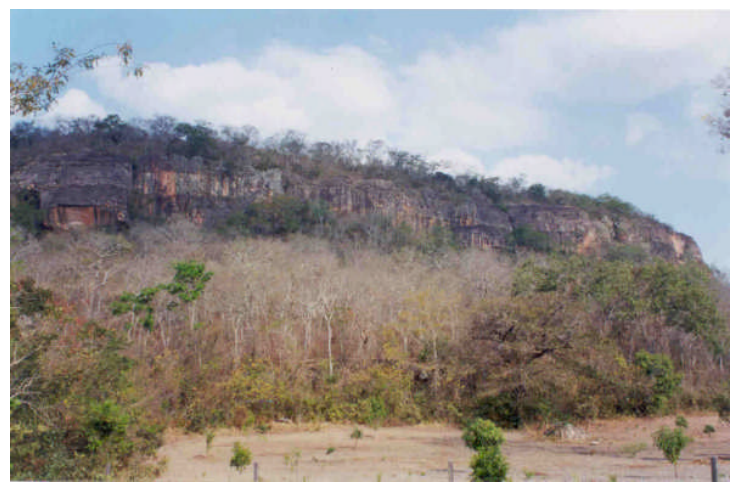

17. Vista parcial do sítio 


\section{Capítulo 3}

\section{Caracterização Petrográfica da Matéria-Prima Lítica}

A questão do espaço freqüentado para coleta de matéria-prima lítica, envolve uma compreensão sistemática do material encontrado nos sítios arqueológicos e da litologia da área circundante. Para isso, se faz necessário uma descrição petrográfica, no sentido de estabelecer limitações em sua ocorrência.

Muito da classificação aqui proposta se ateve ao plano estrutural macroscópico. Luedtke (1979 apud Araújo, 1991) frisa a imprecisão decorrente da simples observação macroscópica para fins de classificação e estabelecimento de áreas-fonte de matériaprima lítica (especialmente silexitos), mas reconhece que a diferenciação visual é primordial para um início de trabalho, e mesmo porque, é o método que menos requer tempo e aparelhagem para ser levado a cabo.

O material de sete sítios arqueológicos foi analisado, são eles: os abrigos, Ferraz Egreja, Vermelhos e Arqueiros; as cavernas, Antiqueira e Cipó e o sítio a céu aberto, Fazendinha. Nesses sítios, dois grandes grupos de rochas estão presentes: rochas sedimentares e rochas metamórficas, além de minerais como o quartzo e a hematita.

\subsection{Rochas Sedimentares}

Essas rochas são formadas por partículas minerais transportadas e depositadas por água, vento ou gelo, que resultaram da precipitação química ou foram formadas por ação biogênica, como as acumulações de matérias orgânicas. São fundamentalmente constituídas por três componentes que podem aparecer misturados em todas as proporções: os terrígenos, os aloquímicos e os ortoquímicos (Glossário Geológico/IBGE, 1999). 


\subsubsection{Arenitos}

Arenito é um termo descritivo para designar um sedimento clástico litificado, com os constituintes granulares apresentando diâmetro médio de tamanho areia, sem conotação mineralógica ou genética (Glossário Geológico/IBGE, 1999).

A litificação é o processo através do qual um sedimento inconsolidado transforma-se em rocha endurecida, trata-se de um processo diagenético que da origem a uma textura que resulta das modificações pós-deposicionais com formação de precipitados químicos e alterações dos elementos do arcabouço, e inclui, entre outras propriedades, compactação e cimentação. A compactação causa a eliminação ou grande redução dos poros das rochas por rotação e deformação dos grãos, a cimentação, por sua vez, ocasiona o material que une os grãos de uma rocha sedimentar, através da precipitação química de soluções intersticiais, podendo destacar-se a sílica, o carbonato de cálcio e os óxidos de ferro, assim sendo, a silicificação é uma cimentação feita por sílica. Essa cimentação poderá variar resultando em diferentes graus de coesão entre os grãos.

O termo grau é aqui adotado, num sentido relativo como referência às condições de cimentação a que a rocha foi submetida, considerando apenas o conjunto litológico da área em estudo, baseando-se principalmente nos aspectos texturais macroscópicos.

Dessa forma, quatro graus podem ser definidos:

- Grau 1 (Ar-1)

São arenitos de silicificação muito incipiente, apresentam uma certa friabilidade.

- Grau $2(\mathrm{Ar}-2)$

São arenitos de silicificação "intermediária" pois o preenchimento dos poros da rocha não é total, parte dos grãos é visivelmente isolados proporcionando uma textura grosseira.

- Grau $3(\operatorname{Ar}-3)$

São arenitos de boa silicificação. Não apresentam friabilidade, e têm uma textura lisa, devido ao preenchimento dos poros. É possível a visualização dos grãos envoltos numa matriz silicosa. 
Contudo os arenitos de grau 3 estão relacionados a áreas de fraturamento/diaclasamento que ocorrem nas formações areníticas Furnas e Ponta Grossa, portanto correspondem a processos diagenéticos vinculados a um baixo grau de metamorfismo.

Outra característica considerada é a cor da rocha, por se tratar de um dos elementos que mais chamam a atenção, especialmente nas rochas sedimentares.

A cor do sedimento pode ser primária (original ou singenética) ou secundária (epigenética), a cor primária é a existente na época do soterramento dos sedimentos e a secundária, a que resulta das mudanças ocorridas subseqüentemente ao soterramento e pode ser ditada por fenômenos ligados principalmente aos processos intempéricos determinados pelos minerais secundários. Nesse caso, as rochas são submetidas à oxidação e hidratação, podendo ocorrer também introdução ou eliminação de compostos (Suguio, 1980).

Os minerais sedimentares de ferro são os mais comuns e são caracterizados por certas cores, bastante característica nos arenitos das Formações Furnas e Ponta Grossa, presentes na área em estudo. Essas cores, resultantes de compostos de ferro podem ser resumidas da seguinte maneira (Maccarthy, 1926 apud Suguio, 1980):

- Hematita $\left(\mathrm{Fe}_{2} \mathrm{O}_{3}\right)$ : vermelha a púrpura, cinza;

- $\quad$ Goethita $\left(\mathrm{Fe}_{2} \mathrm{O}_{3} \cdot \mathrm{nH}_{2} \mathrm{O}\right)$ : amarela, castanha;

- Lepidocrocita (FeO. $\left.\mathrm{mH}_{2} \mathrm{O}\right)$ : vermelha, laranja, castanha;

- Limonita: denominação para uma mistura de hidróxidos de ferro não identificados individualmente, cujas cores variam em tons de laranja a amarelo.

As cores que aparecem em forma de manchas, acompanhando fraturas ou poros, e que não se modificam de acordo com as variações litológicas certamente são de origem secundária (Suguio, 1980)

No arenito podem ocorrer concentrações desses minerais de óxido de ferro, em especial a hematita, essas concentrações são observadas principalmente na área próxima 
a Ferraz Egreja, onde são encontrados fragmentos de arenito extremamente enriquecidos em ferro e cujo trabalho pela água lhe concedeu formas arredondadas, mas pouco esféricas. Esse material é freqüentemente encontrado nos sítios arqueológicos com marcas que deixam clara a sua utilização como matéria-prima corante. Essas concentrações de ferro ocorrem também formando pequenas concreções e nódulos, que podem formar carapaças ferruginosas sobre o arenito, sendo esse material freqüentemente transportado naturalmente com o sedimento.

Além da composição da rocha e dos corantes principais, vários outros fatores influem na cor final do sedimento, Twenhofel (1932 apud Suguio 1980) e Pettijohn (1957) consideram que a granulometria das rochas é também um fator importante. Ocorre uma tendência para as cores serem mais escuras em rochas de granulometria mais fina. $\mathrm{O}$ mesmo ocorre em relação à silicificação, rochas de granulometria mais fina tendem a parecer melhor silicificadas, os poros são menores pois, os grãos pequenos permitem o seu preenchimento na compactação.

Essas três características, silicificação, granulometria e cor, determinaram a análise do material lítico em rochas areníticas na tentativa da formulação dos conjuntos litológicos diretamente relacionados à fonte de matéria-prima, no entanto, a análise de laboratório só se tornou totalmente compreensível após a caracterização geológica da área, revelando que a associação de mesmas cores ou graus de silicificação não eram suficiente para uma classificação que tivesse como objetivo a fonte de matéria-prima. Sendo assim, buscou-se primeiro a identificação da associação das variáveis dessas três características na litologia regional através das prospecções geológicas, para que então fosse possível identificar essa heterogeneidade no material lítico analisado em laboratório e atribuí-la a um determinado contexto litológico.

\subsubsection{Silexitos}

O termo silexito é aqui utilizado de acordo com a classificação adotada por Araújo (1991), que utiliza a expressão para designar genericamente as rochas silicosas de gênese química sensu latu. 
Devido aos diferentes modos de formação e ocorrência, bem como aos vários tipos de impurezas associadas, os silexitos podem apresentar aspectos variados e as mais diversas cores podendo ser subdivididos em grupos estruturais que levam em conta estruturas observáveis a olho nu: Silexitos maciços, bandados, nodulares, brechóides, oolíticos, fossilíferos e estromatolíticos.

Os silexitos com ocorrência na área são:

- Silexitos maciços: via de regra, são compactos não apresentando qualquer feição de descontinuidade, ocorre nas variedades sílex e jaspe.

- Silexitos bandados: caracterizam-se por conter descontinuidades a nível macroscópico, com bandamento resultante de maior ou menor grau de impurezas e diferenças granulométricas.

- Silexitos nodulares: apresentam feições estruturais, geralmente reflexos de uma concentração localizadas de impurezas ou de diferenças mineralógicas e texturais. Entende-se por nódulos as manchas variegadas de contornos arredondados e limites difusos.

- $\quad$ Silexitos brechóides: refletem diferenças texturais ou químicas, mostrando contornos abruptos e bem delineados.

- $\quad$ Silexitos oolíticos: são produto da substituição química de sedimentos carbonáticos por sílica, sendo que, no caso, o sedimento original era um calcário oolítico, ou seja, constituído de pequenos corpos concrecionais de forma arredondada ou ovalada, diâmetro variando entre 0,25 e $2 \mathrm{~mm}$. A sílica, ao substituir o carbonato, tende a preservar as formas dos oólitos.

Apesar da variedade de silexitos encontrada em alguns sítios, eles são agrupados em dois conjuntos de acordo com as duas fontes de matéria-prima, que serão comentadas no próximo capítulo. 


\subsection{Rochas Metamórficas}

São formadas a partir do processo de metamorfismo que envolve transformações em resposta às novas condições. Uma rocha originalmente formada em uma ambiente ígneo ou sedimentar recristaliza para produzir uma rocha metamórfica. A maioria das rochas metamórficas retém algumas das características do material original, tais como composição química global ou feições maiores, tipo de acamamento, enquanto são desenvolvidas novas texturas e, freqüentemente, novos minerais (Yardley, 1989).

\subsubsection{Quartzitos}

Os quartzitos diferem dos arenitos silicificados por corresponderem a rochas constituídas essencialmente de quartzo recristalizado, ao qual comumente se associam micas brancas resultante de um grau metamórfico que vai de médio a forte.

Essas rochas estão associadas aos planos de fratura/diaclasamento encontrados na área, a forma irregular com que ocorre nos afloramenos compõe um verdadeiro mosaico com os arenitos, característica de certa forma comum em rochas associadas a diaclasamentos.

\subsubsection{Rochas Metamórficas - "Rochas Verdes"}

Este conjunto agrupa as rochas que se convencionou denominar nas escavações como "rocha verde".

Macroscopicamente essas rochas são facilmente identificáveis enquanto conjunto, independente da sua denominação. Nos sítios arqueológicos ela pode se apresentar nas seguintes formas:

- $\quad$ em uma forma friável, compacta, sem planos de foliação ${ }^{1}$, com cores esverdeadas e tons amarelados; 
- podem também ocorrer nessas mesmas cores porém, apresentando planos de xistosidade, claramente associados a processos de metamorfismo, a granulometria pode variar de areia grossa a silte, lembrando filito ${ }^{2}$;

- em uma terceira composição estas rochas ocorrem bastante compactas e coesas, dura como um arenito silicificado, mas com granulometria média a grossa com cores mais escuras, verde escura a preta, lembrando claramente, a olho nu, uma rocha ígnea básica.

Para a identificação da área fonte deste material foi importante saber o mais precisamente do que se tratava. Para tanto, foram confeccionadas lâminas petrográficas de um fragmento friável do sítio Ferraz Egreja e um fragmento compacto de cor enegrecida do sítio Fazendinha a fim de compará-las com possíveis áreas fontes que até então não haviam sido localizadas.

Os resultados obtidos através da análise microscópica foram que as rochas mais friáveis e compactas do sítio Ferraz Egreja tinham a mesma composição mineralógica das rochas mais compactas de cores enegrecidas. São constituídas, mineralogicamente, por quartzos, filossilicatos (sericita, biotita e muscovita), plagioclásios, epidoto, zircão e turmalina.

A biotita pode ser vista soldando os cristais de quartzo. Trata-se de um arcabouço sustentado mais por cristais que pela matriz, constituindo, praticamente, um agregado de cristais sem retrabalhamento. Não é uma rocha sedimentar e há dificuldades em se afirmar que se trata de uma rocha ígnea. Sua petrográfica sugere metamorfismo, um dos indícios é a identificação de recristalização de alguns cristais por aumento de temperatura, o que poderia estar sugerindo um metamorfismo de contato, mas o protólito não foi determinado, portanto não foi definida uma nomenclatura para esta rocha, mas sua fonte foi encontrada como será visto no próximo capítulo.

\footnotetext{
${ }^{1}$ Termo aplicável para todas as feições planares das rochas metamórficas (Hobbs, Meons \& Williams, 1976)

${ }^{2}$ Rocha xistosa de granulação fina resultado da ação de grau metamórfico mais elevado do que a ardósia. A superfície de xistosidade tem um aspecto lustroso devido ao desenvolvimento de clorita ou sericita. Grau metamórfico fraco.
} 
Através destas análises petrográficas, observou-se que o tom esverdeado a amarelado que essas rochas adquirem são produto de alteração pelo tempo em que estiveram inseridas no sedimento, isso pôde ser observado quando o fragmento foi serrado para confecção da lâmina. Observou-se que a cor da "rocha verde" era muito mais escura, ou seja, a cor verde da rocha é na verdade o produto da alteração dos filossilicatos que tendem a gerar tons esverdeados, dando um aspecto superficialmente friável, em consequiência de uma lixiviação do cimento que une os grãos de quartzo. Esse dado informou que quando essas rochas foram retiradas da área fonte, deviam apresentar uma forma mais coesa, mais resistente, além de uma cor mais escura. Em consequiência de alterações físico-químicas, elas podem ter aspectos diferentes mas, são uma única rocha.

Em um primeiro momento, ao se analisar a lâmina petrográfica sem saber sobre o seu afloramento, esta rocha poderia ser comparada às rochas vulcanoclásticas do norte do Estado do Mato Grosso. Porém, por se tratar de um material encontrado com uma relativa abundância nos sítios arqueológicos, e, como tudo indica não se tratar de material da Bacia do Paraná, levantou-se a hipótese de que haveria um pacote vulcanoclástico inserido dentro do Grupo Cuiabá $^{3}$ que estaria gerando um metamorfismo de contato, evento, ainda não descrito na região, podendo ser ainda, alguma variação da ação do metamorfismo do Grupo Cuiabá no pacote sedimentar, ou seja, de uma maneira ou de outra, a área fonte seria algo com abrangência limitada.

No entanto, a análise das rochas mais foliadas demonstrou que elas não têm a mesma petrográfia e nem a mesma estrutura das rochas mais compactas. Elas são constituídas, basicamente, por quartzo e sericita e são muito xistosas, fato que estaria indicando um metamorfismo dinamotermal de baixa temperatura.

Como há mais de $15 \%$ de grauvaca, essa rocha pode ser chamada quartzograuvaca. É também, uma rocha presente no sítio, caracterizada principalmente pelos planos de xistosidade ${ }^{4}$.

\footnotetext{
${ }^{3}$ Unidade litoestratigráfica formal de categoria superior à formação. O nome de um grupo deve ser preferencialmente derivado de uma apropriada feição geográfica ou localidade próxima, no caso, a cidade de Cuiabá.

${ }^{4}$ A xistosidade consiste na orientação preferencial de minerais micáceos, segundo as quais as rochas se partem, sob a forma de fatias ou lâminas.
} 
A análise desse conjunto de lâminas permitiu considerar, uma vez que todas as rochas são produto de metamorfismo, supor que poderia estar ocorrendo uma gradação, ou seja, um evento metamórfico de contato que agiria com mais intensidade nas rochas mais próximas (rochas compactas e coesas) e esses reflexos iriam diminuindo conforme fosse se distanciando da área principal do metamorfismo (rochas foliadas). Outro indício de que essas rochas estariam correlacionadas em um único evento geológico é a presença de planos de fratura, que ocorrem tanto nas rochas mais compactas como nas rochas mais foliadas. Essas faces planas, parecem ter sido aproveitadas no polimento da rocha.

\subsection{Minerais}

Elemento ou composto químico de ocorrência natural formado como produto de processos inorgânicos.

\subsubsection{Hematita}

Trata-se de um mineral de ferro com fórmula $\mathrm{Fe}_{2} \mathrm{O}_{3}$, sistema trigonal, que forma cristais cinzentos ou pretos com forte brilho metálico e traço vermelho. Forma massas reniformes e agregados fibrosos em rochas ígneas, metamórficas e sedimentares (Dicionário Geológico/IBGE, 1999).

Está presente nos sítios na forma de seixos, que são na verdade, concentrações de hematita na sua forma diminuta (aspecto pastoso), que se formam a partir do cimento entre os grãos de quartzo do arenito, que se desagregam da rocha e são trabalhados pela água dando origem a seixos corantes, tanto de textura mais síltica como de textura arenosa. Raramente ocorrem na forma de cristais.

Também são comuns os nódulos e concreções, característicos destas formações geológicas. 


\subsubsection{Quartzo}

Mineral do grupo da sílica, com fórmula $\mathrm{SiO}_{2}$, que se apresenta sob as formas de baixa e alta temperatura. Pode-se apresentar com um ampla gama de cores, devido a impurezas, tem dureza 7 na escala de Mohr (Dicionário Geológico/IBGE, 1999). Ocorre nos sítios, principalmente na forma de seixos, mais raramente, enquanto matéria-prima para adornos. 


\section{Capítulo 4}

\section{Caracterização Geológica: Proveniência do Material Lítico Arqueológico}

As prospecções geológicas foram sendo desenvolvidas concomitantemente às análises petrográficas em laboratório do lítico presente nos sítios. Buscava-se entender que relações poderiam ser identificadas através da exploração de recursos minerais, para tanto, algumas questões precisavam ser respondidas:

- Os arenitos com melhor silicificação (Ar-3) e também parte dos silexitos, mais aptos ao lascamento, eram de origem secundária, seu arredondamento e seu córtex de aspecto lustroso indicavam um transporte fluvial, no entanto, na principal drenagem, o rio Vermelho, não se verificam formação de cascalheiras ao menos nos $25 \mathrm{~km}$ tanto para montante como para jusante. Qual era então a área fonte desta rocha amplamente utilizada? As demais drenagens da área? Concentração de seixos em paleodrenagens? Ou ainda, subia-se o rio Vermelho mais de $60 \mathrm{~km}$, em busca cascalheiras, sendo estas no contex to de outras formações geológicas?

- Outros conjuntos de arenito com silicificação mais incipiente e também os quartzitos, estariam indicando uma origem primária através do tamanho e do córtex das peças, no entanto a paisagem da região é composta basicamente por arenitos friáveis da Formação Furnas. Quais seriam então as áreas onde a ação tectônica teria provocado uma silicificação ou recristalização dos arenitos?

- As análises petrográficas mostraram que uma diversidade de rochas metamórficas correspondiam a um mesmo tipo de rocha, a partir da gradação de um mesmo evento geológico, seria mesmo isso? Onde isto estaria acontecendo? 
Para responder a questões como essas, foram realizadas prospecções litológicas com alguns procedimentos de mapeamento geológico: estudo bibliográfico da geologia regional, principalmente através do Projeto Radam Brasil - Folhas SD 21 e SE 21 (1982), Souza et al. (1997), Projeto Primaz - Rondonópolis (1999); estudo fotogeológico através da utilização de fotografias aéreas que, com o auxílio do estereoscópio permitiu a localização das estruturas geológicas (áreas de falhamento/diaclasamento), além da identificação da hidrografia e relevo. Essas informações associadas às cartas planialtimetricas, Folhas Anhumas (SE-21-X-B-V) e Rondonópolis (SE-21-X-B-II), na escala de 1:100 000, permitiram o planejamento da etapa de campo onde foram realizadas coletas de amostras petrográficas com fins de comparação.

\subsection{Prospecção geológica}

As prospecções geológicas foram realizadas em três etapas, na primeira etapa foi feito um reconhecimento geral da área com coletas esporádicas de amostras petrográficas, na segunda etapa foram executados caminhamentos em perfis traçados de maneira a acompanhar as drenagens que cortam a área, pois dessa forma, se poderia fazer uma cobertura das estruturas geológicas com um bom direcionamento. Na terceira etapa de prospecção geológica o conjunto da Cidade de Pedra e adjacências foi extrapolada com a finalidade de comprovar hipóteses levantadas na etapa anterior.

As observações de campo vieram a corroborar os levantamentos geológicos regionais realizados pelo Projeto Radam Brasil (1982) e por Santos et al. (1997), que contextualizam a área no flanco noroeste da Bacia do Paraná, como representada principalmente pelas unidades devonianas, Furnas e Ponta Grossa. Apesar dessas duas formações geológicas comporem grande parte da paisagem na área em estudo, durante a prospecção foi detectada uma outra formação geológica. Trata-se da Formação Vila Maria, que nessa porção noroeste da Bacia do Paraná só havia sido descrita por Borghi \& Moreira (1998) na região de Chapada dos Guimarães, como uma ocorrência inédita de um intervalo estratigráfico do Paleozóico inferior em inconformidade sobre o grupo Cuiabá (Pré-Cambriano) e em discordância sob o grupo Paraná (Devoniano). O reconhecimento desta formação geológica foi baseado no icnofóssil Arthrophicus alleghaniensis, arenitos em camadas tabulares e possivelmente, diamictitos, descritos no artigo de Borghi \& Moreira (1998) e Bergamaschi (1995). 


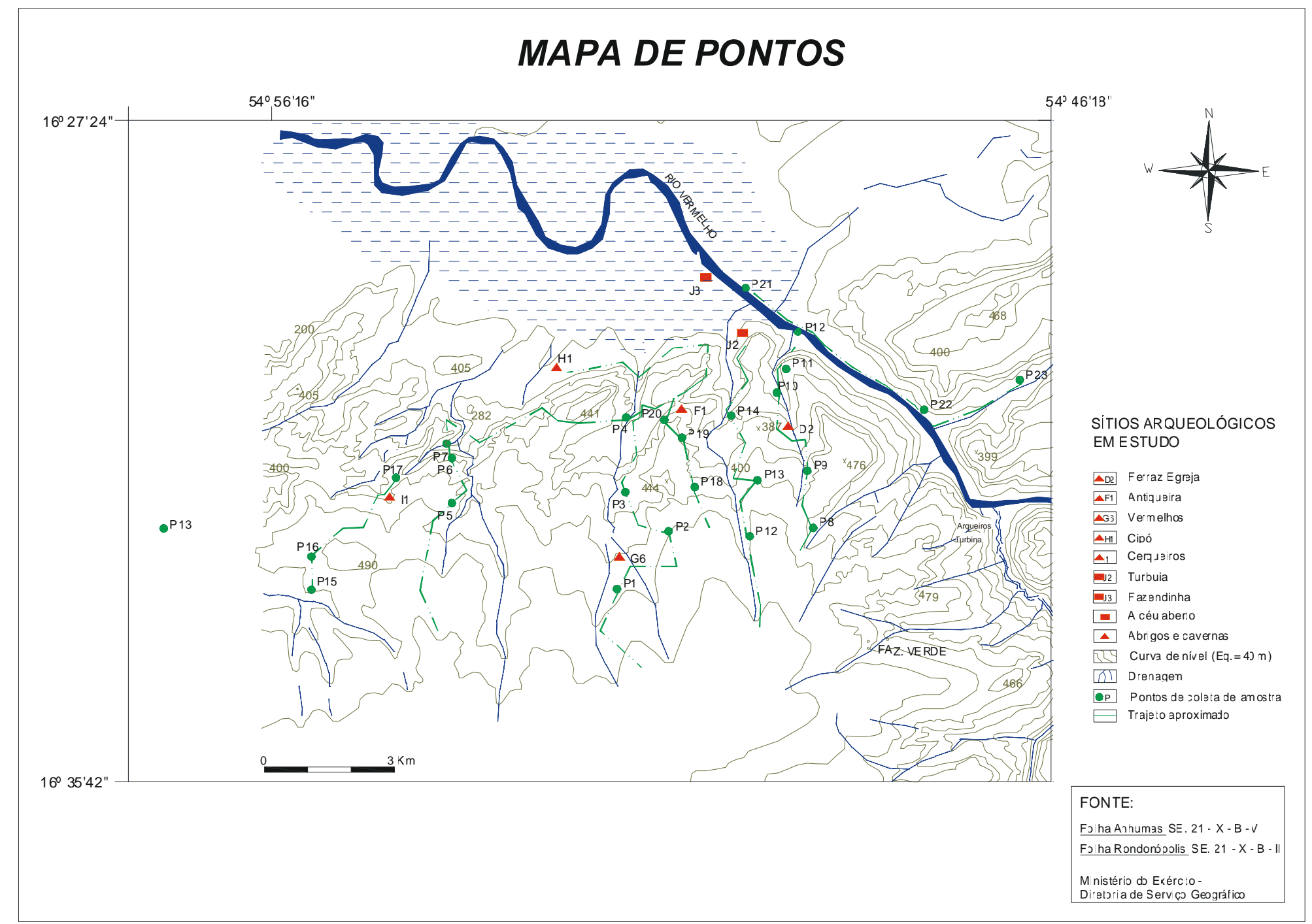

Figura 18. Mapa de pontos - percurso percorrido durante as prospecções 
A definição destas unidades geológicas é de fundamental importância para o entendimento da localização e da forma como as litologias podem ser encontradas. Assim sendo, segue adiante a seguinte descrição para essas formações geológicas:

A Formação Furnas é a principal unidade geológica aflorante na área de estudo, é descrita por Santos et al. (1997) como um pacote expressivo de arenitos médios a grossos que, em direção ao topo, sede lugar a sequiências psamo-pelíticas, representadas por bancos tabulares de areia fina micácea com intercalações de argilas e siltes. Os arenitos são predominantemente quartzosos com variações feldspáticas e ocorrência de impregnações de óxido de ferro. Tem cor cinza esbranquiçada a rósea. No topo da formação, é observada uma seqüência transicional, pouco espessa, com interdigitação de arenitos dominantemente finos a muito finos e siltitos e também folhelhos sílticos de cor cinza azulada a violácea com abundante presença de micas.

A Formação Ponta Grossa ocorre no topo dos relevos tabulares e foi subdividida por Santos et al.(1997) em duas seqüências distintas: pelítica e psamo-pelítica.

A sequiência pelítica composta folhelhos e folhelhos sílticos com intercalações de argilitos na porção basal e siltitos e arenitos muito finos no topo. As rochas micáceas ocorrem em cores variando de amarelo a cinza com tons esverdeados, tem boa fissilidade e laminação plano-paralela.

A sequiência psamo-pelítica, por sua vez, apresenta um espesso pacote de siltitos e arenitos finos a muito finos e argilitos subordinados. Os siltitos que predominam tem cor cinza violácea à esverdeada, bem estratificados, com níveis laminados e maciços.

\subsection{Caracterização geológica e proveniência dos arenitos e silexitos}

Os afloramentos não eram, como supunha anteriormente, extensos. Antes da ida ao campo acreditava, baseando-se em estudos fotogeológicos e bibliografia correspondente, que os falhamentos e diaclasamentos que ocorrem na região em escala regional e de afloramento em duas direções preferenciais: N 60-80 E (estruturas mais antigas e com os arenitos mais silicificados) e N 10-30 W seriam responsáveis por uma abundância de afloramentos alinhados nessa direção. Ao contrário do que ocorre na área urbana de Rondonópolis e adjacências, não há formação dessas linhas continuas de silicificação. Na verdade, o que a ocorrência dessas estruturas gera na área em estudo, é o relevo característico que nomeia a região como "Cidade de Pedra". 


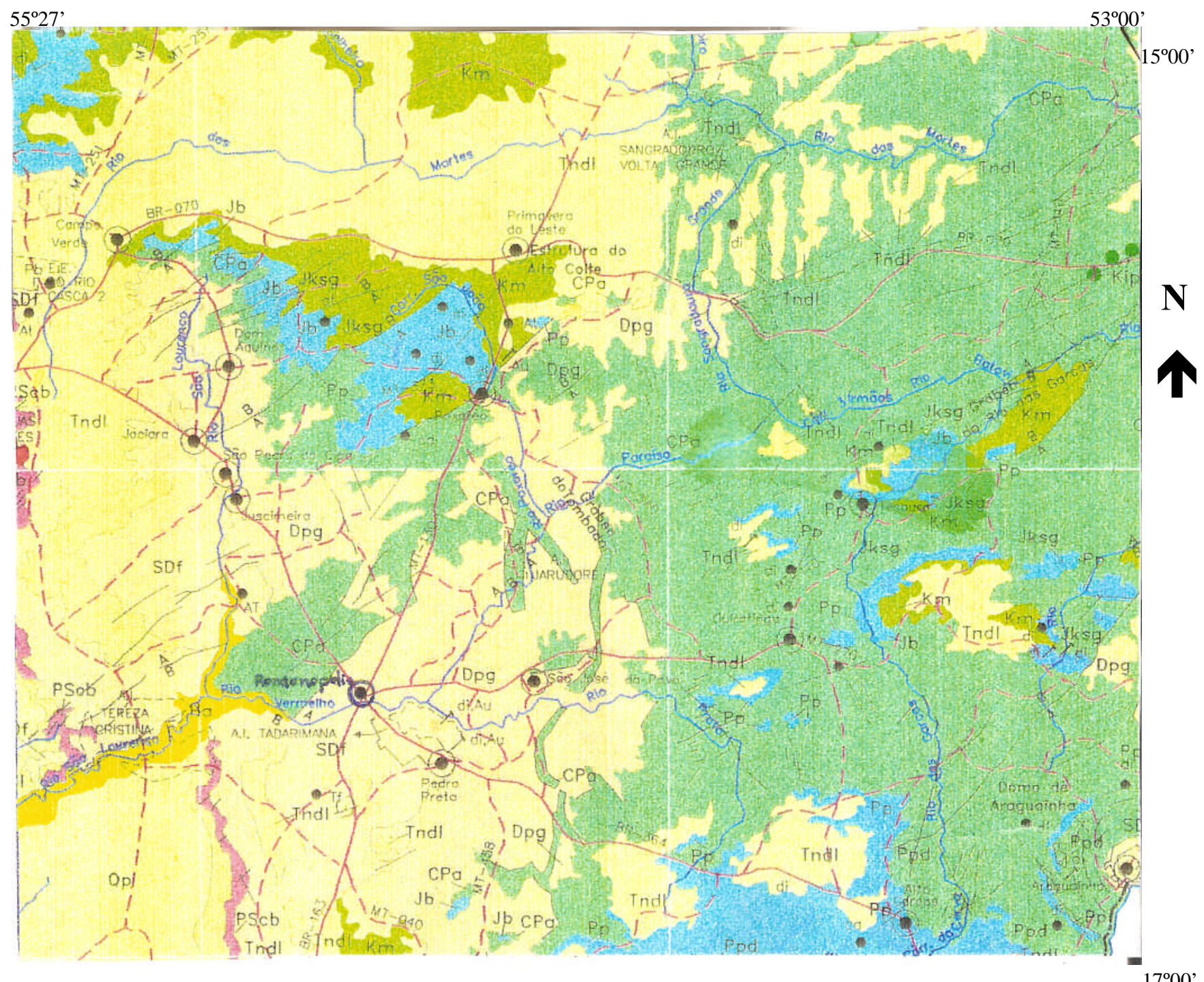

\begin{tabular}{|l|l|l|l|}
\hline \multicolumn{4}{|c|}{ Legenda das siglas cronoestratigráficas } \\
\hline Período Geológico & Grupo & \multicolumn{2}{c|}{ Formação } \\
\hline \multirow{2}{*}{ Quaternário } & & $\mathrm{Qp}$ & Formação Pantanal 1:1.500.000 \\
\cline { 3 - 4 } & & $\mathrm{Ha}$ & $\begin{array}{l}\text { Coberturas detríticas e lateríticas } \\
\text { Pleistoscênicas }\end{array}$ \\
\cline { 3 - 4 } & & Qdl & Aluviões Fluviais \\
\hline \multirow{2}{*}{ Terciário } & Tndl & $\begin{array}{l}\text { Coberturas detrito-lateríticas } \\
\text { Neogênicas }\end{array}$ \\
\hline Cretáceo & & $\mathrm{Km}$ & Formação Marília \\
& & $\mathrm{Kt}$ & Formação Tapirapuã \\
\hline Jurássico & Grupo São Bento & $\mathrm{Jksj}$ & Formação Serra Geral \\
\cline { 3 - 4 } & & $\mathrm{Jb}$ & Formação Botucatu \\
\hline Permiano & Grupo Guatá & $\mathrm{Pp}$ & Formação Palermo \\
\cline { 3 - 4 } & Grupo Itararé & $\mathrm{Cpa}$ & Formação Aquidauana \\
\hline Devoniano & Grupo Paraná & $\mathrm{Dpg}$ & Formação Ponta Grossa \\
\hline Siluriano & & SDf & Formação Furnas \\
\hline
\end{tabular}

Figura 19. Demonstração das formações geológicas que ocorrem nas áreas adjacentes à Cidade de Pedra (SEPLAN/MT, 1999) 
O desenvolvimento desses falhamentos e diaclasamentos em duas direções perpendiculares, em forma de "X", ocasionou um processo erosivo preferencial nessas direções, resultando em uma seqüência de morros em forma cônica.

$\mathrm{O}$ arenito é a rocha que configura a área em que se encontram os sítios arqueológicos, pertencem as Formações Geológicas da borda da Bacia do Paraná: Vila Maria, Furnas e Ponta Grossa.

A utilização dos arenitos é abrangente e não se liga somente àquelas rochas com características físicas mais propícias ao lascamento. Nas rochas utilizadas nas estruturas de fogueira, por exemplo, há uma preferência por arenitos enriquecidos em ferro, que ocorrem em pontos distribuídos por toda a área, está relacionado a processos diagenéticos de cimentação do arenito por óxidos de ferro, conferindo a rocha forma de plaquetas bastante endurecidas. Esse material é levado ao sítio arqueológico em tamanhos pequenos (possível de segurar com uma das mãos) variados e arranjados em montes, que por sua vez, estão associados principalmente a carvão, evidenciando estruturas de fogueira. É um material recorrente nas proximidades dos sítios Ferraz Egreja, Antiqueira e Vermelhos, onde são amplamente utilizados.

\subsubsection{Os afloramentos de origem primária}

Os arenitos com grau 2 de silicificação, assim como os quartzitos, ocorrem dentro da área da Cidade de Pedra, próximo a Ferraz Egreja e Vermelhos, estão associados a fraturamentos/diaclasamentos que ocorrem em escala de afloramento. Trata-se de arenitos da Formação Furnas que sofreram processos diagenéticos de cimentação em consequência do aquecimento gerado pela movimentação tectônica das rochas. Característico desse tipo de processo metamórfico, essas rochas tem um aspecto textural muito heterogêneo, com variações de silicificação, cor e granulometria, vistas mesmo em pequenas amostras, havendo contatos abruptos entre partes extremamente bem silicificadas e outras não, formando um verdadeiro mosaico de cores e texturas.

De uma maneira geral, os afloramentos dos arenitos silicificados e quartzitos são muito pontuais em consequência da configuração geológica regional, diferente do que ocorre em outras regiões do país, onde se formam amplas áreas de arenitos com boa silicificação, relacionados a outros processos geológicos, como o aquecimento gerado pelo contato com rochas ígneas. 


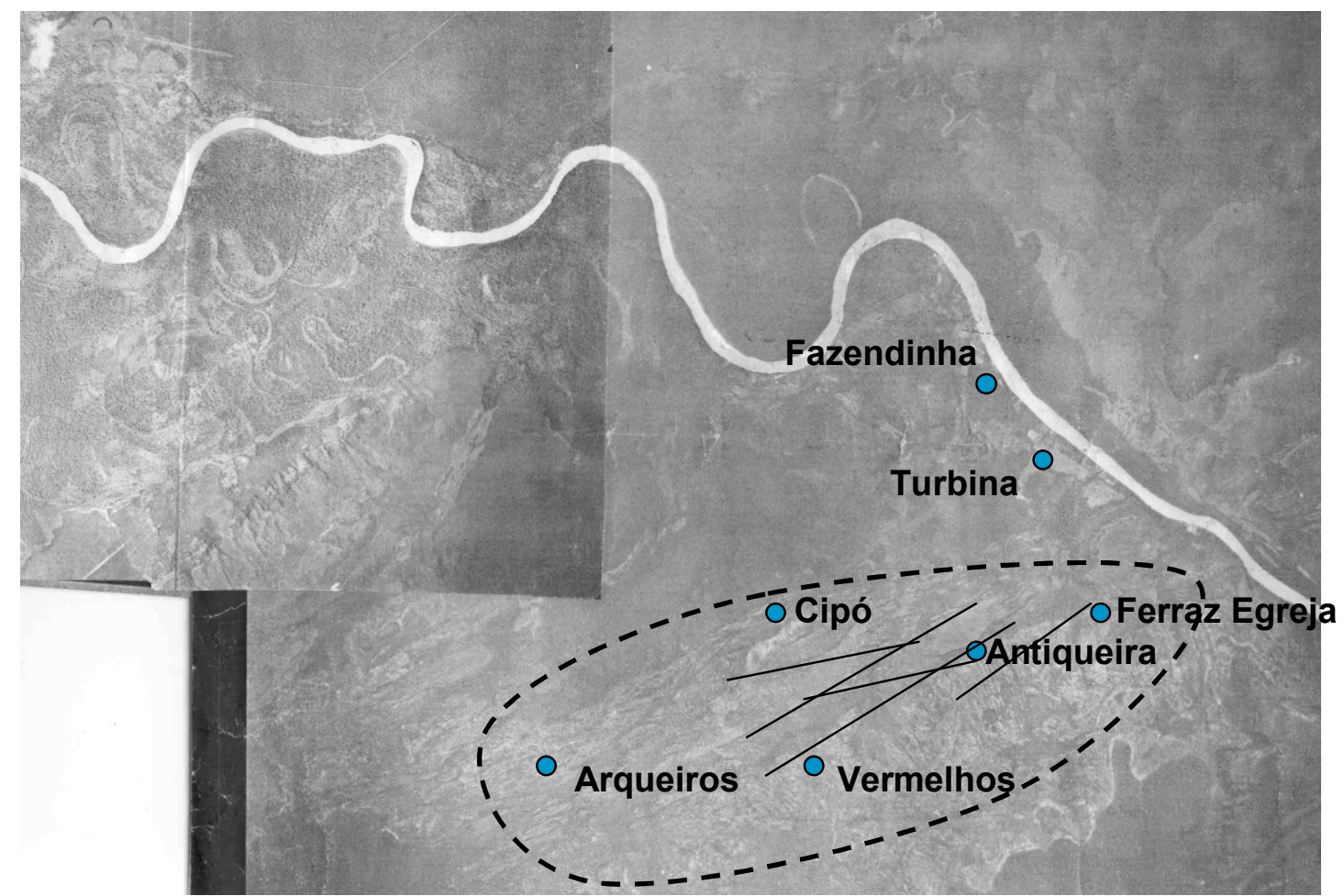

Figura 20. Representação da foto aérea da área em estudo (Exército do Brasil, 1966). Os pontos azuis representam as áreas onde se encontram os sítios arqueológicos e a linha tracejada à área de relevo mais acidentado, em contraste com a área mais aplainada do terraço do rio Vermelho (Figura representativa sem escala).

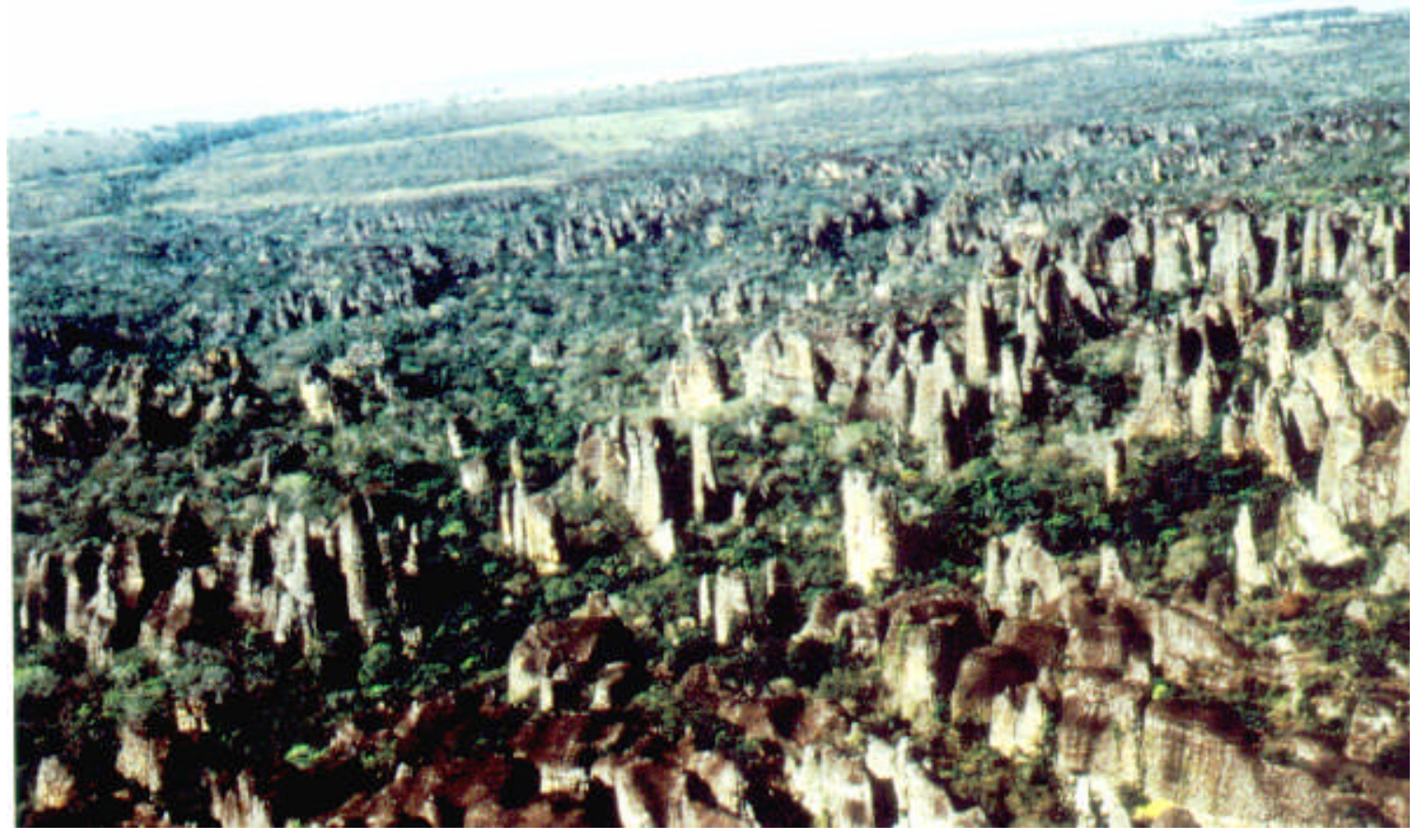

Figura 21. Vista da "Cidade de Pedra". 
Apesar de não serem fisicamente tão competentes para o lascamento, foram amplamente utilizados. Alguns desses afloramentos apresentam planos de fratura que propiciam uma fragmentação natural da rocha (figuras 34 e 35). Em dois desses afloramentos (Afl- 5 e 6, vide figura 66, 67) localizados respectivamente, por Thierry Aubry e Levy Figuti, foram identificados sinais de retirada do material bruto.

\subsubsection{Os afloramentos de origem secundária}

A análise do material lítico fornece indícios de que muito da matéria-prima ali lascada corresponde a seixos de arenito com excelente grau de cimentação e variação de cores em degrade e não abrupta, parecem estar associados a um material transportado por água, devido a sua textura superficial lustrosa. Os silexitos apesar de pertencerem a uma outra classe litológica, é citado junto aos arenitos, pois estes também, foram na maioria, coletados com forma arredondada e córtex característico de um transporte em água, esse é um fator interessante já que nem em terra, nem no rio Vermelho e nem nos córregos tributários essas concentrações de seixos foram localizados. O rio Vermelho, que é a drenagem principal, é atualmente bastante raso e arenoso, e não se formam no seu leito, cascalheiras atualmente visíveis, ao menos em $15 \mathrm{~km}$ para jusante e para montante do rio, estando este tipo de matéria-prima relacionada aos seus formadores, em regiões mais a montante onde ocorrem formações geológicas em que este tipo de litologia é característico, como é o caso da Formação Aquidauana.

No entanto, com o decorrer das prospecções ao longo do rio Vermelho, foram encontrados na base dos bancos de areia que se formam ao longo do rio, com espessuras de até 1,5 metros, pequenos seixos de arenito, sílex, silexito oolítico e arenitos em contato com sílex, idênticos aos materiais encontrados nos sítios. Esse dado estaria demonstrando que a dinâmica do rio pode ter sido bem diferente e que cascalheiras com seixos de dimensões maiores provavelmente estão sob os bancos de areia, visto que se tratava de um rio com maior energia hidráulica e leito mais estreito, segundo os próprios moradores da região.

Segundo Cunha (1998), os processos de erosão, transporte e deposição de sedimentos no leito fluvial alternam-se no decorrer do tempo sendo, especialmente, definidos pela distribuição da velocidade e da turbulência do fluxo dentro do canal. São 
processos dependentes entre si e resultam não apenas das mudanças no fluxo, como também da carga existente. O rio Vermelho, que a montante passa pelo município de Rondonópolis, vem ao longo dos anos sofrendo uma série de modificações que resultam, em parte, do aumento das atividades humanas realizadas fora da área dos canais, mas que modificam o comportamento da descarga e da carga sólida do rio. Tais atividades estendem-se para a bacia hidrográfica e estão ligadas ao uso da terra, como a remoção da vegetação, desmatamento, emprego de práticas agrícolas indevidas e urbanização.

A partir destes dados, é possível supor que a capacidade de transporte do rio Vermelho era maior, ainda mais considerando o controle estrutural exercido no rio antes de chegar a área da Cidade de Pedra. Dessa forma, é possível supor que seixos de arenito silicificado e silexitos, trazidos das formações a montante, associadas a outras drenagens tributárias do rio Vermelho, estariam em evidência, ao menos em períodos de seca, podendo indicar, por exemplo, uma coleta sazonal.

\subsection{Caracterização geológica e proveniência das rochas metamórficas}

As hipóteses levantadas com a análise petrográfica desse material foram confirmadas com os levantamentos de campo, tratava-se realmente de uma gradação proporcionada por metamorfismo dos arenitos.

O metamorfismo diz respeito aos processos de transformação em resposta a novas condições, uma rocha originalmente formada em um ambiente ígneo ou sedimentar recristaliza para produzir uma rocha metamórfica. A maioria das rochas metamórficas retém algumas características do material original tais como a composição química global ou feições maiores enquanto são desenvolvidas novas texturas e, freqüentemente, novos minerais.

Uma grande variedade de processos geológicos pode causar metamorfismo, incluindo-se aí o soterramento progressivo e conseqüente aquecimento de espessas seqüências sedimentares até atividades ígneas, bem como raros impactos de grandes meteoritos sobre a superfície da Terra. No caso da região de Rondonópolis há uma situação de metamorfismo que não é descrita na geologia regional da área. Esse 
metamorfismo produziu uma rocha de cor verde escura a preta, que a primeira vista engana se passando por uma rocha ígnea básica, que não existe na área.

A extensão dos trabalhos de campo permitiu chegar aos afloramentos desta rocha, que ocorrem de forma gradativa, do planalto a planície. Em uma área mais afastada da Cidade de Pedra (cerca de $19 \mathrm{~km}$ ), em afloramento de estrada, são encontradas rochas esverdeadas bastante foliadas e com planos de fraturas bem marcados e estruturas pronunciadas, aí estariam as rochas cuja litologia foi identificada, em análise microscópica, como quartzo-grauvaca, que estaria por sua vez, relacionada ao processo metamórfico já menos intenso (Afl-3, figura 63).

Em direção a planície, chega-se à área indígena Thereza Cristina onde habita o grupo Bororo Piegaba, o afloramento dessa rocha é encontrado no córrego que passa por essa área indígena, então denominado Piegabre, a cerca de $19 \mathrm{~km}$ da área da Cidade de Pedra já em outro contexto ambiental. O afloramento não é encontrado em cota positiva e só pode ser visto devido à escavação feita pela água. Há grandes blocos com planos de fratura bem marcados e assim como nos sítios arqueológicos, a cor superficial é verde, sendo estes, ainda coesos. É possível verificar também a variedade na granulometria destas rochas, que podem ser extremamente finas, numa fração silte, ou mais grossas, fração areia média a grossa.

Esse afloramento está localizado pontualmente e acredito não haver outra exposição dessa rocha mais próxima aos sítios. O acesso foi feito por terra, mas pode ser feito através dos rios: seguindo a jusante do rio Vermelho, este se torna afluente do rio São Lourenço, o córrego Piegabre é um dos tributários desse rio, já numa área de planície e em outro contexto ambiental.

Há indícios de que essa litologia esteja relacionada a um Metamorfismo Regional/ Dinamotermal: que geralmente é acompanhado por deformação, sob a forma de dobras e falhas de caráter diverso, exibindo amiúde, uma estrutura planar bem pronunciada, caracterizada pelo paralelismo de minerais placóides, especialmente micas, incluindo também feldspato e quartzo.

O Afloramento da aldeia Piegaba estaria relacionado a fase mais intensa desse metamorfismo gerando uma litologia mais coesa, a forma como se encontra estruturado permitiria um aproveitamento dos planos de fratura nas técnicas de polimento, e também lascamento, geralmente associados a confecção de lâminas de machado. 


\subsection{Os conjuntos litológicos}

Durante a análise petrográfica do material lítico, o material foi agrupado em conjuntos litológicos de acordo com características como silicificação, granulometria, variação de cores, córtex que geraram a seguinte classificação: 
Tabela 1. Representação do esquema utilizado na formação dos conjuntos litológicos em laboratório.

\begin{tabular}{|c|c|c|c|}
\hline \multicolumn{4}{|c|}{ ARENITOS } \\
\hline Cor & Silicificação & Granulometria & Conjunto \\
\hline $\begin{array}{l}\text { Matriz brancas com manchas } \\
\text { roxas }\end{array}$ & Ar-2 & (B) & Conjunto-A \\
\hline $\begin{array}{l}\text { Matriz rosa com manchas } \\
\text { roxas }\end{array}$ & Ar-2 & (B) & Conjunto-B \\
\hline Rosa & Ar-2 & (B) & Conjunto- $\mathrm{C}$ \\
\hline Laranjada & Ar-2 & (B) & Conjunto-D \\
\hline Vermelha & Ar-2 & (B) & Conjunto-E \\
\hline $\begin{array}{l}\text { Variedades vermelhas a roxas, } \\
\text { bege e rosa }\end{array}$ & Ar-3 & $(\mathrm{A} / \mathrm{B})$ & Conjunto-F \\
\hline Variedades de branco a rosa & Ar-3/Ar-4 & 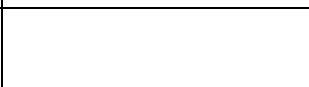 & Conjunto-G \\
\hline Bege & Ar-3 & A & Conjunto-H \\
\hline \multicolumn{4}{|c|}{ CORANTES } \\
\hline \multicolumn{3}{|l|}{ Seixos } & Conjunto-I \\
\hline \multicolumn{3}{|l|}{ Plaquetas e concreções } & Conjunto-J \\
\hline \multicolumn{4}{|c|}{ SILEXITOS } \\
\hline Cor & \multicolumn{2}{|r|}{ Tipo } & Conjunto \\
\hline Bege & \multicolumn{2}{|l|}{ Silexito Nodular } & Conjunto-L \\
\hline Cinza a vermelha & \multicolumn{2}{|c|}{ Silexito Brechóide } & Conjunto-M \\
\hline $\begin{array}{l}\text { Cinza, laranjada, rosa e } \\
\text { vermelha }\end{array}$ & \multicolumn{2}{|l|}{ Silexito Maciço } & Conjunto-N \\
\hline \multicolumn{4}{|c|}{ "ROCHAS METAMÓRFICAS" } \\
\hline Cor & \multicolumn{2}{|r|}{ Tipo } & Conjunto \\
\hline Verde a amarela & \multicolumn{2}{|l|}{ Compacta } & Conjunto-O \\
\hline Verde & \multicolumn{2}{|l|}{ Foliada } & Conjunto-P \\
\hline Verde escura a Preta & \multicolumn{2}{|l|}{ Compacta } & Conjunto-Q \\
\hline
\end{tabular}


Posteriormente, com o andamento das prospecções foi possível abordar outros aspectos e propor uma formulação de conjuntos litológicos mais abrangente que seria mais consistente e coerente na relação material lítico arqueológico/ fonte de matériaprima.

Assim sendo, a tabela abaixo é apresentada:

Tabela 2. Representação da formação dos conjuntos litológicos, com base nas fontes de matérias-primas.

\begin{tabular}{|c|c|c|}
\hline Matéria-Prima & Caracterização & Conjunto \\
\hline \multirow{4}{*}{ Arenitos } & $\begin{array}{l}\text { Arenito de cor rosa, grau de silicificação } \mathrm{Ar}-2 \text {, } \\
\text { proveniente de afloramento, granulometria média }\end{array}$ & A \\
\hline & $\begin{array}{l}\text { Arenito de cores diversas, vermelha, laranjada, bege, } \\
\text { com grau de silicificação Ar-2, proveniente de } \\
\text { afloramento, granulometria média a grossa }\end{array}$ & B \\
\hline & $\begin{array}{l}\text { Arenito "mosaico", grau de silicificação } \mathrm{Ar}-3 \text {, } \\
\text { proveniente de afloramento }\end{array}$ & $\mathrm{C}$ \\
\hline & $\begin{array}{l}\text { Arenitos provenientes de seixos coletados no rio } \\
\text { Vermelho, exibem granulometria fina e excelente } \\
\text { silicificação (Ar-3) }\end{array}$ & $\mathrm{D}$ \\
\hline \multirow{2}{*}{ Silexitos } & Silexitos maciços, oolíticos e nodulares & $E$ \\
\hline & Silexitos brechóides & \\
\hline \multirow{3}{*}{$\begin{array}{c}\text { Rochas } \\
\text { Metamórficas }\end{array}$} & $\begin{array}{l}\text { Quartzitos, geralmente associados a heterogeneidade } \\
\text { dos afloramentos do conjunto C }\end{array}$ & $\mathrm{C} 2$ \\
\hline & "Rochas Verdes" compactas & G \\
\hline & Quartzo-grauvacas & G1 \\
\hline \multirow{2}{*}{ Minerais } & Hematitas & $\mathrm{H}$ \\
\hline & Quartzos & $\mathrm{I}$ \\
\hline
\end{tabular}




\subsection{Os conjuntos litológicos e seus afloramentos}

\subsubsection{Arenitos}

\section{$\Rightarrow$ Conjuntos litológicos A, B e C}

Os arenitos do conjunto $\mathrm{B}$ e $\mathrm{C}$ foram distinguidos para uma análise laboratorial, porém, com o avanço das prospecções em campo, observou-se que tais rochas podiam ser encontradas associadas, em afloramentos que apresentam variedades de cores e graus de silicificação (afloramentos 1, 2, 4, 5 e 6, vide figura 66, 67).

Os arenitos do conjunto A, são recorrentes na geologia da região, principalmente nas área adjacentes a Cidade de Pedra, onde são inclusive explorados economicamente, como brita.

Tanto o conjunto A quanto os conjuntos B e C ocorrem nos sítios Ferraz Egreja e Vermelhos, associados a produtos de lascamento (fragmentos e lascas) que, por vezes, podem apresentar trabalho secundário, lascas retocadas e fragmentos com reentrâncias.

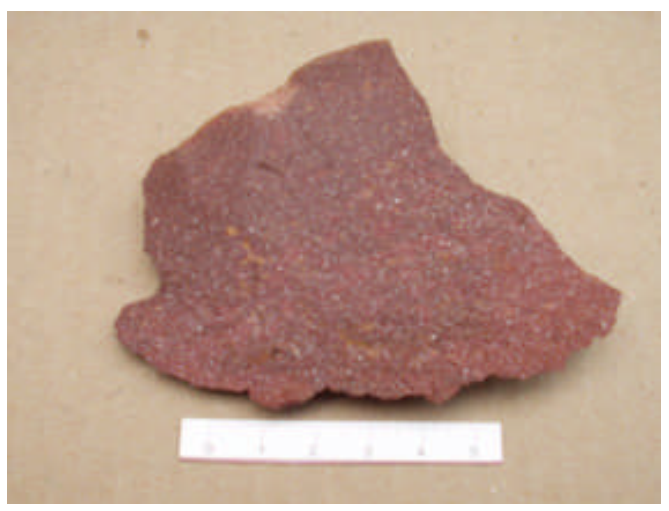

22. Arenito do conjunto B

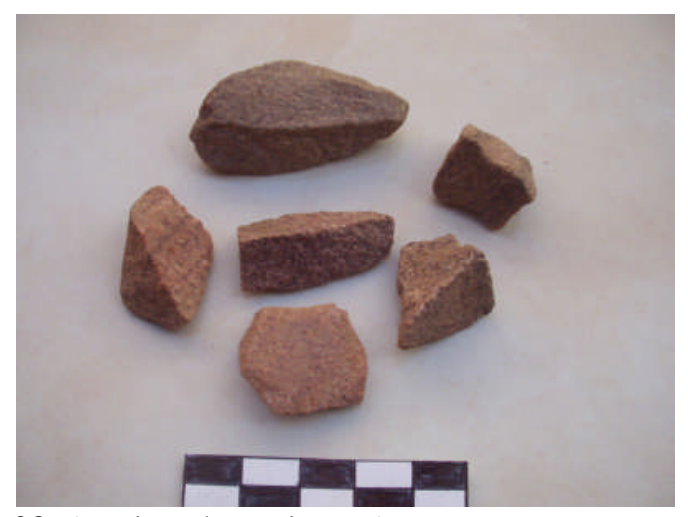

23. Arenitos do conjunto A 


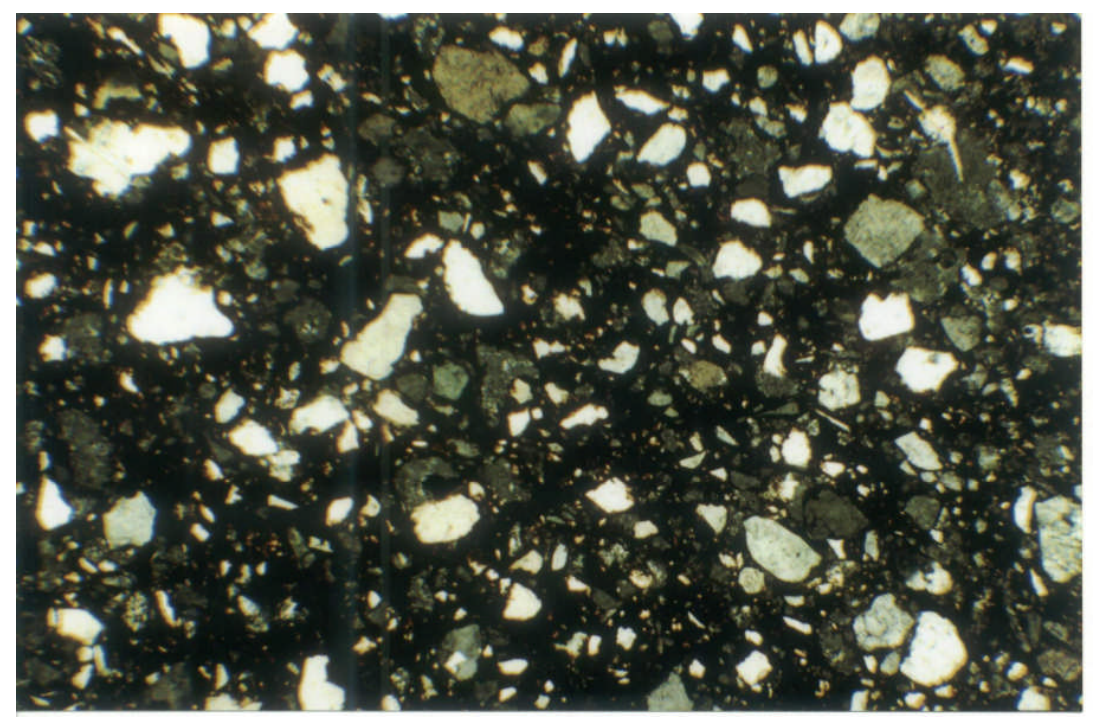

Figura 24. Arenito AR-2 (Conjunto A/B): Fotografia de lâmina petrográfica, objetiva 2,5. Pode-se observar a angulosidade dos grãos de quartzo e sua granulometria fina a média, não havendo uma boa seleção dos grãos. O cimento silicoso está presente mas não preenche com plenitude os poros da rocha.

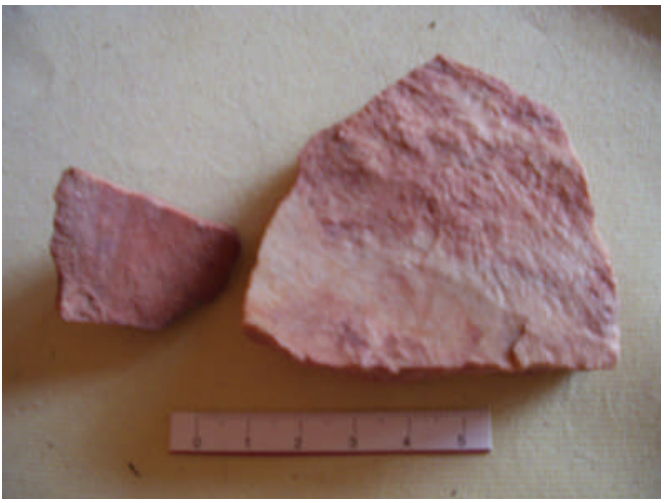

25. Amostra do conjunto $\mathrm{C} / \mathrm{C} 2$, nota-se a diferença textural (afl. 1)

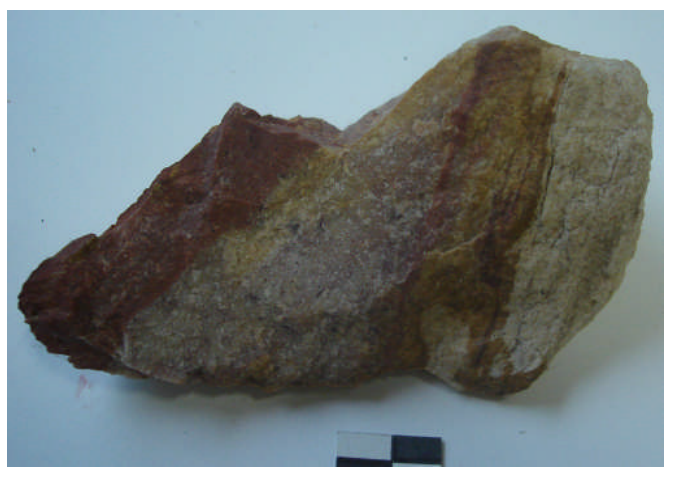

27. Arenito do conjunto C (Afl. 2), nota-se a variação de cores e texturas, contato com o arenito friável da formação Furnas.

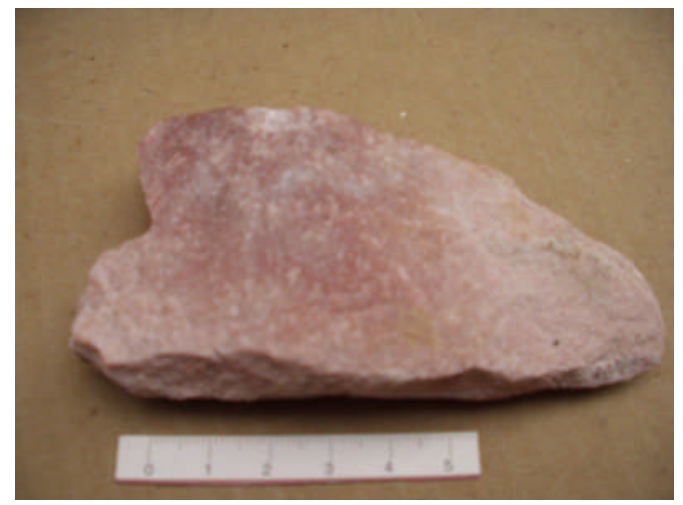

26. Arenito do conjunto $\mathrm{C}$.

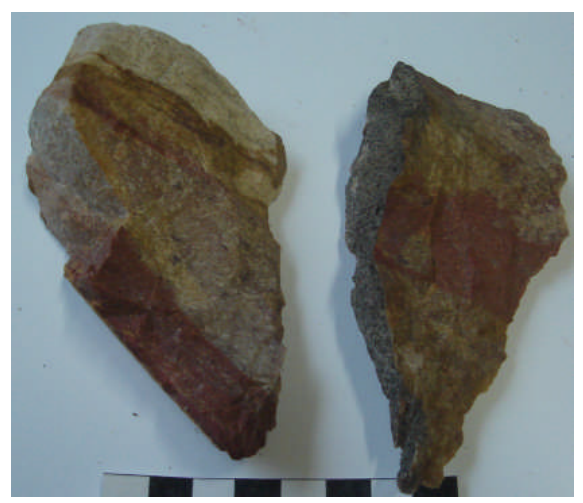

28. Arenito do conjunto C (Afl. 2) 


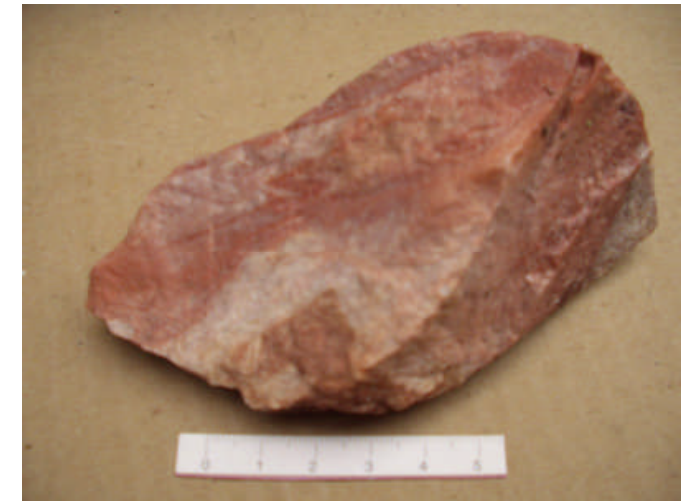

29. Amostra do conjunto $\mathrm{C} / \mathrm{C} 2$ localizados no afloramento 1

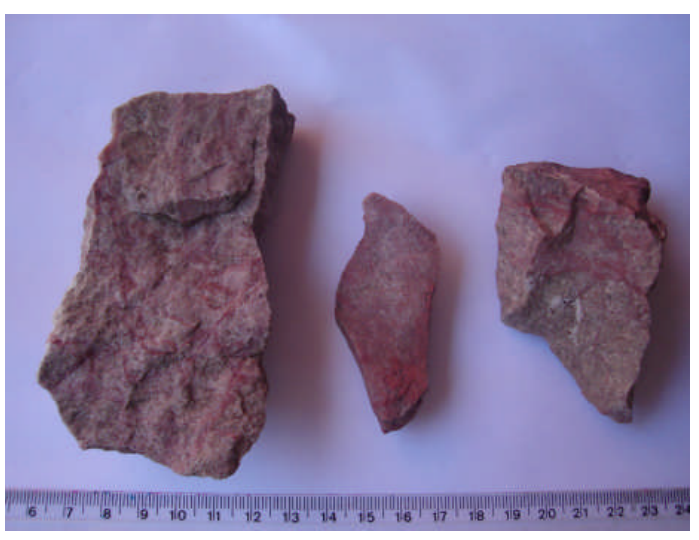

31. Arenitos/ quartzitos (conjuntos $\mathrm{C} / \mathrm{C} 2$ ) - Afl. 6

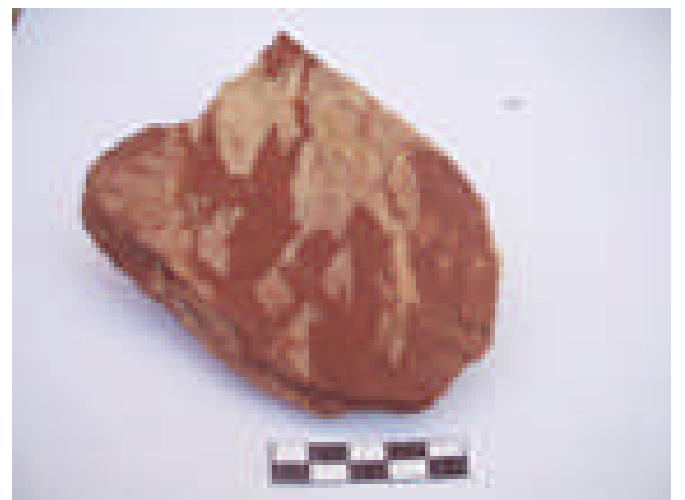

30. Arenito "mosaico", Conjunto $\mathrm{C} / \mathrm{C} 2$, afl. 1

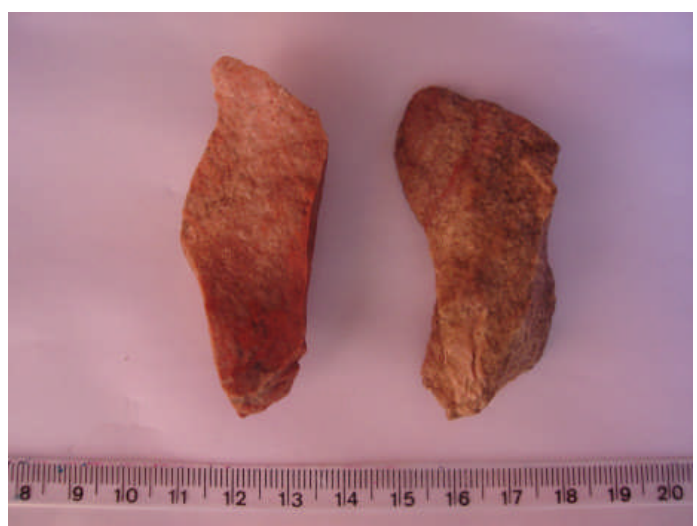

32. Material lascado associado ao Afl. 6 (vide fig. 66 e 67 )

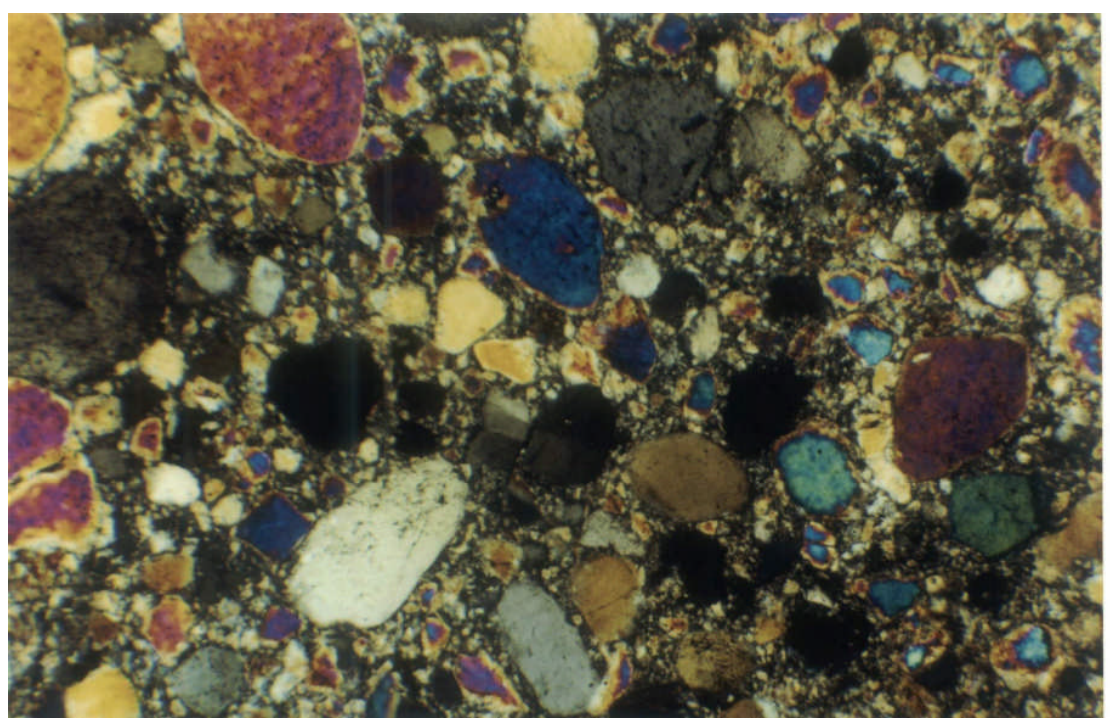

Figura 33. Quartzito (Conjunto C/C2): Fotografia de lâmina petrográfica, objetiva 2,5. Observa-se grãos de quartzo com bom arredondamento e uma má seleção dos grãos. Nota-se uma recristalização e não uma cimentação por sílica. 


\section{Conjuntos C/C2: Afloramento 1 (vide figuras 66 e 67)}

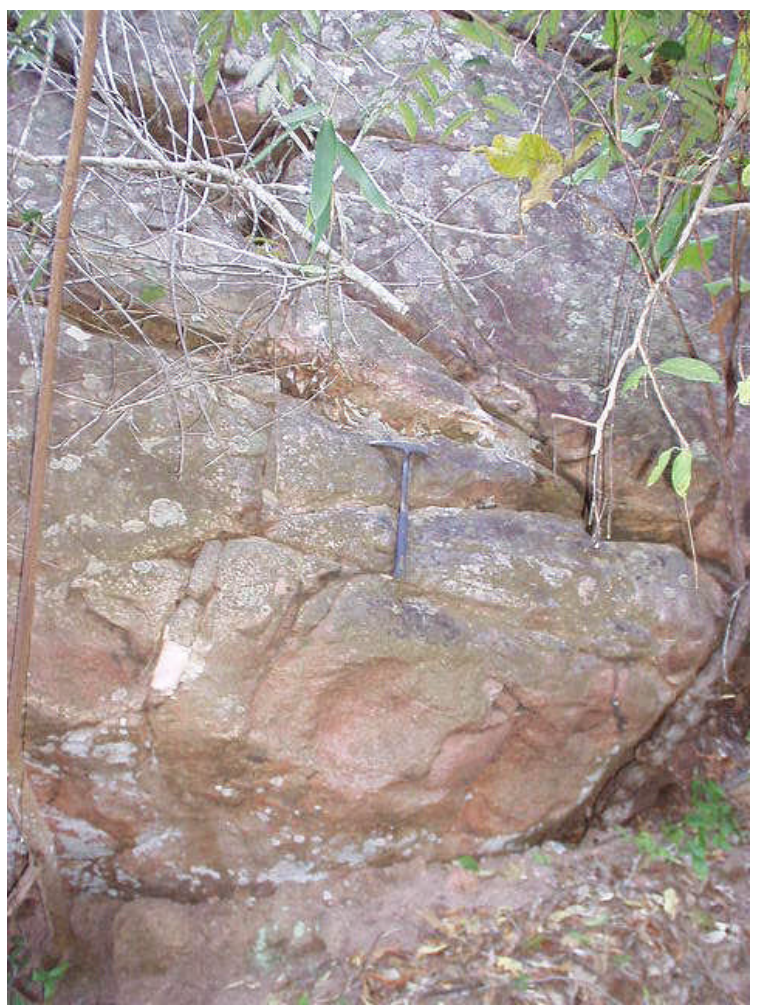

34.

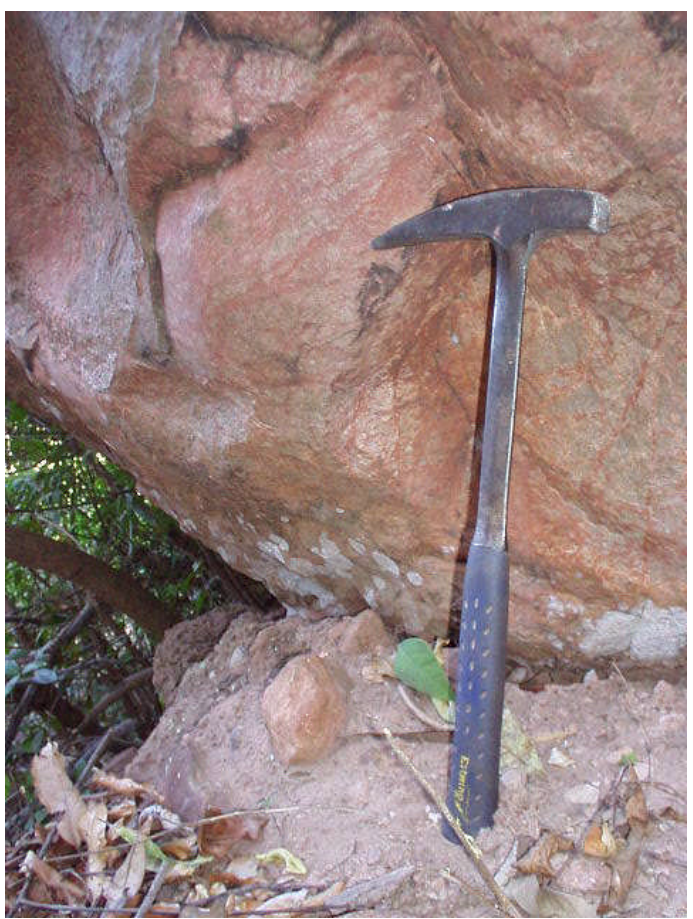

36.

Figuras: (34 e 35) - Afloramento de arenito do Conjunto $\mathrm{C} / \mathrm{C} 2$, ocorre isoladamente em meio à arenitos mais friáveis da Formação Furnas. (36) Detalhe do afloramento, bastante maciço. 


\section{$\Rightarrow$ Conjunto litológico D}

Os arenitos do conjunto $\mathrm{D}$, apresentam o melhor grau de silicificação, é constituído basicamente por grão de quartzo, com bom arredondamento, que contribuem para uma maior aptidão ao lascamento. Estão associados ao material transportado pelo rio Vermelho, apresentam córtex liso e lustroso, característico em blocos de rochas que são transportados em meio hidráulico por longas distâncias.

Ocorrem nos sítios Fazendinha, Ferraz Egreja, Vermelhos, Arqueiros e Caverna do Cipó, associados a produtos de lascamento, que em grande maioria, correspondem a estilhas, lascas e fragmentos de pequenas dimensões. Núcleos e utensílios, como raspadores, são encontrados, em pouca quantidade, nos sítios Ferraz Egreja e Vermelhos, nesses sítios, o lascamento pôde ser evidenciado in situ (Vilhena-Vialou, 2000). 


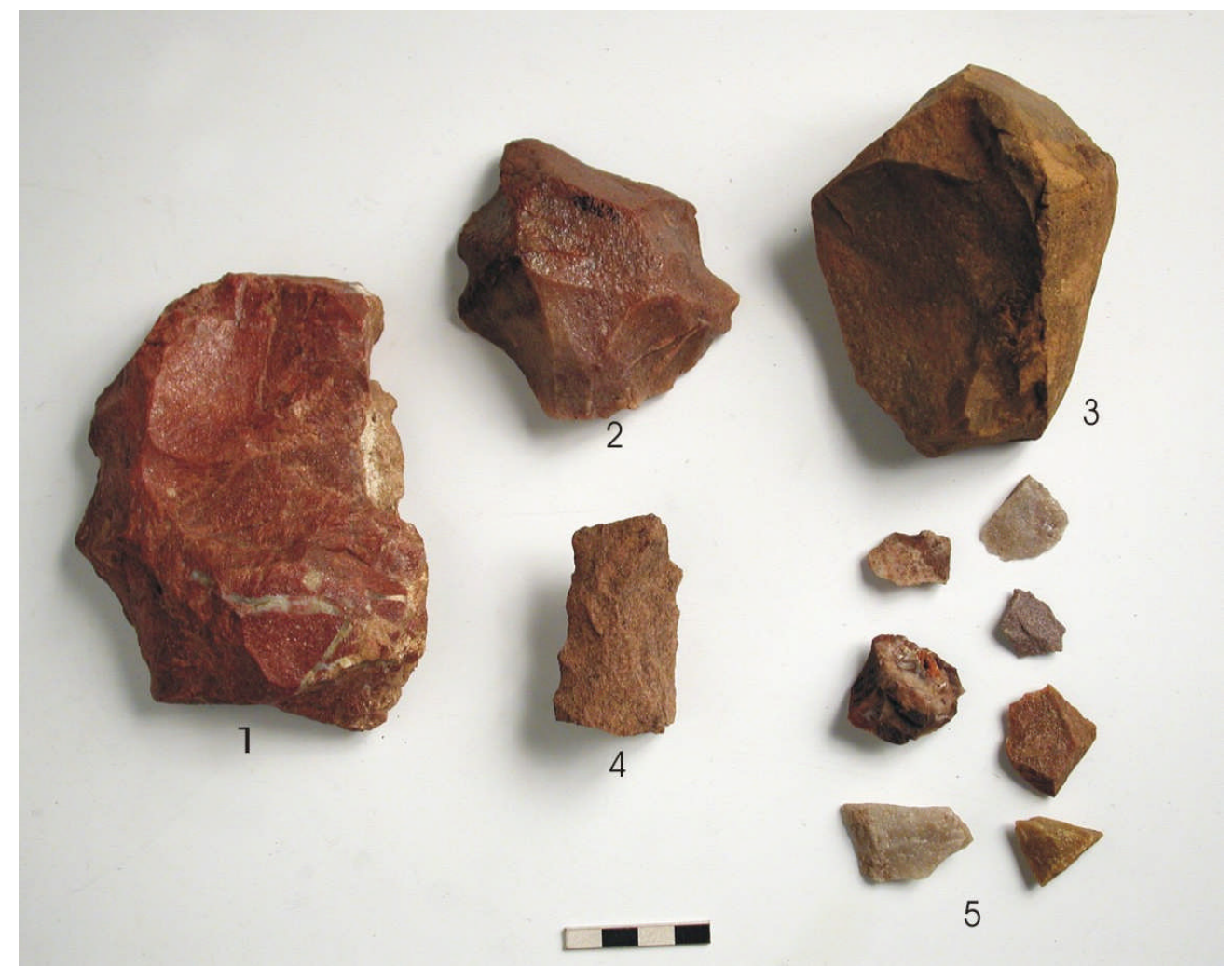

Figura 37. Exemplificação dos utensílios confeccionados em arenito com diferentes graus de silicificação: (1) Peça com reentrância em arenito (Ar-3 com veio de silexito - Conj. D), Sítio Fazendinha. (2) Peça com reentrância em arenito (Ar-3 - Conj. D), Sítio Abrigo Vermelhos. (3) Fragmentação de núcleo de arenito (Ar-2 - Conj. D), Sítio Fazendinha. (4) Peça com reentrância em arenito (Ar-2 - Conj. A), Sítio Ferraz Egreja. (5) Conjunto de lascas em arenito e arenito em contato com silexito (Ar-3 - Conj. D), Sítio Ferraz Egreja

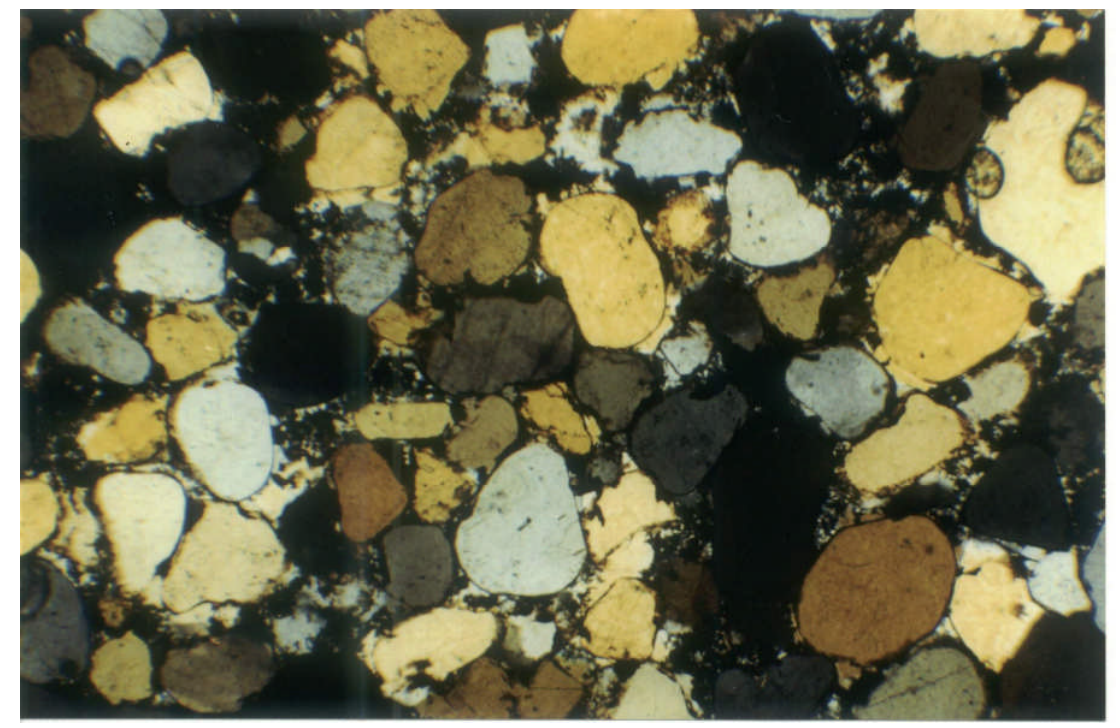

Figura 38 - Ar-3 (Conjunto D): Fotografia de lâmina petrográfica, objetiva 2,5. Os arenitos desse conjunto apresentam, em geral, grãos melhor selecionados, com bom arredondamento. Os espaços entre os grãos são muito inferiores as amostras anteriores e são em maioria preenchidos pelo cimento silicoso. 


\subsubsection{Silexitos}

Os silexitos foram subdivididos em: maciços, nodulares, ooliticos que compõe o conjunto $\mathrm{E}$ e brechóides, que compões o conjunto $\mathrm{F}$, todos eles produto de depósito secundário de aluvião feito pelo rio Vermelho, assim como os arenitos do conjunto D.

Toda variedade de silexitos do conjunto E é encontrada apenas no sítio Ferraz Egreja, no sítio Vermelhos ocorrem basicamente os silexitos brechóides. Nos sítios Cipó, Arqueiros, Fazendinha e Turbina são encontrados apenas silexitos maciços, associados a estilhas e lascas de pequenas dimensões e baixas quantidades.

Nos sítios Ferraz Egreja e Vermelhos, há presença de instrumentos nestes conjuntos, mas a maioria do material lítico é constituído por estilhas, lascas e fragmentos de pequenas dimensões.
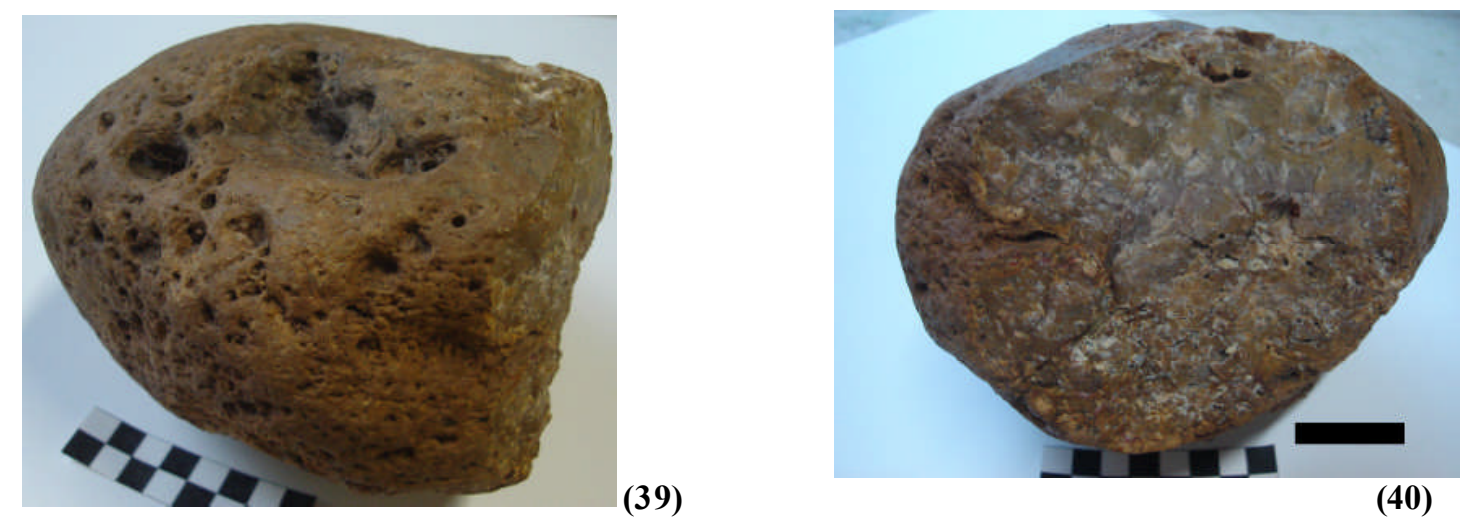

Figuras: (39-40) Bloco de silexito nodular, localizado nos sedimentos transportados pelo rio Vermelho, a montante da Cidade de Pedra.
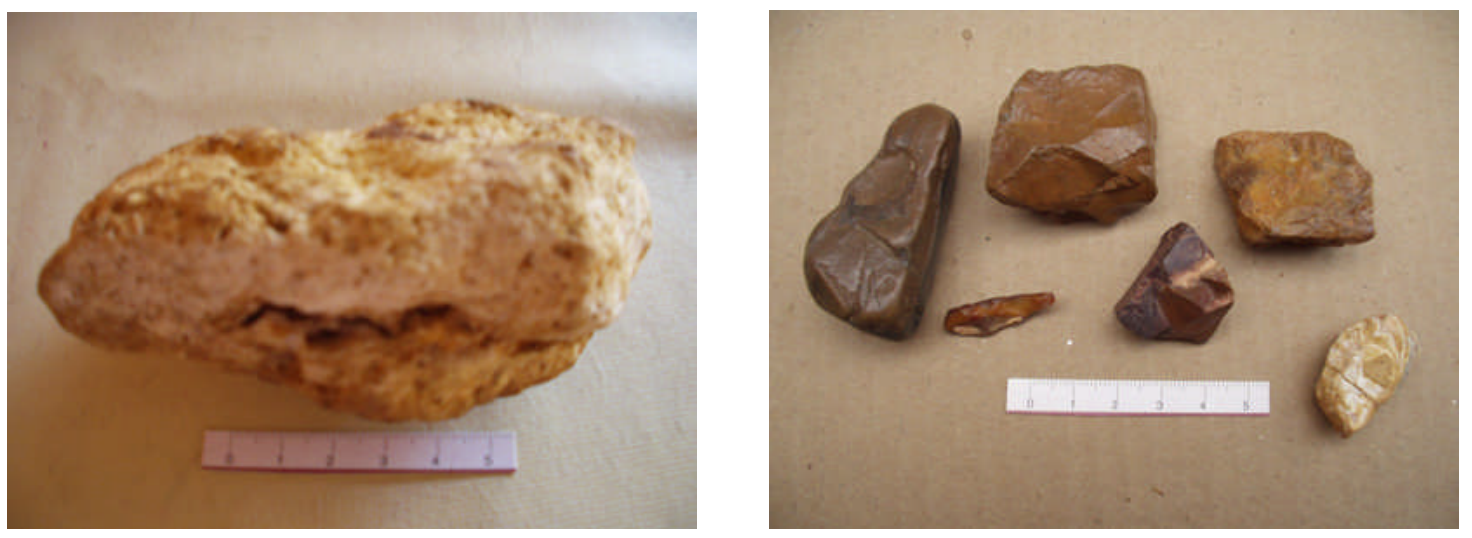

(41)

(42)

41. Amostra de seixo de arenito friável com geodos de silexito coletado no rio Vermelho, esse tipo de material é encontrado no sítio Ferraz Egreja. 42. Silexitos maciços, também provenientes do rio Vermelho 


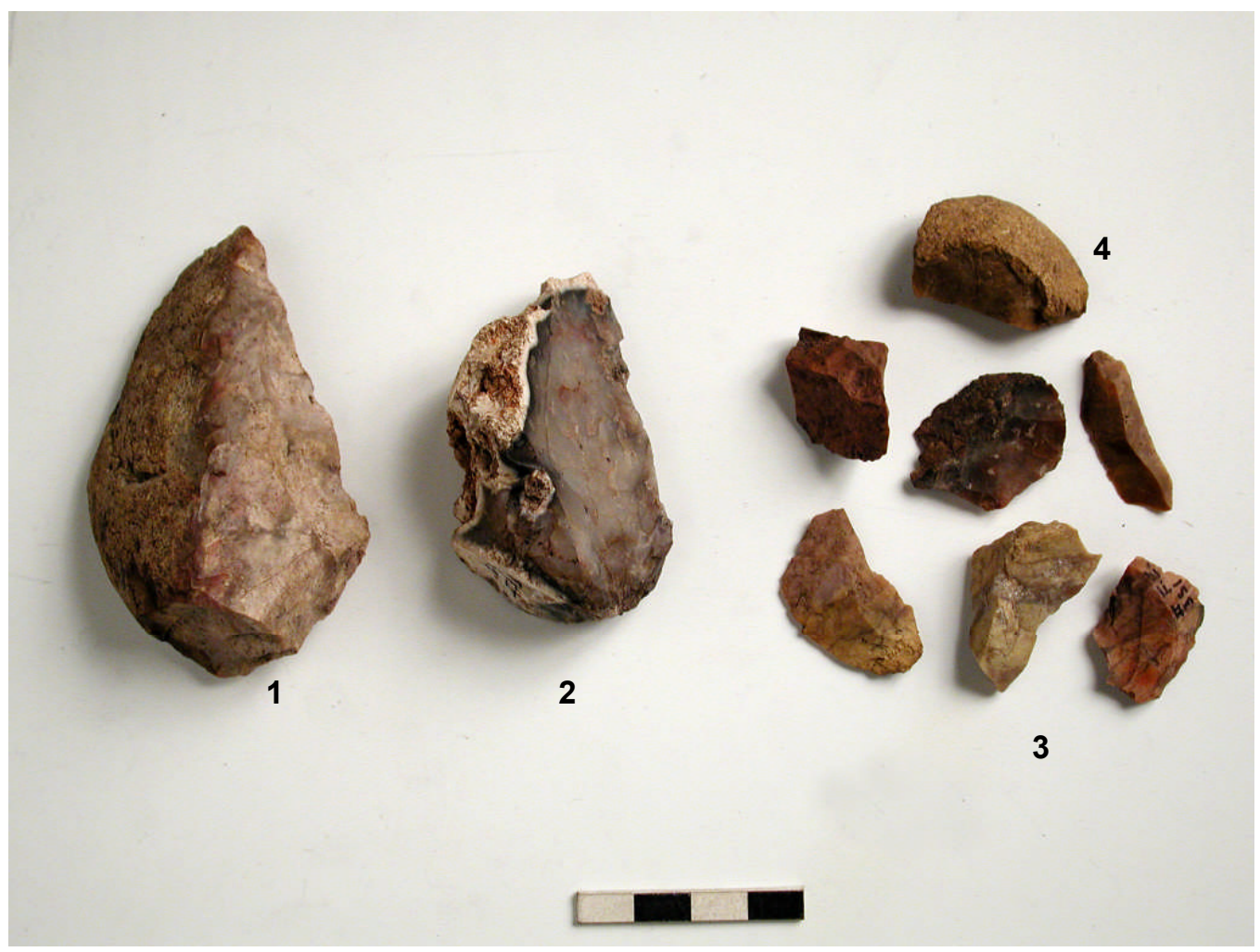

Figura 43. Conjunto de peças encontradas nos sítios Ferraz Egreja $(2,3,4)$ e Vermelhos (1) demonstrando a variedade dos fragmentos em silexito (Conj. E). O córtex presente em algumas das peças $(1,2,4)$ confere com o material proveniente do rio Vermelho.

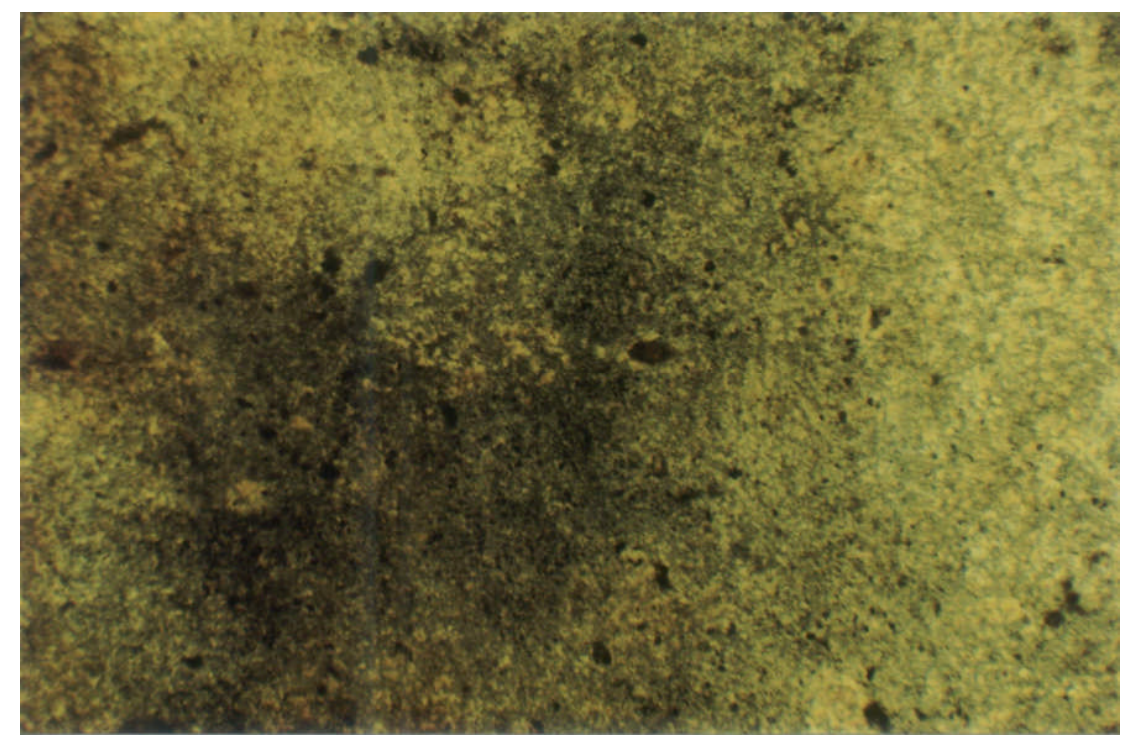

Figura 44 - Conjunto E: Fotografia de lâmina petrográfica de silexito maciço. Quartzo criptocristalino. 


\subsubsection{Rochas Metamórficas}

\section{$\Rightarrow$ Conjunto G1}

As rochas do conjunto $G$ foram extensamente utilizadas, no entanto, seu afloramento é o que mais se distancia dos sítios estudados. Esse conjunto se subdivide em dois (G e G1), em conseqüência de uma variação na estrutura da rocha que as torna diferentes mas relacionadas a um mesmo processo geológico de metamorfismo.

As rochas do afloramento 3 (vide figuras 66 e 67), correspondem a quartzograuvacas, sua estrutura foliada a torna extremamente quebradiça, no entanto, a indícios de trabalho de lascamento nesta rocha no sítio Ferraz Egreja, Vermelhos e Antiqueira.

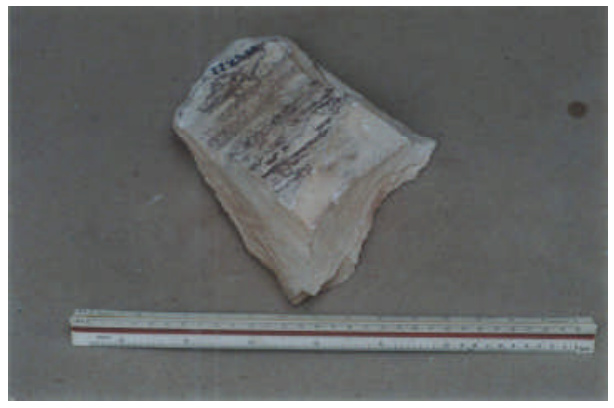

45. Amostras do conjunto G1 (Afl. 3)

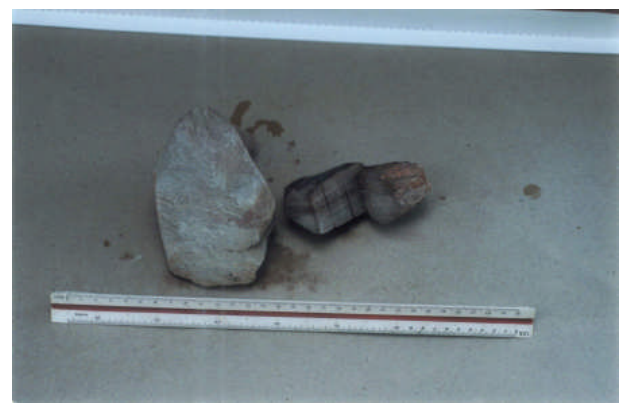

46. Amostras do conjunto G1 (Afl. 3)

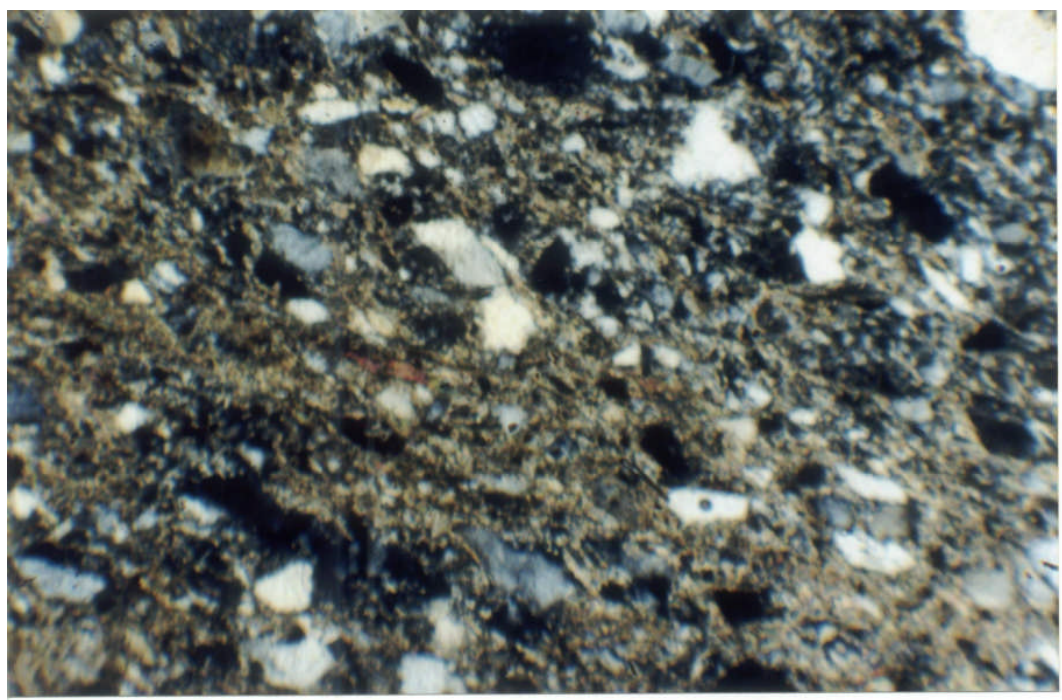

Figura 47. Conjunto G1: Fotografia de lâmina petrográfica, objetiva 2,5. Grãos de quartzo envoltos em uma matriz argilosa que supera $15 \%$ da amostra. Nota-se a orientação dos grãos. 
Conjunto G1: Afloramento3 e entorno (vide mapa das figuras 66 e 67)
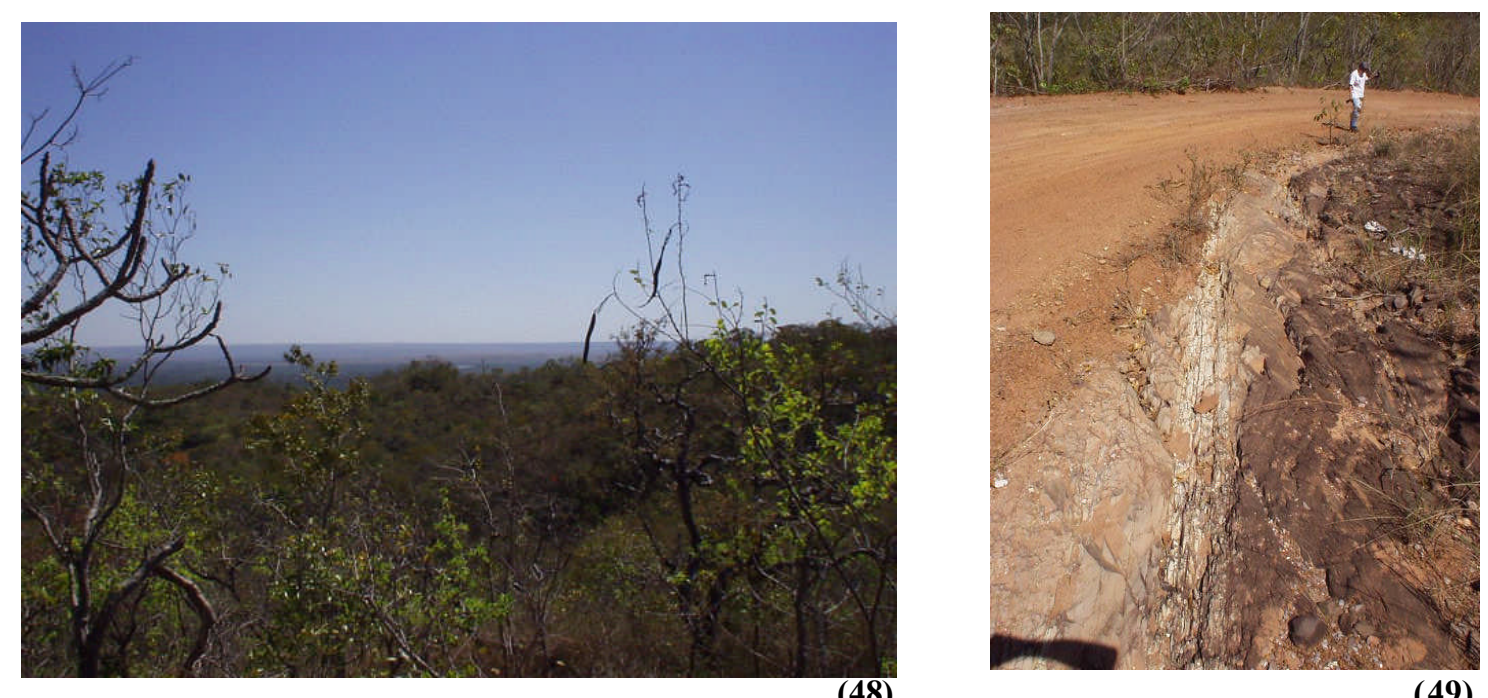

(48)

(49)
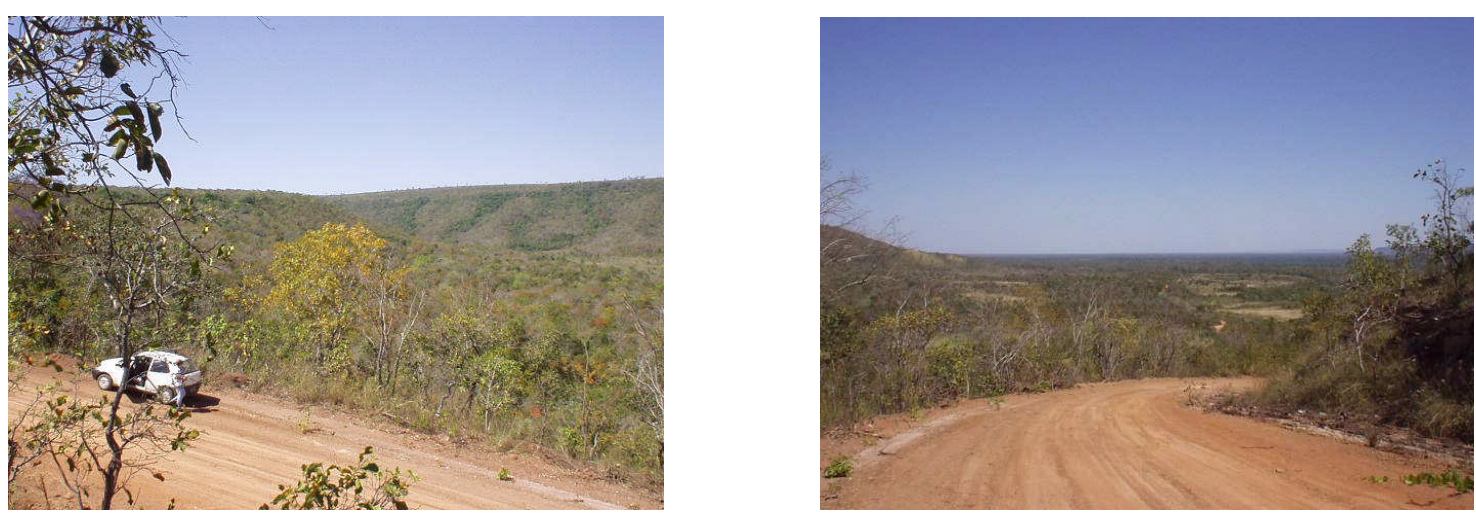

(50)

(51)

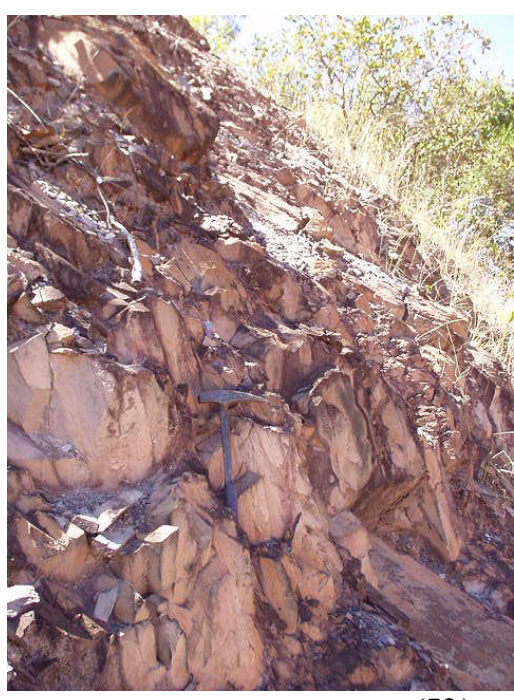

(52)

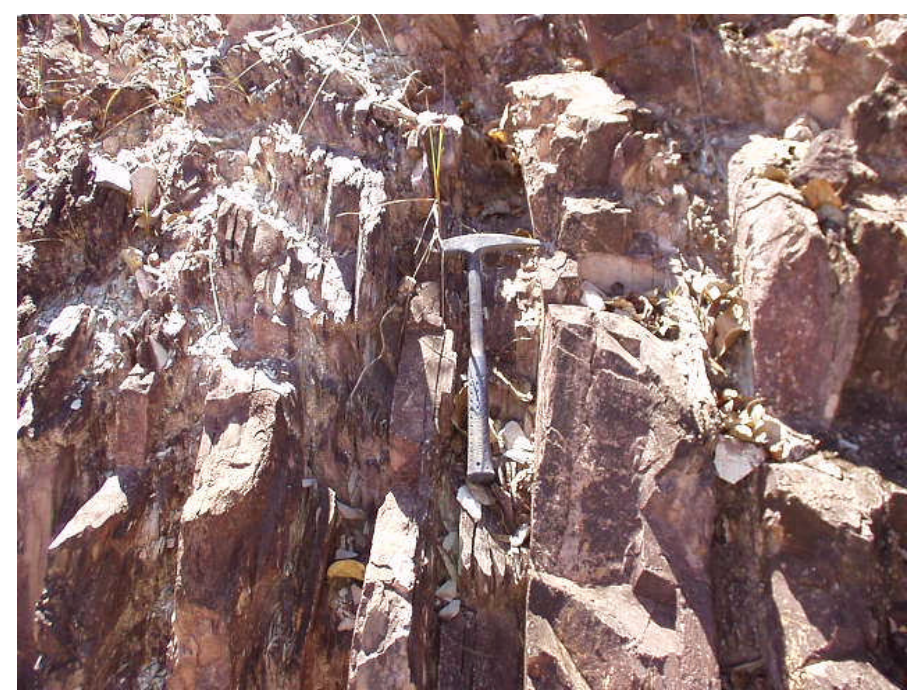

(53)

Figuras: (48) Vista da área de entorno, rio Vermelho ao fundo; (50 e 51) Vista da área de entorno, feições geomorfológicas em arenito da Formação Furnas; $(49, \mathbf{5 2}, \mathbf{5 3})$ Afloramento de quartzo-grauvaca marcado por intenso fraturamento 


\section{$\Rightarrow$ Conjunto G}

As rochas do conjunto $\mathrm{G}$, são encontradas em todos os sítios arqueológicos em estudo. Nos sítios Cipó e Antiqueira, são encontrados apenas os artefatos propriamente ditos, lâminas de machado que podem ser inteiramente polidos, como a que foi encontrada no sítio Cipó, ou com técnicas de lascamento e polimento associados, como no sítio Antiqueira.

Nos demais sítios, além dos utensílios polidos, são encontradas lascas e fragmentos, que são em grande parte naturais, devido às propriedades da rocha. As variações de cores não são considerados nesse conjunto, pois os tons mais esverdeados são conseqüência de alteração causada pela umidade do sedimento em alguns sítios.

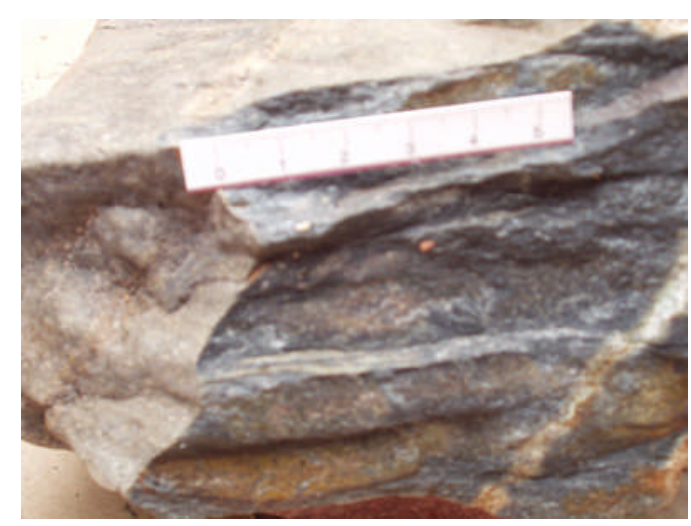

(55)

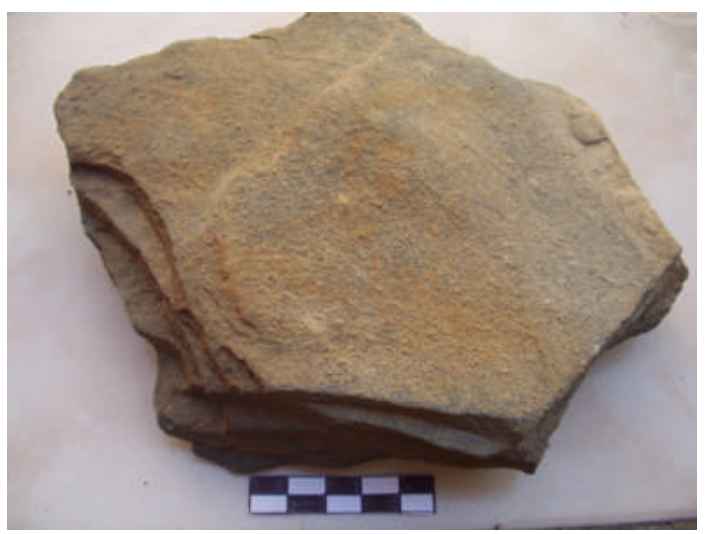

(54)
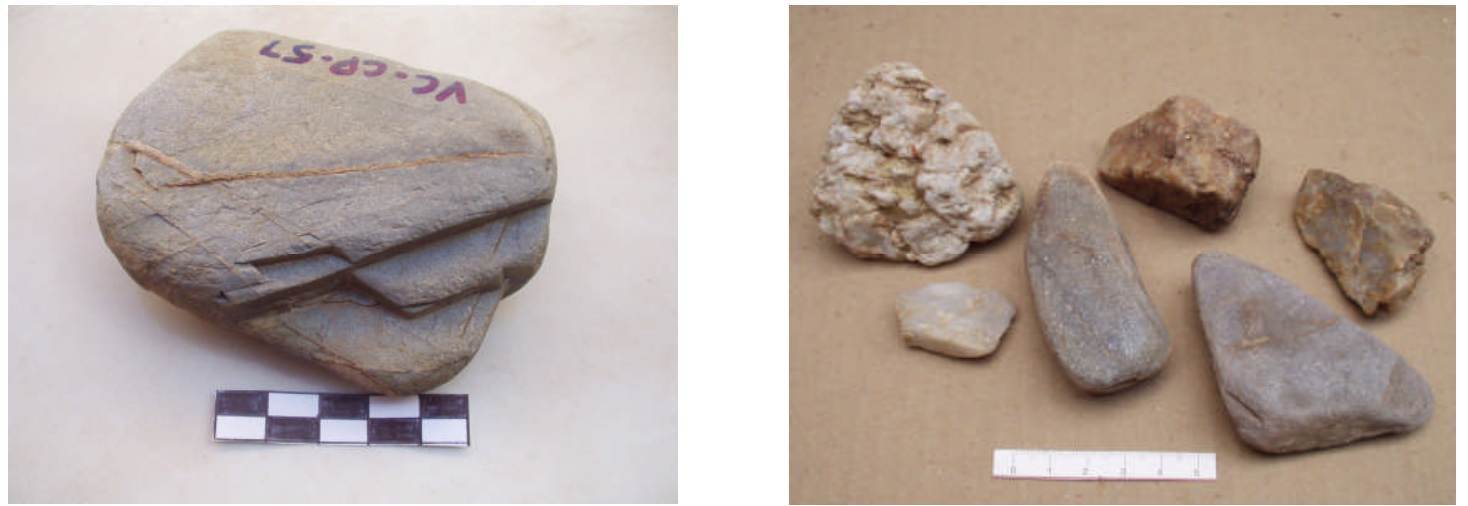

(56)

(57)

Figuras 54 a 56. Amostras do conjunto G coletadas no afloramento 4. (57) Amostras de quartzo encontrados associados a essas formações. 


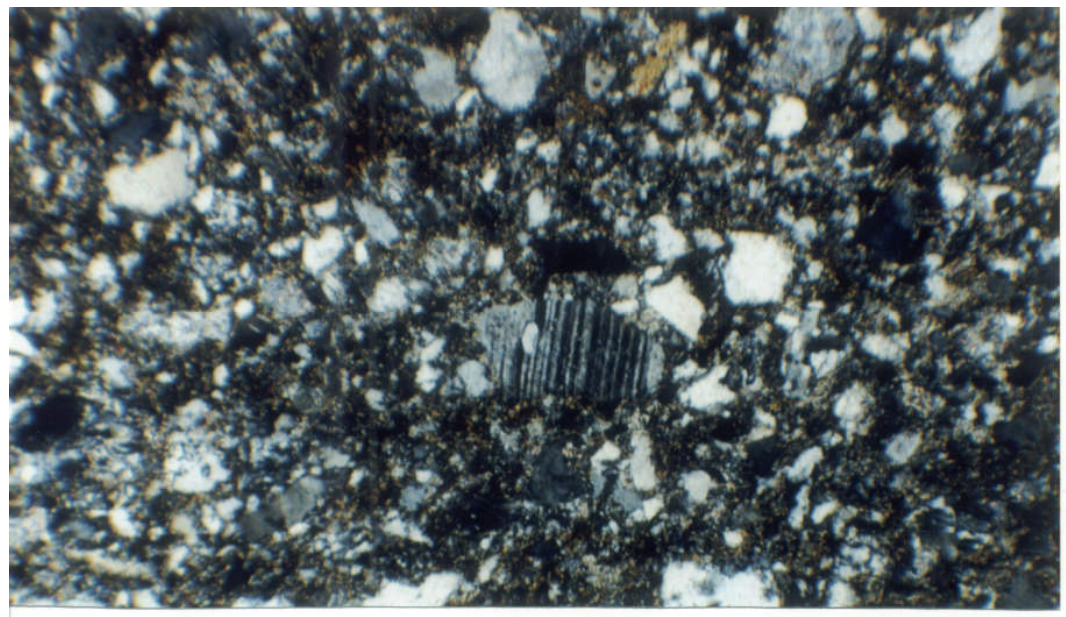

Figura 58. Conjunto G: Fotografia de lâmina petrográfica, diferencia-se do quartzo-grauvaca por apresentar uma maior diversidade mineralógica, composta por quartzo, feldspatos, zircão e epidoto e por sua estrutura mais compacta.

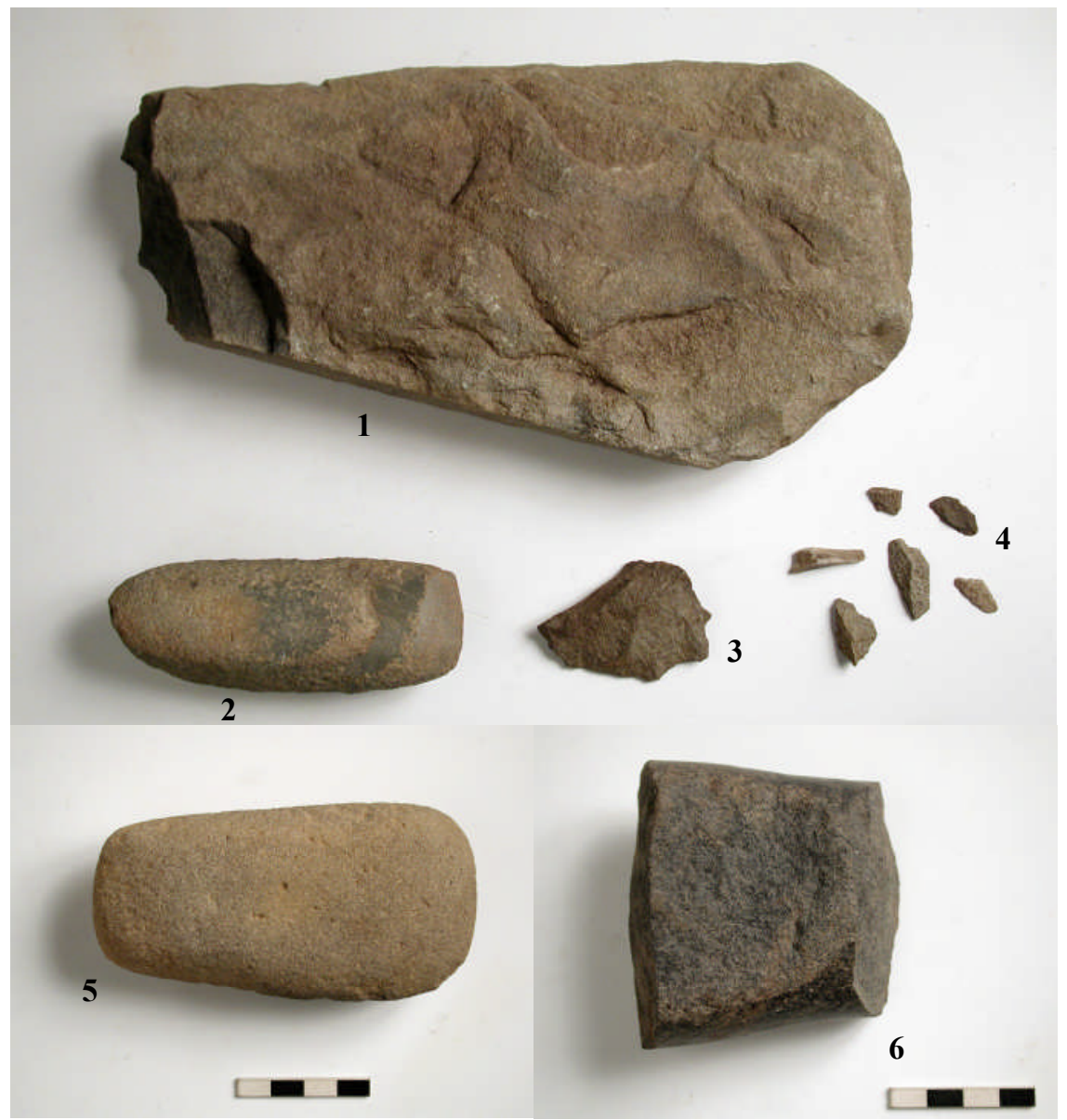

Figura 59 - Conjunto de peças líticas retiradas de diversos sítios da região. Essa rocha, é a única matériaprima que ocorre em todos os sítios e é trabalhada tanto através de lascamento como de polimento. Fazendinha (1, 2), Ferraz Egreja (3, 4), Cipó (5), Arqueiros (6). Apesar da variação na cor e algumas vezes na textura, os estudos de microscopia petrográfica mostraram se tratar do mesmo material. 
Conjunto G: Afloramento 4 (vide mapa das figuras 66 e 67)
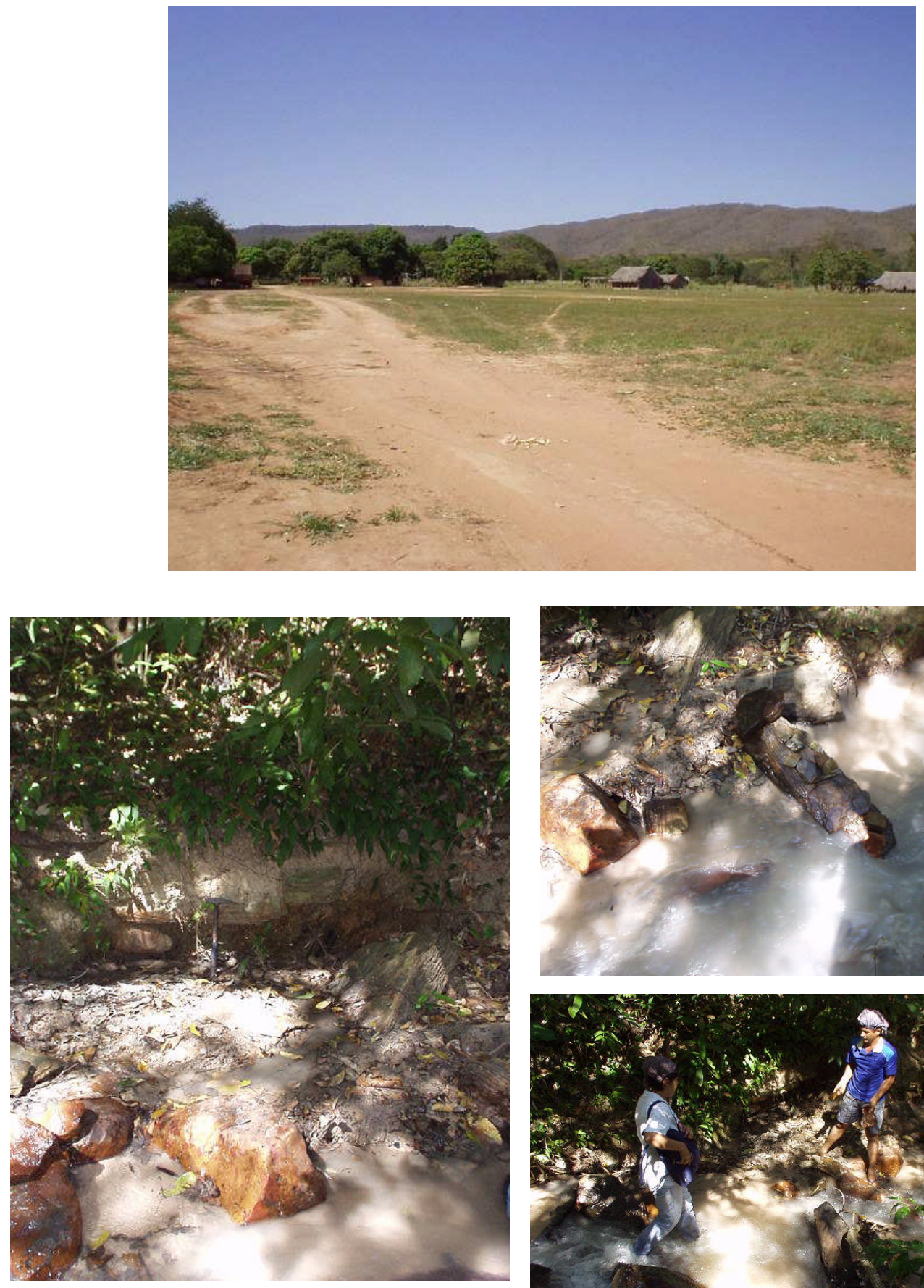

(63)

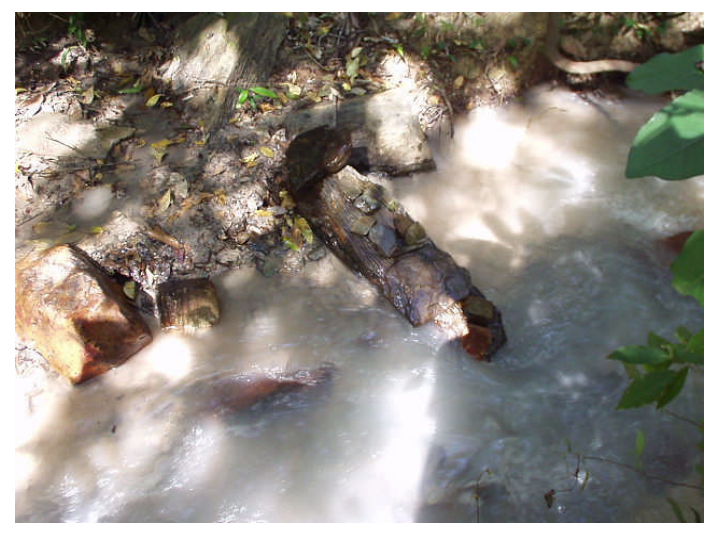

(61)

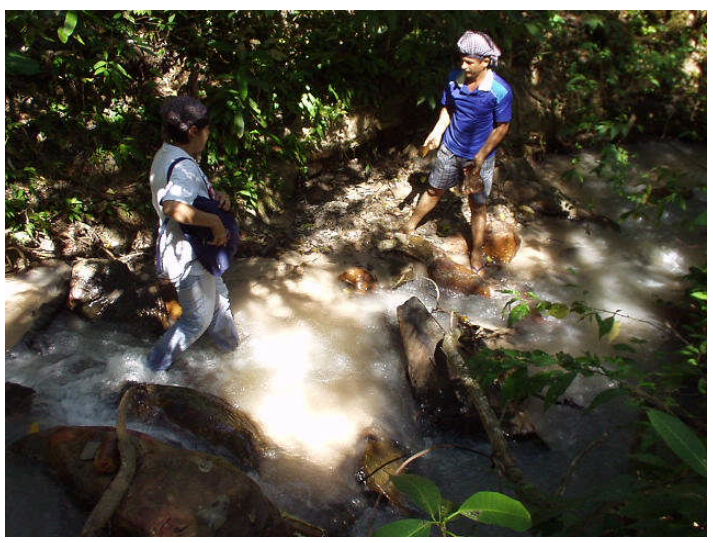

(62)

Figuras: (60) Vista da Aldeia Bororo Piegaba; (61, 62, 63) Afloramento visível devido à erosão provocada pela passagem do córrego Piegabre. 


\subsubsection{Minerais}

\section{$\Rightarrow$ Conjunto $\mathrm{H}$}

As hematitas que formam esse conjunto, praticamente não ocorrem na sua forma cristalina. São geralmente concentrações, produtos da desagregação do arenito que é enriquecido em ferro. Localizam-se em diversos pontos da área da Cidade de Pedra, geralmente associadas a drenagens secundárias, tal como a que passa próximo a Ferraz Egreja.
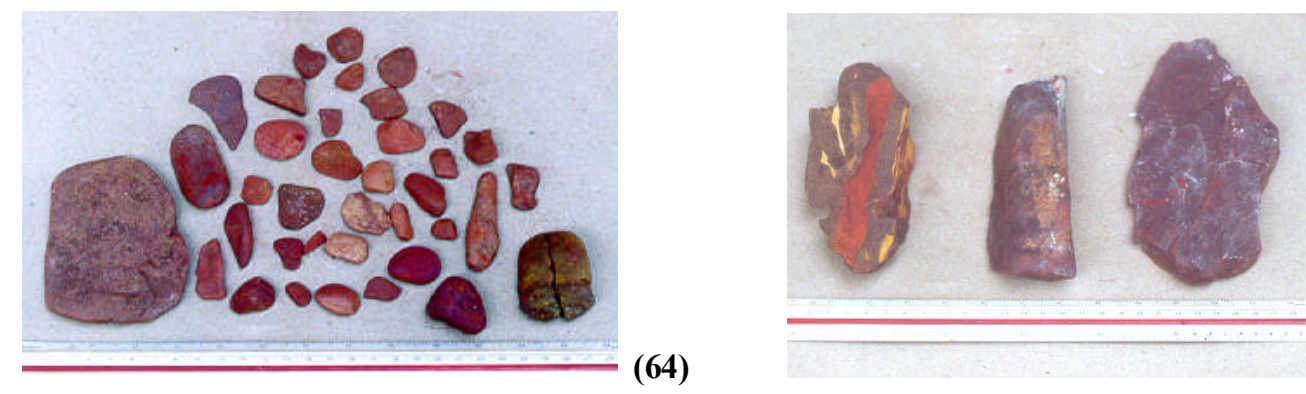

(65)

(64) Seixos/ plaquetas de hematitas, coletadas na drenagem, (65) ocorrência forma de carapaças ferruginosas na superfície do terreno.

\section{$\Rightarrow$ Conjunto I}

O quartzo pode ser encontrado na forma de seixos, ou mesmo, sem forma definida, associado aos afloramentos 3 e 4 (vide figuras 66 e 67). 
Figura 66. Sítios Arqueológicos em Estudo e Principais Afloramentos de Matéria-Prima (medidas aproximadas)
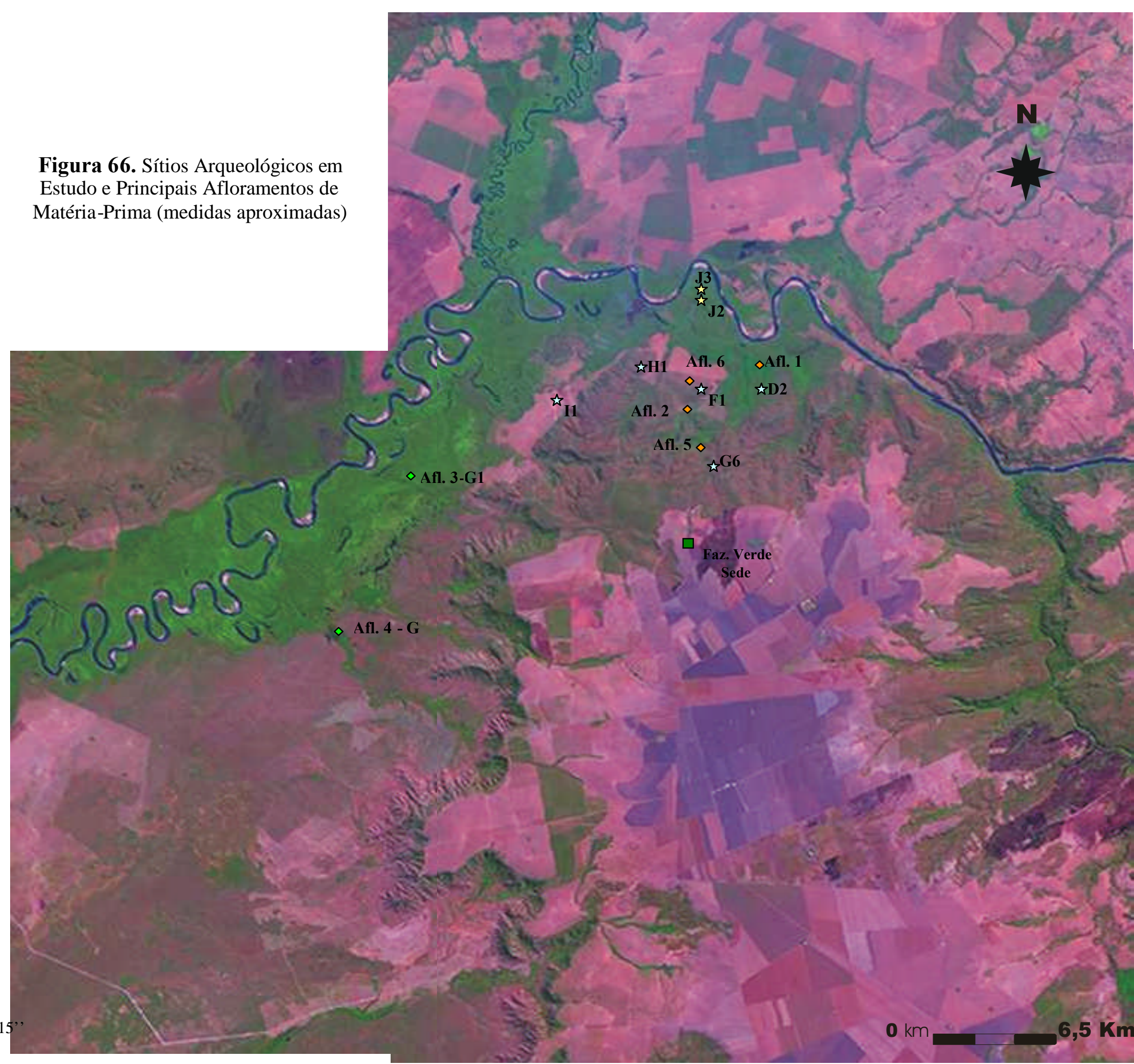

Legenda:

D2 Ferraz Egreja

F1 Antiqueira

G6 Abrigo Vermelhos

H1 Caverna do Cipó

11 Arqueiros

J2 Turbina

J3 Fazendinha

خ $\tau^{5}$ ítios em Abrigo

شSítios a céu aberto

$\diamond$ Afloramentos Conj. C C2

$\diamond$ Afloram Conj. G e G1

Fonte:

SE. 21-X-B-V

SE. 21-X-B-II

EMBRAPA Monitoramento por satélite, 2004 


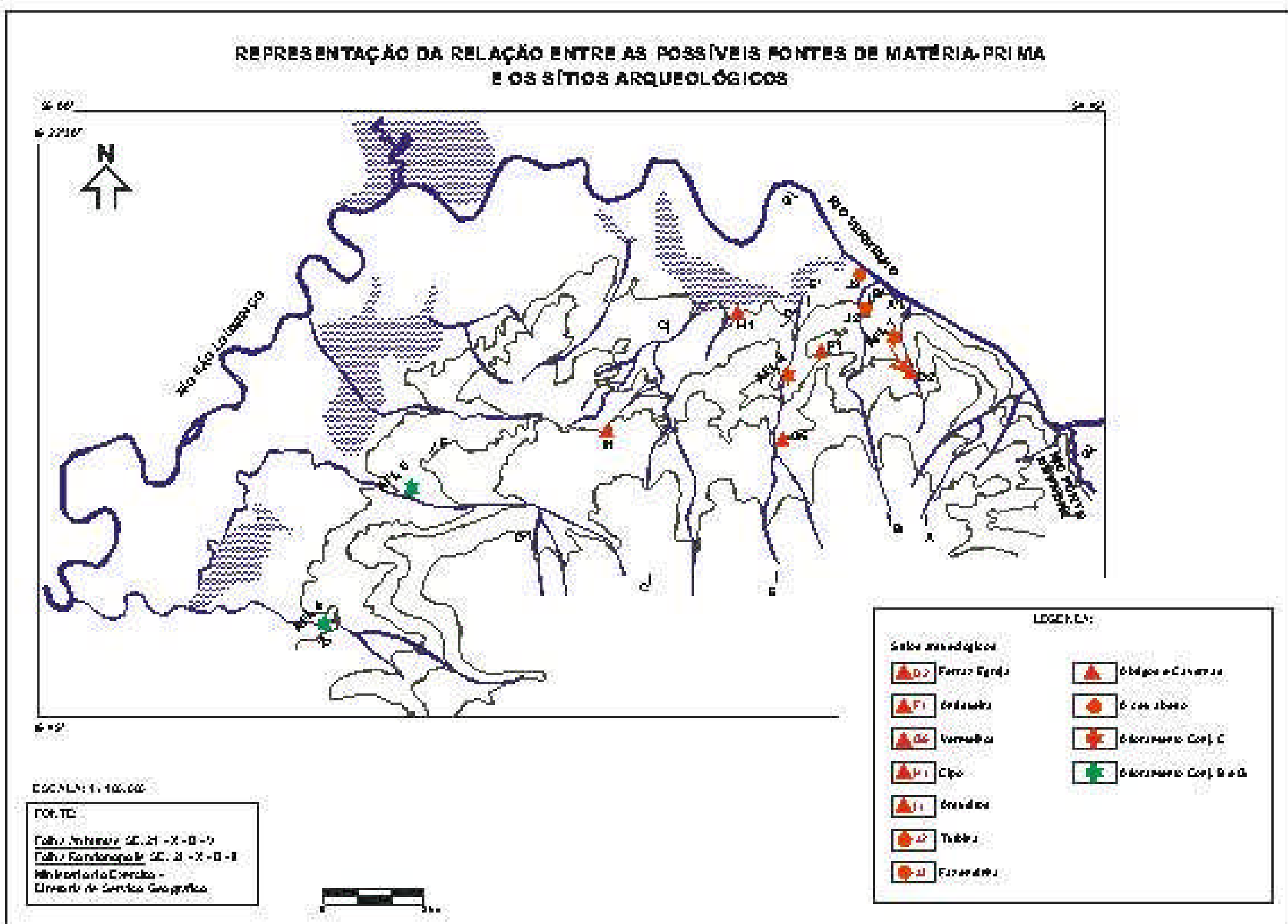




\section{Capítulo 5}

\section{O Aproveitamento das Matérias-Primas Líticas na Cidade de Pedra}

A análise da disponibilidade de matérias-primas líticas no ambiente de entorno aos sítios, a escolha dentre aquelas que estão disponíveis nas proximidades, a obtenção daquelas cujas fontes estão distantes do local de habitação, e a utilização dada a essas matérias-primas, compõem um conjunto de estratégias que se articulam com as demais atividades do grupo, direta ou indiretamente.

Cada sítio vai estar representado pela presença, intensa ou não, de um dado grupo cuja repetição e periodicidade de frequentação no habitat, vão dar indícios temporais dos períodos de ocupação, que irão permitir reconhecer uma população e sua área de circulação (Vilhena Vialou e Vialou, 2000, 2003).

\subsection{Sítio Arqueológico Ferraz Egreja}

O sítio arqueológico Ferraz Egreja começou a ser pesquisado em 1983, dando assim, origem as pesquisas na "Cidade de Pedra".Trata-se de uma formação arenítica residual, com uma forma grosseiramente cilíndrica com desgaste na base.

De acordo com Vilhena Vialou et al. (1999), as escavações realizadas colocam em evidência uma sucessão de ocupações, que abordam líticos pré-cerâmicos e líticos e cerâmicos, sendo que, as ocupações mais antigas são datadas em $4610 \pm 60$ e $3620 \pm 60$ BP.

Trata-se de um sítio em abrigo, que permite que todos os seus lados registrem atividades de ocupação, sejam nas paredes através de representações rupestres, seja no solo através de vestígios líticos, cerâmicos e demais estruturas.

O substrato rochoso que compões o abrigo é o arenito, sendo que esta base, parcialmente descoberta pelas escavações, é também formada de blocos caídos do teto do abrigo já bastante friável. A sedimentação é constituída de depósitos arenosos homogêneos, não havendo uma diferenciação estratigráfica no sentido pedológico de formação do solo. A cronoestratigrafia, estabelecida pelas superposições de ocupações quase que ininterruptas, faz com que se tenha identificado uma frequentação constante e 
intensa no abrigo num espaço de tempo de cinco milênios. (Vilhena Vialou e Vialou 1994, 1996,1999, 2000, 2003)

Os períodos mais antigos, entre 5000 e 2000 anos foram parcialmente escavados. São os níveis ceramistas que até agora, foram mais intensamente estudados e escavados, eles abrangem uma sucessão contínua de ocupações durante quase 2 milênios, período este, registrado por uma fogueira de forma circular, bem estruturada e com fragmentos cerâmicos, datada de 1900 anos atrás. (Vilhena Vialou e Vialou 1999, 2000, 2003).

De maneira geral, a presença cerâmica em relação ao material lítico é reduzida, são cerca 1500 fragmentos. Ela é marcada por uma variedade de recipientes de pequenas dimensões com decorações (pintada e incisa) e bordas diversificadas. Não há tigelas grandes nem fragmentos espessos pertencentes a peças de tamanho grande.

A interação, povo ceramista e artesão lítico, parece estar intimamente ligada e é repetitiva ao longo do tempo, desde os primórdios do aparecimento da cerâmica na região, 1900 anos $\mathrm{BP}$ até os últimos moradores do abrigo entre 400 e 200 anos BP (Vilhena Vialou e Vialou 1994, 2003).

De acordo com Vilhena Vialou e Vialou (1994, 1996,1999, 2000, 2003) a organização do espaço em setores norte, sul e oeste são complementares, já que a unidade doméstica não ficou limitada a um dos setores, há uma distribuição espacial de atividades permitindo uma rotação no abrigo. O setor sul (FE II) é marcado pela presença de concentrações de rochas, por vezes, estruturando grandes fogueiras relacionadas a atividades culinárias, é uma área que fica protegida do sol a maior parte do dia, sendo também caracterizada pelas atividades de lascamento. No setor oeste (FE III) as atividades de lascamento também se fazem presentes, além de ser a área mais escondida do abrigo devido ao teto mais baixo. Ferraz Egreja é um abrigo cilíndrico e os grupos que ali habitaram dispunham de uma abertura de $360^{\circ}$, que poderia ser utilizada segundo as estações, ou o ciclo solar e noturno. As implantações sincrônicas no abrigo (por exemplo, unidades familiares) podem não ser ligadas espacialmente. No decorrer dos milênios em função das modificações climáticas, a localização das ocupações podem ter girado em torno do abrigo provocando lacunas arqueológicas nas sequiências cronoestratigráficas (Vilhena Vialou, 1992-1993). 
Tabela 3. Quadro cronológico dos sítios arqueológicos da Cidade de Pedra

\begin{tabular}{|c|c|c|c|c|c|c|}
\hline & Ferraz Egreja & Vermelhos & Cipó & Arqueiros & Antiqueira & Fazendinha \\
\hline \multicolumn{7}{|l|}{ Períodos } \\
\hline Cerâmico & $\begin{array}{c}205+/-40 \text { Gif-10047 } \\
420+/-40 \text { Gif-10044 } \\
780+/-20 \text { Gif-10048 } \\
1060+/-40 \text { Gif- } 10048 \\
1260+/-40 \text { Gif-9645 } \\
1340+/-50 \text { Gif-9046 } \\
1470+/-40 \text { Gif-9699 } \\
1570+/-50 \text { Gif-7878 } \\
1700+/-50 \text { Gif-7087 } \\
1900+/-40 \text { Gif-9697 }\end{array}$ & $\begin{array}{l}\text { 1250+/-80 Gif-8663 } \\
1470+/-40 \text { Gif-9700 } \\
\text { 1890+/-50 Gif-9703 }\end{array}$ & 1025+/- FATEC Tl & 1095+/-35 Gif-11727 & $645+/-45$ Gif-11731 & $\begin{array}{l}600 \mathrm{BP} \\
800 \mathrm{BP}\end{array}$ \\
\hline Pré-Cerâmico & $\begin{array}{l}2110+/-120 \text { Gif-6712 } \\
2200+/-40 \text { Gif-7087 } \\
2700+/-40 \text { Gif- } 10052 \\
\\
3620+/-60 \text { Gif-6248 } \\
4610+/-60 \text { Gif-6249 }\end{array}$ & $\begin{array}{l}\text { 2030+/-40 Gif- } 9701 \\
2455+/-60 \text { Gif- } 11434 \\
2800+/-35 \text { Gif- } 11435 \\
3400+/-40 \text { Gif- } 11436 \\
3705+/-40 \text { Gif- } 11433\end{array}$ & & & & \\
\hline
\end{tabular}




\subsubsection{O Aproveitamento da Matéria-Prima Lítica}

De acordo com os estudos realizados por Vilhena Vialou (no prelo), quase todas as etapas referentes ao preparo dos utensílios em arenito (conjuntos A,B,C,D), quartzito (conjunto C2) e sílex (conjuntos E,F), são encontradas no próprio sítio. A autora ressalta ainda que não há presença de grandes peças, os blocos e grandes seixos que serviram de matrizes aos lascamentos já vieram reduzidos, sendo tal fato comprovado pela ausência de grandes lascas corticais.

Segundo a autora, os pequenos seixos-núcleos foram percutidos em posição inclinada por meio de golpes secos por outros seixos-percutores, também pequenos, de forma que podem ser contidos por uma das mãos. Os talões das lascas e das estilhas são finos, lineares, e com presença de bulbo, formam regularmente um ângulo de $110^{\circ}$ a $140^{\circ}$, sendo propício para retirada de lascas finas e relativamente alongadas. Os núcleos e fragmentos de núcleo são geralmente globulosos, sem uma orientação particular no preparo do plano de percussão.

As rochas metamórficas (Conjunto G,G1), devido as suas propriedades petrográficas, lasca-se mal e fragmenta-se facilmente, porém existem numerosos fragmentos em todo o abrigo, indicando o trabalho de lascamento efetuado em grandes blocos de matéria-prima. Essa rocha foi empregada para confecção de objetos polidos, a ocorrência de grandes peças, semi-lascadas e semi-polidas, mostram que elas foram desbastadas in loco, até chegar na forma desejada, então era efetuado polimento como acabamento. No caso das rochas mais friáveis, que não são consistentes, a forma do objeto não ficou preservada, e as fragmentações se desfazem ao tocar (Vilhena Vialou, no prelo).

A autora comenta que, salvo o quartzito, onde as lascas giram em torno de $4 \mathrm{~cm}$, tanto no comprimento como na largura, as demais rochas não chegam a isso. O sílex tem proporções de lascas alongadas e finas, enquanto que as nas lascas de arenito (conjuntos A,B,C,D), as dimensões de comprimento e largura são próximas, em torno de $3 \mathrm{~cm}$. Nas rochas metamórficas (conjuntos G1,G2) as lascas são mais largas que longas Uma constante para todas essas rochas, é a espessura, que fica em torno de $1 \mathrm{~cm}$.

A média do tamanho para as estilhas, é de $1,1 \mathrm{~cm}$ para o sílex, 1,3 cm para o arenito (conjuntos A,B,C,D) e de 1,5 cm para as rochas metamórficas (conjunto G1,G2), 
as larguras são proporcionalmente semelhantes e as espessuras estão em torno de 0,3 $\mathrm{cm}$. Este material está vinculado ao preparo do utensílio, sendo na sua maioria, retiradas de retoque.

Os fragmentos de lascamento são de dimensões intermediárias entre as lascas e as estilhas, 2 a $3 \mathrm{~cm}$, sendo estes, produtos do preparo do lascamento e não da fragmentação de lascas.

Os utensílios feitos sobre lasca foram intensamente utilizados. Os raspadores de retoques em escamas, os raspadores de retoques lamelares, as peças com reentrâncias, os denticulados, as peças com retoques bifaciais e as lascas retocadas compõem os tipos de utensílios identificados, ocorrem também nas lascas desprovidas de retoques marcas de utilização, sendo estas representadas pelos micro retoques de desgaste, denteamento, lustro e polimento do bordo ativo. Por fim, a autora conclui que o tipo de rocha não modificou o padrão de lascamento (Vilhena Vialou, no prelo).

O quartzo é pouco presente no abrigo, nos raros casos em que ocorre, parecem estar relacionados a adornos, espécie de pingentes.

Outro mineral é a hematita, que muitas vezes está associada a outros minerais de ferro, ao contrário do quartzo, é proporcionalmente muito abundante nos sítios, ocorrem em todos os momentos e localidades do habitat, havendo entretanto zonas de maiores concentrações onde elas teriam sido armazenadas. Uma de suas fontes encontra-se no fundo do córrego a 10 metros do abrigo.

Essa matéria-prima foi utilizada como pigmento, através de sua abrasão se obtem o pó a partir do qual foram realizadas as representações rupestres. Além dessa utilização, as plaquetas de hematita também tiveram outro preparo e uso, em algumas delas foram confeccionados adornos, provavelmente, uma espécie de pingente. São peças isoladas com características singulares quanto a forma, o tamanho e a técnica de produção, sendo assim, não se trataria de contas de colar onde a repetição da confecção é necessária (Vilhena Vialou, no prelo).

Com a finalidade de representar essa relação entre classes líticas e matéria-prima lítica, foram gerados histogramas de freqüência. No caso de Ferraz Egreja, estas relações foram analisadas respeitando os diferentes espaços de ocupação ao redor do abrigo. 


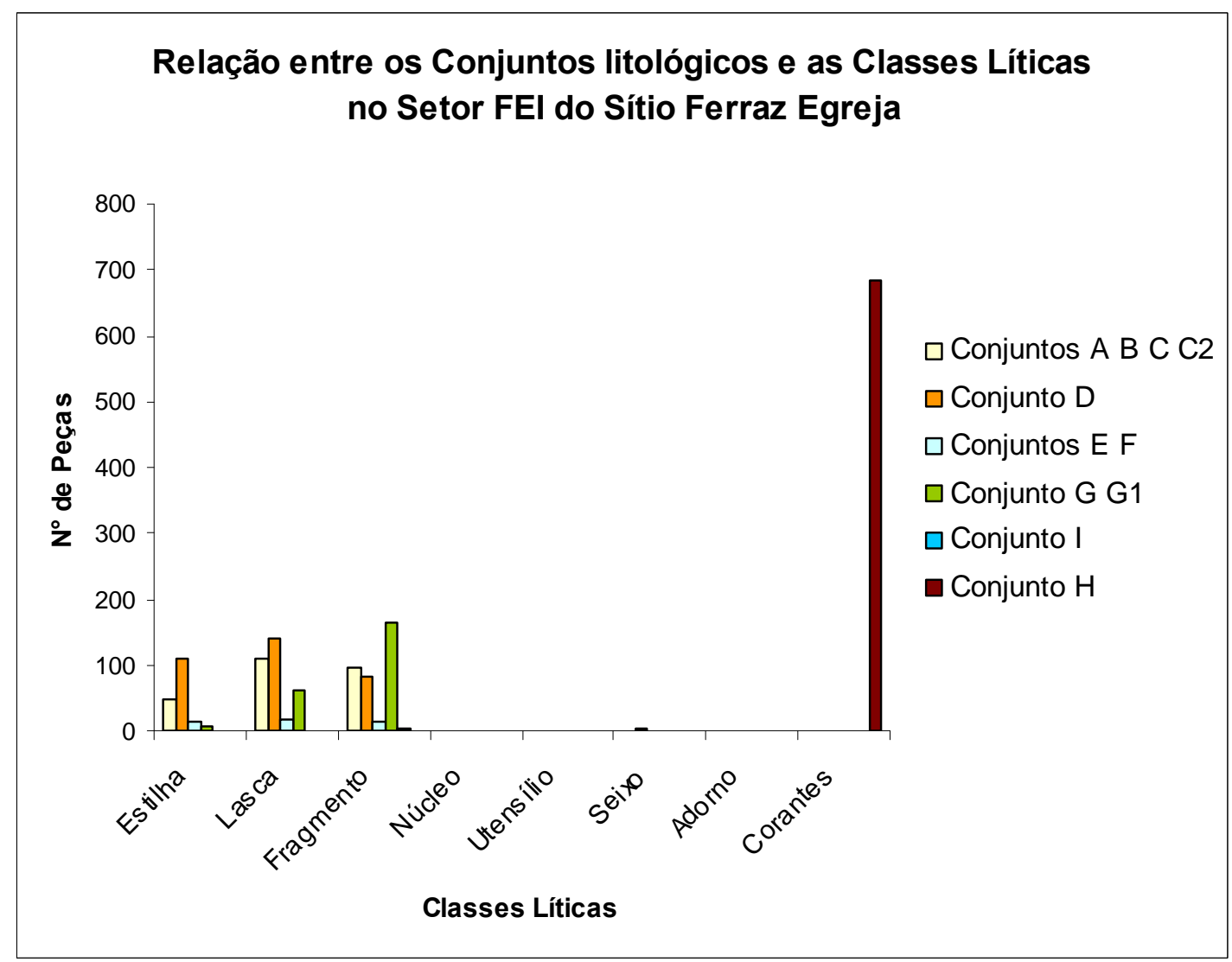

Gráfico 1. Histograma representando a variação dos conjuntos litológicos entre as classes líticas do setor FEI do sítio Ferraz Egreja.

O gráfico 1 demonstra a totalidade do material lítico que ocorre em 32 quadras do setor FEI, onde uma área de $45 \mathrm{~m}^{2}$ e aproximadamente $50 \mathrm{~cm}$ de profundidade foi escavada. A grande maioria do material está representada por hematitas e arenitos extremamente enriquecidos em ferro, que entram na categoria corante. Os conjuntos $\mathrm{A}$, $\mathrm{B}$ e C, que representam a variedade de arenitos foram agrupados, relacionando os arenitos de origem primária, que junto ao conjunto $\mathrm{D}$, são as principais rochas utilizadas no lascamento, associados fundamentalmente a lascas, fragmentos e estilhas.

O conjunto $\mathrm{G}$, representado pelas rochas metamórficas, está relacionados principalmente a fragmentos na forma de plaquetas, que corresponde ao seu plano natural de fraturamento, em menor quantidade, estão as lascas. O conjunto de silexitos tem uma freqüência registrada muito inferior aos arenitos e rochas metamórficas. 
Os núcleos presentes estão sempre associados aos conjunto D e E, já os utensílios ocorrem entre os conjuntos, A, B, D, E e G. No caso do conjunto G, de rochas metamórficas, tanto as rochas mais compactas, como as rochas mais friáveis (quartzograuvacas) foram utilizados, inclusive na confecção de bifaces. No caso das rochas metamórficas, sabe-se, através de toda a análise realizada em campo e laboratório, que o fato de encontrá-los nas escavações com aspecto friável se deve a ações de intempirismo pós-deposicional, mas que na área de coleta era uma rocha com alta dureza, já os quartzo-grauvacas são naturalmente muito mais frágeis por apresentarem estruturas de foliação, ainda assim são encontradas peças trabalhadas nessa rocha.

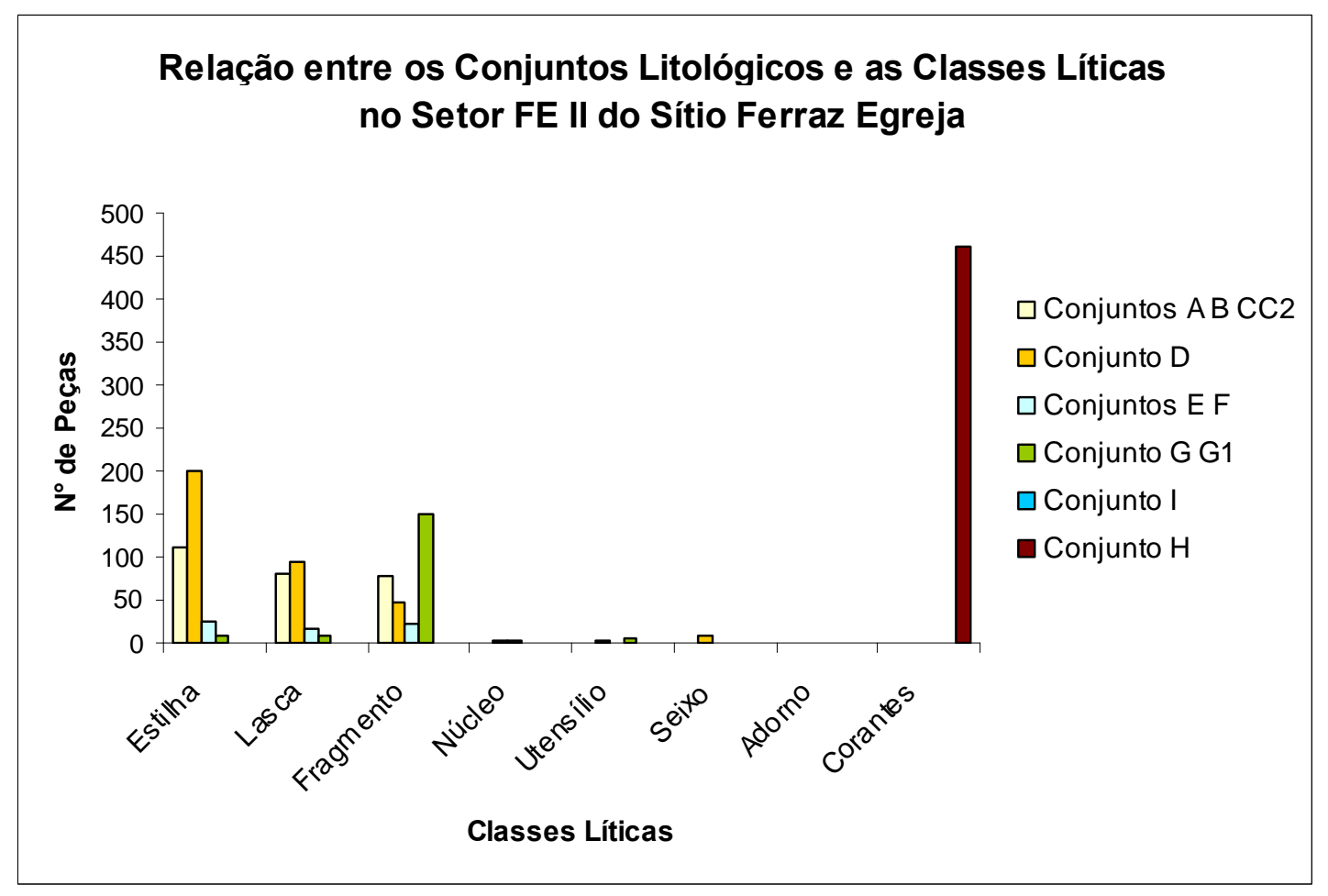

Gráfico 2. Histograma representando a variação dos conjuntos litológicos entre as classes líticas do setor FEII do sítio Ferraz Egreja.

O gráfico 2 está representando o material recuperado nas escavações de 10 quadras do setor FEII do sítio Ferraz Egreja, quadras estão associadas a fogueiras cujos carvões foram datados. Essa área corresponde a $10 \mathrm{~m}^{2}$ da área total escavada, que é de 
$75 \mathrm{~m}^{2}$ com uma profundidade aproximada de $150 \mathrm{~cm}$. O gráfico representa a freqüência geral do setor, onde, assim como no setor I, os corantes são predominantes. Os arenitos também ocorrem em grande maioria associados a lascamento, majoritariamente representados por estilhas, seguido de lascas e fragmentos e raros utensílios.

A rocha metamórfica, como lhe é característico, ocorre associada principalmente a fragmentos, sendo superior aos fragmentos de arenito.

O conjunto I, dos silexitos, mantém um padrão de ocorrência sempre muito inferior ao dos arenitos, associado a pequenos fragmentos e lascas

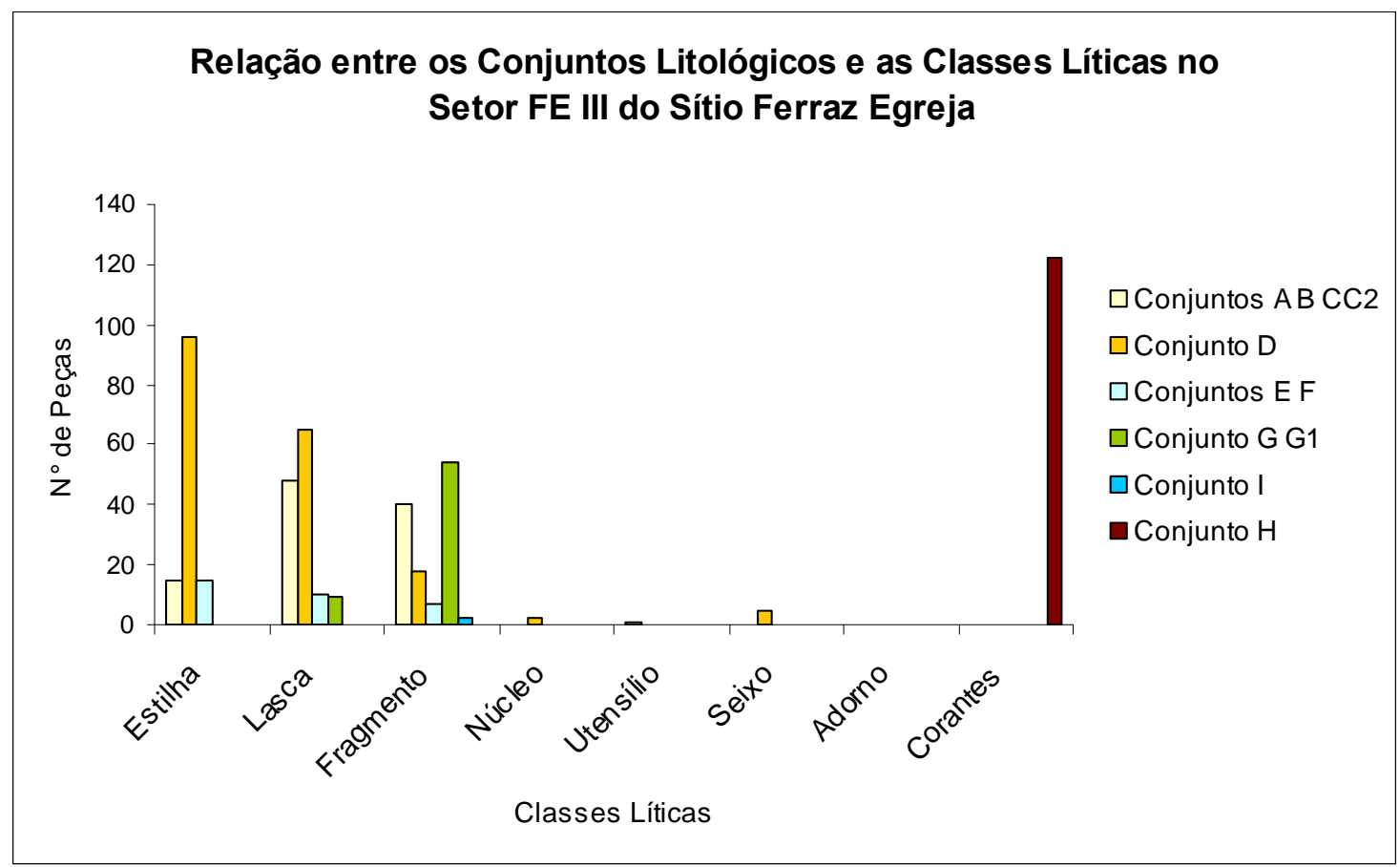

Gráfico 3. Histograma representando a variação dos conjuntos litológicos entre as classes líticas do setor FEIII do sítio Ferraz Egreja.

O gráfico 3. representa a variação dos conjuntos litológicos em relação as classes líticas, verificando-se nítidas semelhanças com as freqüências recorrente nos setores FEI e FEII, caracterizada pela predominância de corantes seguido de arenitos associados a lascamento, com a diferença que nesse setor, lascas e estilhas são praticamente equivalentes. As rochas metamórficas se destacam em número pelas peças 
fragmentadas, havendo também a ocorrência de bifaces. Os conjuntos de silexitos mantém o mesmo padrão.

O sítio Ferraz Egreja é um exemplo de abrigo-habitat, de implantação duradoura e repetitiva, intensa e sem grandes mudanças culturais aparentes (Vilhena Vialou e Vialou, 2000, 2003). Isso fica evidenciado também na utilização da matéria-prima e na preferência por determinadas litologias, que não necessariamente estão relacionadas a possíveis facilidades na coleta.

\subsection{Sítio Arqueológico Abrigo Vermelhos}

Esse abrigo fora descoberto durante as prospecções de 1990, e segundo Paillet (1995) trata-se de um dos mais notáveis e ricos complexos iconográficos, com cerca de 540 unidades de grafismos.

A área do sítio está situada na borda ocidental da Cidade de Pedra, a menos de $10 \mathrm{~km}$ do sítio Ferraz Egreja, e da mesma forma, é caracterizado pela presença de afloramentos areníticos residuais ruiniformes.

De Blasis (1993), descreve esse sítio como sendo um grande e multifacetado afloramento arenítico, onde podem ser vistos vários painéis de pinturas rupestres, distribuídos pela maior parte das paredes laterais, que formam pequenos abrigos. A erosão diferencial do afloramento rochoso e o basculamento de um de seus lados, criaram no abrigo um amplo e espaçoso salão central, bem sombreado todo o dia. É justamente nessa porção do sítio onde ocorrem com maior intensidade o uso das paredes nas representações rupestres e onde também foi detectada concentração de vestígios no solo que confirmam o uso intensivo desse espaço interno do abrigo.

Paillet (1998) descreve ainda que as primeiras sondagens foram efetuadas em 1991 e 1992 nessa porção central do sítio (área totalmente abrigada), e colocaram em evidência a presença arqueológica (indústria lítica, fragmentos de cerâmica, carvão). Uma primeira datação pelo Carbono 14, forneceu para os níveis superficiais uma idade de $1250 \pm 80$ BP (Gif 8662). Essa margem de tempo de níveis ocupacionais é bem semelhante ao sítio de Ferraz Egreja, indo de períodos lito-cerâmicos de até 500 anos 
BP até níveis líticos de 4100 anos BP (ver tabela 3). O número de fragmentos cerâmicos é reduzido, se comparado aos outros sítios da região do "período ceramista".

A área decapada é de $15 \mathrm{~m}^{2}$, o sedimento é arenoso e homogêneo até a proximidade da base do sítio que repousa sobre um substrato rochoso em arenito, de topografia irregular, essa base irregular fez com que a profundidade da área escavada variasse bastante, entre 30 e $80 \mathrm{~cm}$ em relação a superfície. As evidências arqueológicas presentes no sedimento consistem, sobretudo, em vestígios de atividades de lascamento e combustão, tendo sido encontrados também vários corantes e alguns poucos fragmentos cerâmicos. Fragmentos de carvão eram abundantes e dispersos no sedimento, indicando a presença de fogo por um lado, e sugerindo por outro, a presença de processos naturais de dispersão destes vestígios, ainda assim há numerosas estruturas de combustão bem conservadas no espaço habitacional (De Blasis, 1993; Vilhena Vialou, 1994,1996). Um total de 1850 objetos, foram cadastrados nesse sítio, destes, $1529(83 \%)$ correspondem a material lítico, 251 (14\%) são corantes e $9(0,5 \%)$ são fragmentos cerâmicos (Blasis, 1993).

Cabe ressaltar ainda que o abrigo Vermelhos encontra-se próximo a vários outros sítios rupestres, como o abrigo Selos, Anões e Mãos, além disso, em poucas horas pode-se alcançar a Cidade de Pedra e, atravessando-a chega-se a Ferraz Egreja. O rio Vermelho e seus terraços encontram-se a cerca de $6 \mathrm{~km}$ descendo o vale.

\subsubsection{O Aproveitamento da Matéria-Prima Lítica}

Foram escavados $20 \mathrm{~m}^{2}$ desse sítio e a matéria-prima do lítico recuperado, foi parcialmente analisada. Segundo as primeiras análises realizadas por De Blasis (1993), a indústria lascada é algo diversificada, tanto em termos de matérias-primas como em relação às categorias tecnológicas. A maior parte do material é refugo de lascamento, havendo pouquíssimos artefatos com retoques claros e formatos evidentes, basicamente raspadores. As lascas são bastante preparadas, e as numerosas estilhas sugerem a presença de uma tecnologia mais refinada apesar do aspecto bruto do material lítico em arenito (conjunto B, C, C2), especialmente. Segundo o autor, as escassas evidências de uso, associadas à baixa frequiência de artefatos, sugerem que a grande maioria dos vestígios líticos encontrados no solo do abrigo são, sobretudo, refugos de lascamento. 
Associado a esse dado, está a quase ausência de peças corticais (7\% do material), sugerindo que o descorticamento foi feito em outro sítio, ou então nas áreas mais externas do abrigo. Cabe comentar ainda a ação de alteração térmica, identificada em 53\% dos vestígios líticos catalogados. De acordo com De Blasis (1993), embora tais evidências possam ser atribuídas ao uso de técnicas de tratamento térmico das matériasprimas, parece certo que grande parte da queima da debitagem está associada à grande quantidade de vestígios de combustão presentes no sedimento do abrigo.

A matéria-prima predominante é o arenito (conjuntos A,C), compondo cerca de $43 \%$ da amostra, já os arenitos do conjunto D, perfazem cerca de $28 \%$ do material. A variedade de silexitos (conjuntos E,F) vem em seguida compondo cerca de $18 \%$ da amostra, enquanto que as rochas metamórficas dos conjuntos G e G1 agrupam $6 \%$. Finalmente, os quartzitos (conjunto $\mathrm{C} 2$ ) e quartzos compõem 5\% do total do material lítico. As lascas, estilhas e utensílios estão principalmente associadas as rochas do conjunto D.

As rochas metamórficas dos conjuntos G e G1 que compõe 98 peças do sítio, foram analisadas previamente por De Blasis, que identificou um lascamento indiscutível em cerca de $30 \%$ do material, apesar de aptidão mínima ao lascamento, no entanto, como em Ferraz Egreja, o tratamento dada a essa matéria-prima indica desbaste e descorticamento, sugerindo que estas estejam associadas a produção de artefatos polidos.

\subsection{Sítio Arqueológico Arqueiros}

Este abrigo está situado mais próximo ao platô, longe de fonte de água, encontra-se mais afastado do conjunto de sítios da Cidade de Pedra, mas não está completamente isolado, a cerca de $1 \mathrm{~km}$ há outro sítio com representações rupestres, o sítio Pacifico. Trata-se de um abrigo rupestre formado por um paredão retilíneo coberto por pinturas, delimitando o espaço habitacional.

Esse sítio começou a ser escavado no ano de 2001, quando foi aberta uma sondagem de $4 \mathrm{~m}^{2}$ onde foram registrados vestígios arqueológicos, representados por estruturas de combustão, lascas, lâminas de machado, hematitas e cerâmicas. As 
escavações prosseguiram e até 2004 a área escavada era de $24 \mathrm{~m}^{2}$, a espessura do pacote sedimentar é em média de $20 \mathrm{~cm}$, composta por sedimento arenoso que está depositado diretamente sobre a base do sítio, formada pelo próprio arenito (Vialou e Vilhena Vialou, 2004).

Duas datações foram obtidas para essa ocupação, 1035+/-35 BP e 1095+/-35 BP, que correspondem as instalações dentro de um período de tempo limitado.

\section{Propor ção do Material Ar queológico no Sítio Arqueiros}

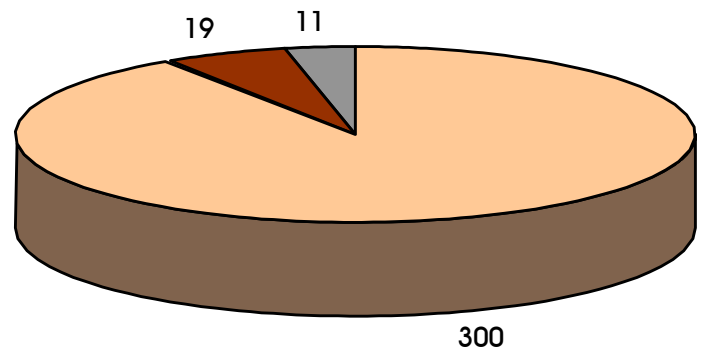

$\square$ Lítico

$\square$ Cerâmica

पMaterial orgânico

Gráfico 4.. Representação quantitativa dos vestígios arqueológicos do sítio Arqueiros

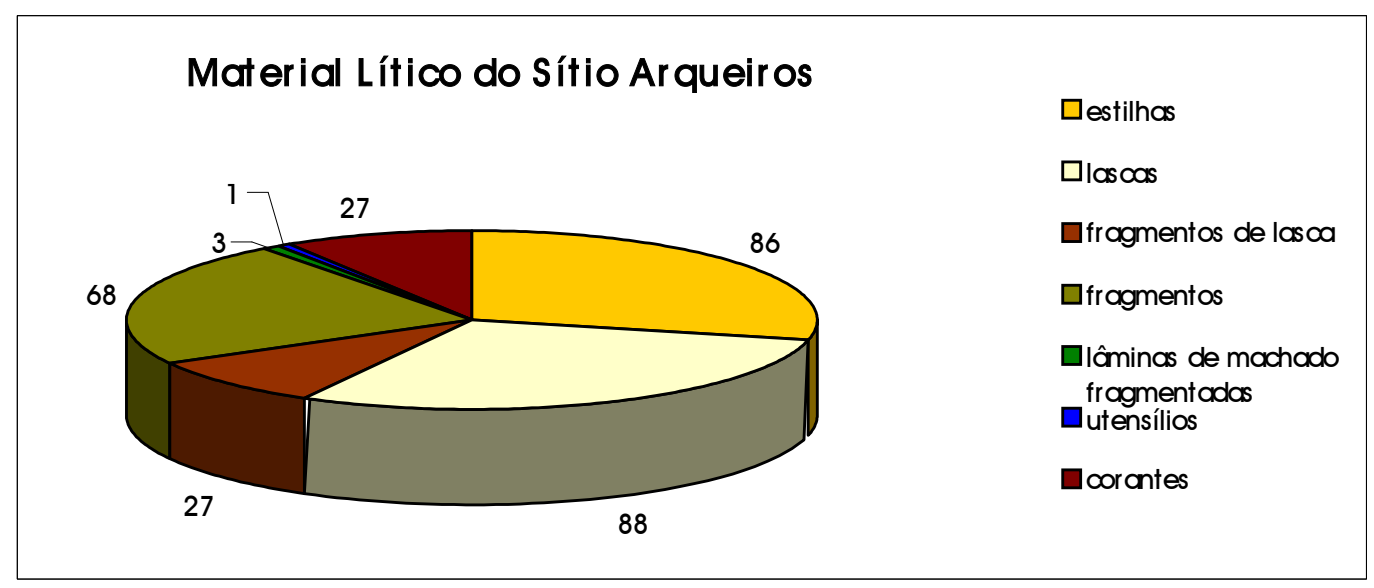

Gráfico 5. Representação quantitativa dos vestígios líticos do sítio Arqueiros 


\subsubsection{O Aproveitamento da Matéria-Prima}

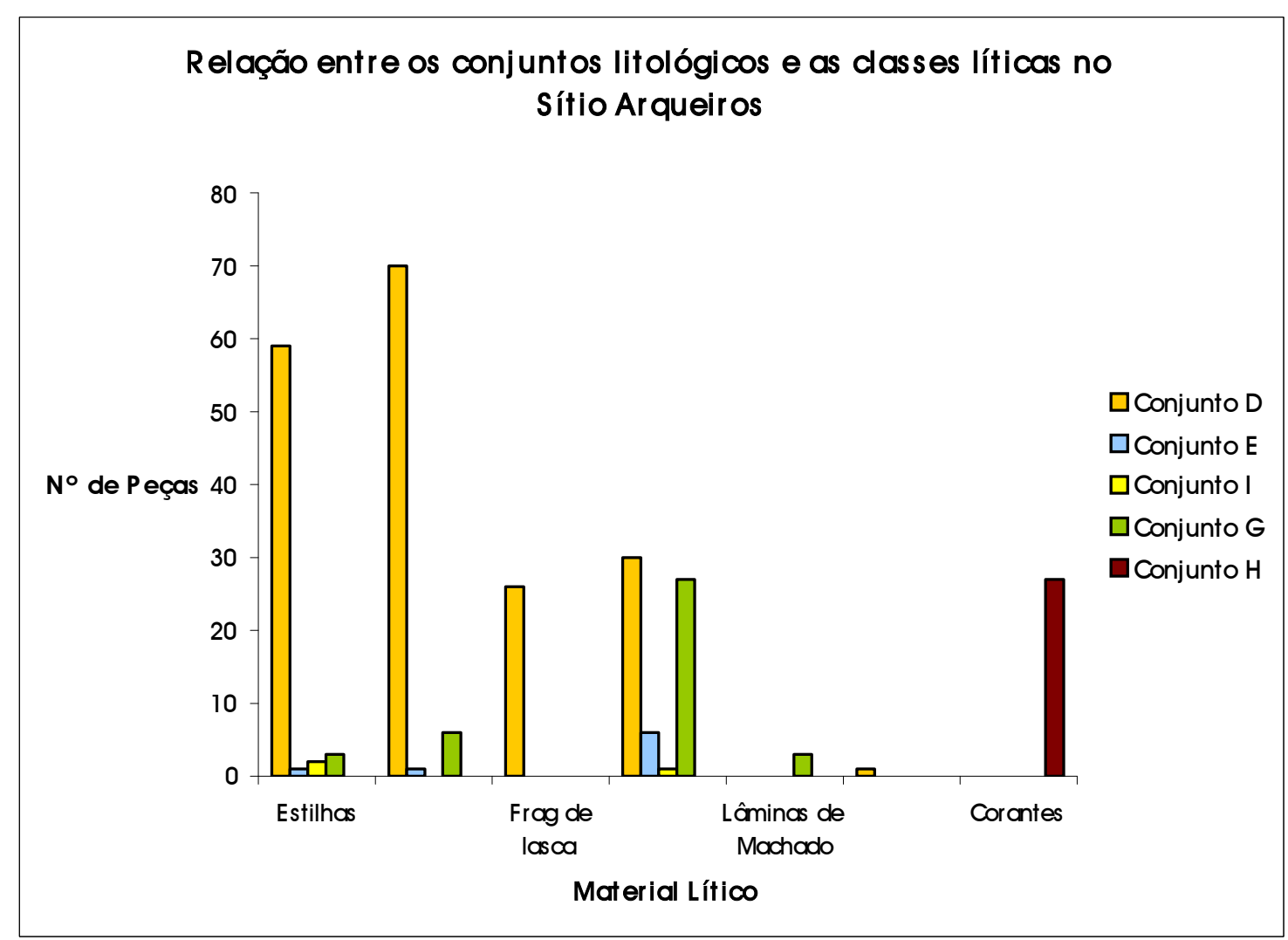

Gráfico 6. Histograma representando a relação entre os conjuntos litológicos e as classes líticas no sítio Arqueiros

O gráfico acima demonstra a variedade de matérias-primas presente no sítio, consiste basicamente na exploração de seixos de arenito silicificado provenientes do rio Vermelho (conjunto D) e que é encontrado no sítio principalmente como lascas e estilhas. Os fragmentos de rochas metamórficas do conjunto G, mais especificamente, são freqüentes como fragmentos e de maneira reduzida como lascas e estilhas, sendo representados também por fragmentos de lâminas de machado polida. A presença dessas lascas e estilhas próximas a fragmentos de prováveis lâminas de machado, podem indicar um preparo realizado no próprio local (Vialou e Vilhena Vialou, 2003). O conjunto E ocorre em menor quantidade, associados a estilhas, lascas e fragmentos, já os corantes não são tão representativos como em outros sítios. Há lugares para coleta desse material nas proximidades, principalmente em bolsões por onde antigamente 
deviam passar córregos, considerando o aspecto erodido da superfície dos afloramentos de arenito.

Os vestígios arqueológicos presentes nesse sítio revelam um conjunto de atividades realizadas no próprio local, tais atividades parecem ter sido o produto de várias breves passagens, que por sua vez, estariam relacionadas a um período limitado que corresponde as demais ocupações na Cidade de Pedra (Vialou e Vilhena Vialou, 2004).

\subsection{Sítio Arqueológico Caverna Antiqueira}

Esse sítio arqueológico é uma caverna em arenito com presença de representações rupestres, está situado entre o platô e a baixada. Essa caverna não foi totalmente explorada, sendo o acesso principal apenas ao primeiro salão que compõem uma área ampla e com topografia regular, apresenta um teto alto, em forma de abóboda. Este salão está ligado a outro salão, já na obscuridade total, essa ligação é feita por uma pequena abertura, através da qual só se passa com o corpo inclinado.

A abertura da caverna está exposta para o lado sul, mas está localizada na base de um paredão rochoso em arenito, em um fundo de vale, isso faz com que haja pouca penetração de raios solares. De acordo com Vilhena Vialou e Vialou (2000, 2003), esses elementos de localização, exposição solar e topografia condicionam o tipo de ocupação.

Os vestígios de dois níveis identificados revelam um sítio de poucas visitas e não de instalação permanente que pode ter sido local de rituais. Os vestígios são escassos, poucos e espessos fragmentos cerâmicos foram reconstituídos dando forma a uma grande tigela. Os lítico, apesar da pouca quantidade, são selecionados e expressivos em volume, refletidos, por exemplo, nas quatro lâminas de machado encontradas dispostas num espaço de $2 \mathrm{~m}^{2}$ de um mesmo solo arqueológico. As representações rupestres são também especiais, seja pelos temas escolhidos, representações figurativas de animais, seja pelo estilo, utilização de pigmento branco, raro nos demais abrigos da região. Duas datas situam esses níveis mais recentes, 645 e 800 anos atrás, subjacentes a $40 \mathrm{~cm}$ de sedimento superficial estéril. 


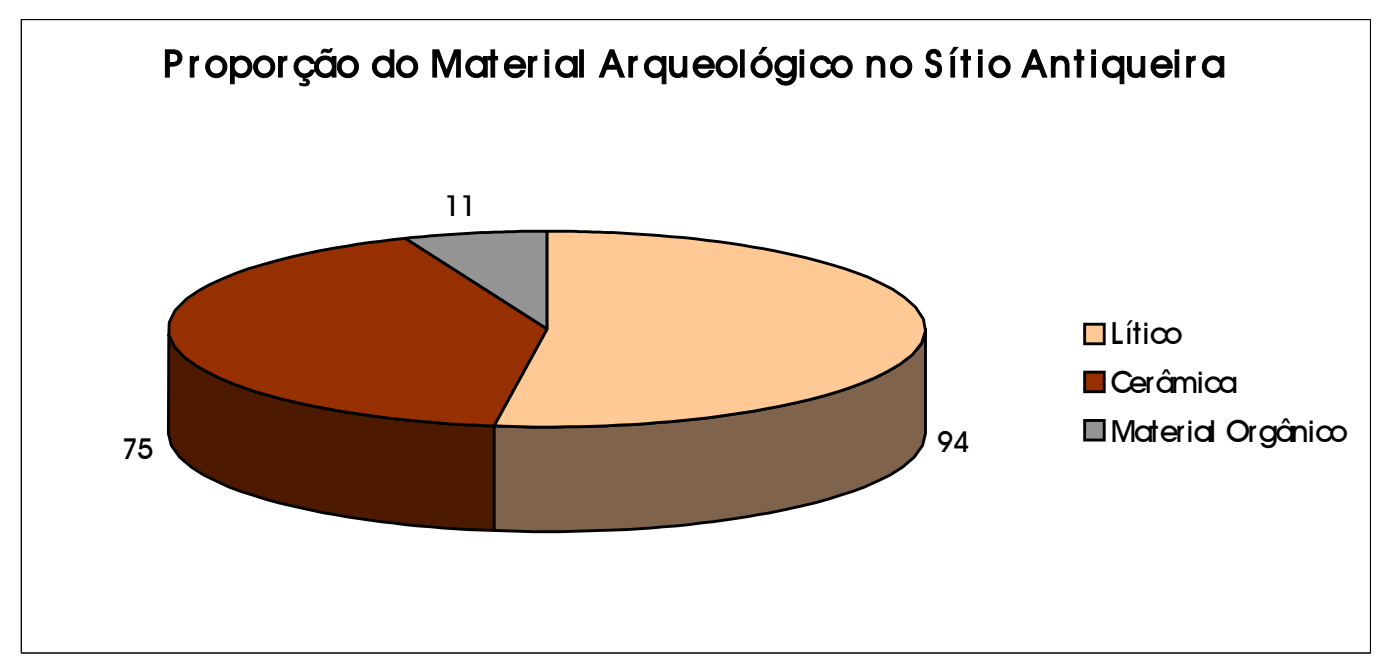

Gráfico 7. Representação da relação quantitativa do material arqueológico no sítio Antiqueira

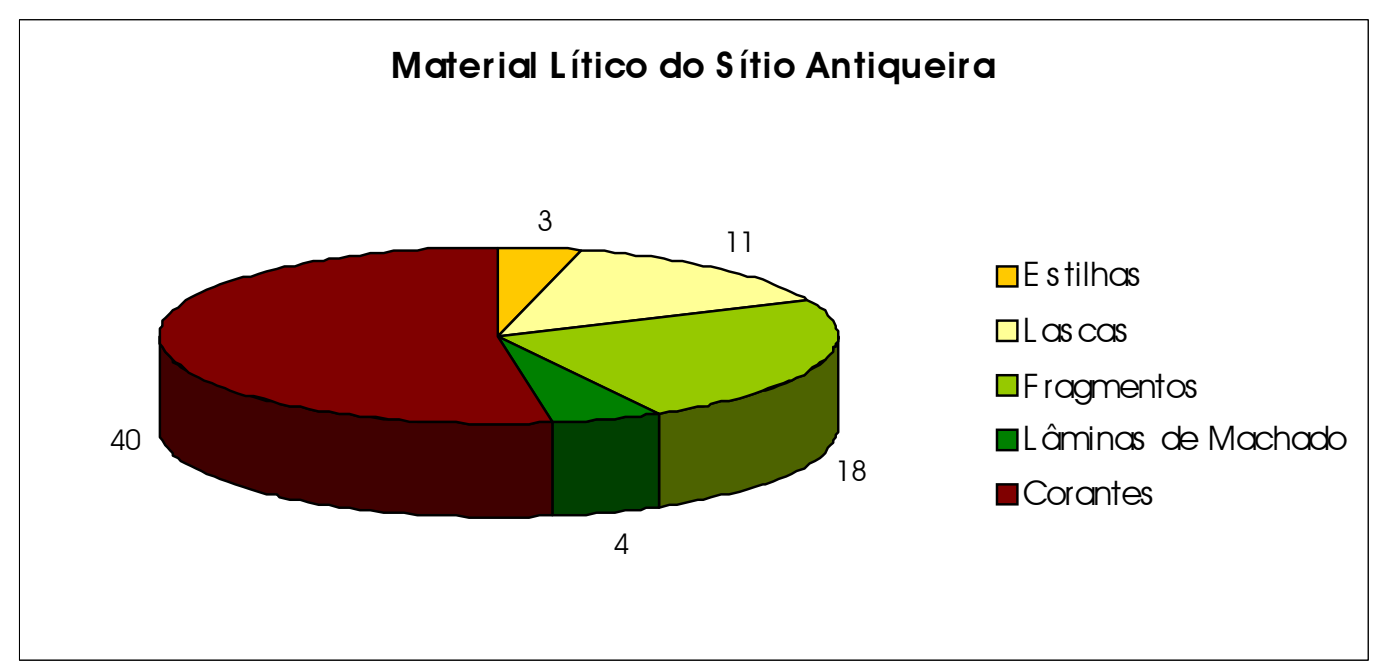

Gráfico 8. Variação quantitativa do material lítico do sítio Antiqueira. 


\subsubsection{O Aproveitamento da Matéria-Prima Lítica}

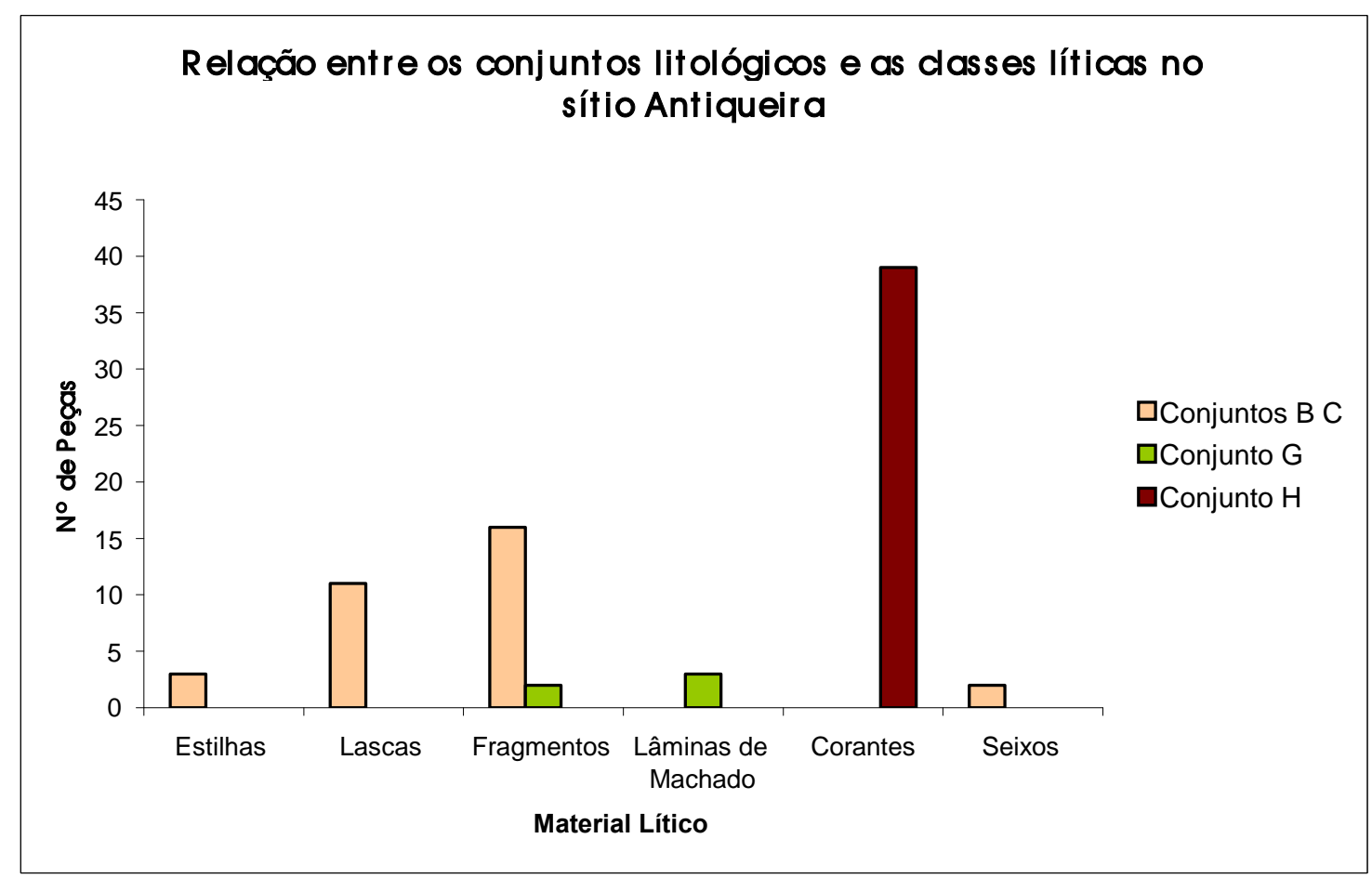

Gráfico 9. Histograma representando a relação entre os conjuntos litológicos e as classes líticas no sítio Antiqueira

No gráfico 9 pode ser observado a pouca variedade litológica do material lítico, as rochas metamórficas do conjunto $\mathrm{G}$ e G1, estão totalmente associadas a lâminas de machado lascados/polidos e a fragmentos. Os arenitos correspondem principalmente a fragmentos e lascas, principalmente em arenitos do conjunto $\mathrm{B}$, cujos afloramentos podem ser encontrados muito próximo aos do conjunto G.

\subsection{Sítio Arqueológico Caverna do Cipó}

Trata-se de uma caverna cuja entrada encontra-se a $8 \mathrm{~m}$ da superfície, tem cerca de $36 \mathrm{~m}$ de comprimento máximo (leste-oeste) e aproximadamente $14 \mathrm{~m}$ (norte-sul), a abertura da boca é de 29 m, e está voltada para a direção de onde se tem uma visão ampla e distante que abrange o rio Vermelho. 
Localizado em 1998, é o único sítio localizado na região da Cidade de Pedra que apresenta a ocorrência de remanescentes funerários. A área de preservação de restos esqueletais é restrita a pequena porção do sítio formada pelo acúmulo de sedimento represado por grandes blocos caídos que tornam a topografia do sítio extremamente heterogênea, seu sedimento é arenosos e seco.

De acordo com Wesolowski (2004), a associação entre fragmentos de cerâmica e de ossos humanos, a presença de dois sepultamentos em urna e a recorrência da forma dos vasilhames (todos do tipo urna) sugerem que todos os vasilhames descobertos no sítio fizeram parte de sepultamentos e provavelmente contiveram restos ósseos.

A autora comenta ainda que a dinâmica de formação do abrigo interferiu na disposição, preservação e distribuição do material arqueológico no sítio, ao mesmo tempo que alguns vestígios permaneceram no seu lugar de deposição original, uma grande quantidade de material arqueológico sofreu quebra, movimentação e redeposição relacionadas ou originadas por processos geológicos relativos a alterações mais recentes ocorridas no abrigo.

Segundo Wesolowski (2003), o padrão de sepultamento é aparentemente complexo, ocorrendo tanto sepultamentos feitos diretamente no solo (dois), quanto em urna (um, múltiplo de pelo menos três indivíduos). Espaços entre as rochas foram utilizados para depositar os sepultamentos, funcionando como uma espécie de nicho. $\mathrm{O}$ conjunto das evidências parece indicar o uso deste sítio como um espaço exclusiva ou pelo menos preferencialmente funerário para o período em torno de 1200 BP (datação obtida por termoluminescencia de um fragmento cerâmico.

A outra idade do sítio corresponde a uma datação de 7000 anos BP, obtida através de carvões associados a vestígios líticos encontradas na parte mais baixa e protegida do abrigo (Vilhena Vialou e Vialou 2000, 2003). 


\subsubsection{O Aproveitamento da Matéria-Prima Lítica}

\section{Material Lítico do Sítio Caverna do Cipó}

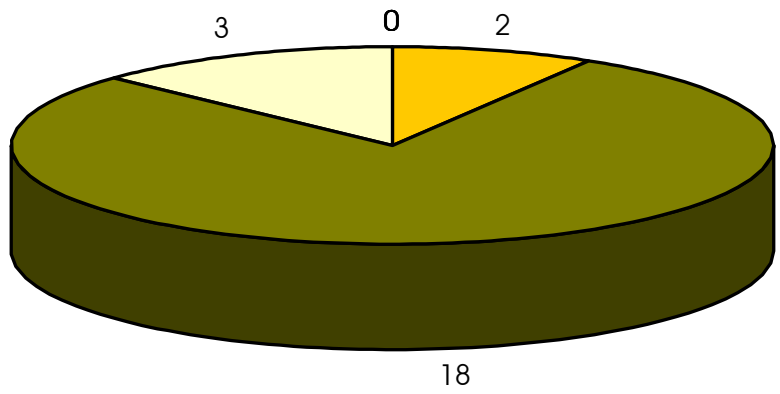

$\square$ Estilha

口Lasca

口Fragmento

口Núdeo

$\square$ Lômina de Machado

corante

Gráfico 10. Variação quantitativa do material lítico do sítio Antiqueira.

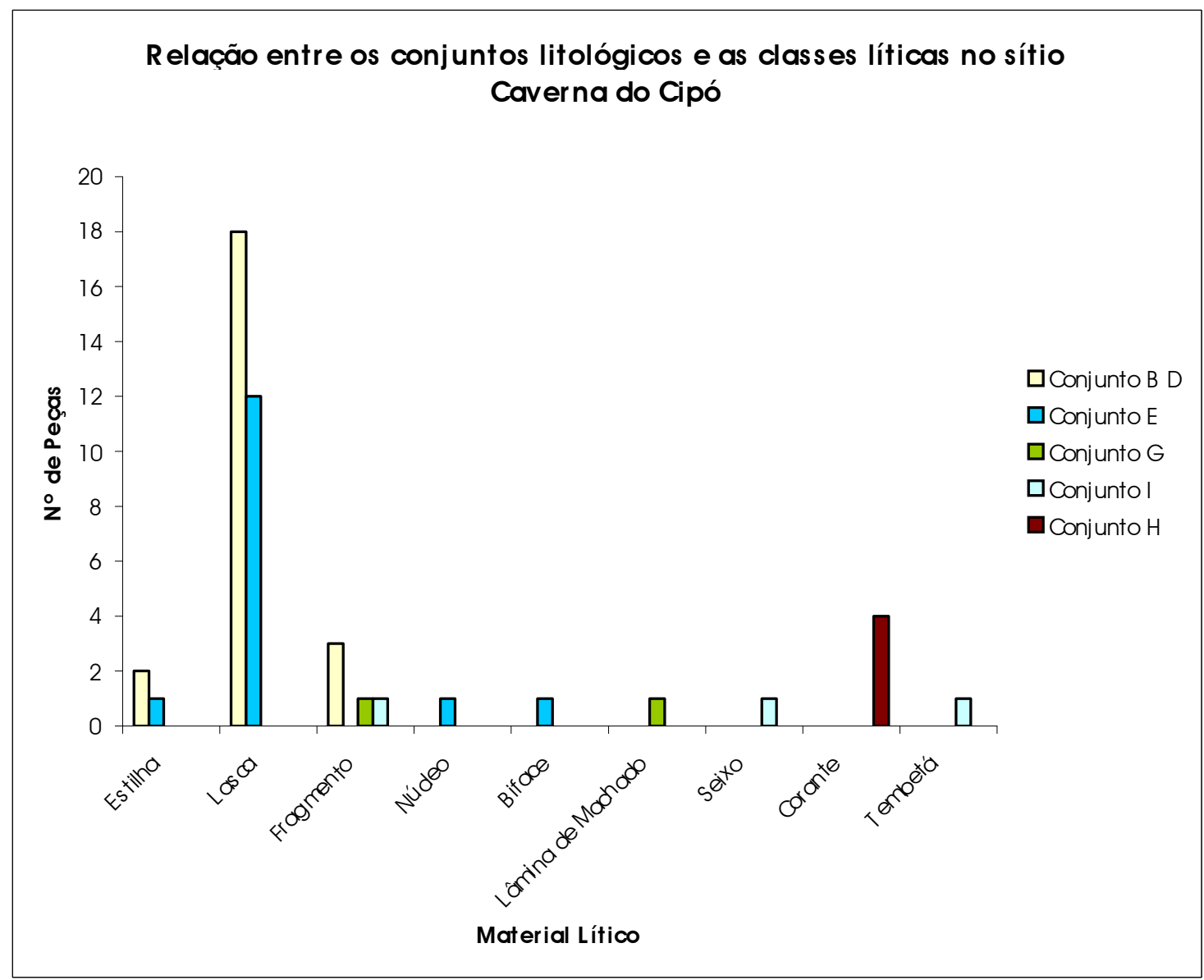

Gráfico 11. Histograma representando a relação entre os conjuntos litológicos e as classes líticas no sítio Caverna do Cipó 
O material lítico no sítio Cipó é escasso mas, bastante representativo, as rochas metamórficas do conjunto $\mathrm{G}$, ao contrário do que acontece nos outros sítios, quando está relacionada a toda uma fragmentação, nesse sítio está associada ao artefato, propriamente dito, no caso, uma lâmina de machado inteiramente polida, associada provavelmente aos sepultamentos.

O sílex, que de uma maneira geral, é uma matéria-prima rara na indústria lítica da Cidade de Pedra, no sítio Caverna do Cipó foi encontrada uma peça que apesar de não apresentar um trabalho humano nítido, é uma peça de proporções consideráveis (tamanho de um punho fechado), se comparada a forma de ocorrência nos demais sítios da área, onde o sílex está sempre relacionado a pequenas lascas e estilhas. Algumas outras lascas e fragmentos dos conjuntos B e D, além dos corantes relacionam-se a esses níveis mais recentes.

O adorno encontrado, diz respeito a um tembetá confeccionado em quartzo.

\subsection{Sítios Arqueológicos Fazendinha e Turbina}

São sítios a céu aberto cujos principais vestígios são cerâmicos, estão situados numa cronologia recente, não ultrapassando 2000 anos BP. Fazendinha, sítio que ocorre linearmente ao longo do rio Vermelho teve sua cerâmica datada de 600 e 800 anos BP. Esse sítio apresentam uma única camada imediatamente sob a camada superficial húmica. As diferenças constatadas na cerâmica parecem indicar vários períodos de ocupação em locais distintos associados possivelmente a diferentes culturas (Vilhena Vialou e Vialou, 2000 e 2003 e Figuti e Monteiro, 2003).

No sítio Fazendinha são encontrados poucos vestígios líticos, estes porém são muito mais volumosos, como grandes placas de rochas metamórficas, bem como lâminas de machado e fragmentos e lascas dos arenitos do conjunto D. As estilhas são menos freqüentes. Não há sinais de um primeiro trabalho sobre a matéria-prima, nessa área da margem do rio Vermelho.

O sítio Turbina localiza-se a cerca de $1 \mathrm{~km}$ do sítio Fazendinha, está implantado junto a escarpa arenítica, que delimita os lados leste e sul do sítio, sendo que a oeste está 
o córrego Sucuri, cuja microbacia é a rota natural de acesso à Cidade de Pedra (Monteiro, 2003).

Também no sítio Turbina os poucos vestígios líticos estão representados principalmente pelos conjuntos $\mathrm{D}$ e $\mathrm{G}$, sendo o conjunto $\mathrm{G}$ associado a polimento, que assim como nos demais sítios ocorrem de forma a aproveitar as superfícies dos planos de fratura.

Esses sítios estão localizados na planície do rio Vermelho, ao contrário do que acontece nos sítios em abrigo, essa é uma área bastante perturbada. A área onde se encontra o sítio Fazendinha é atualmente coberto por braquiária e já serviu para o plantio de alimentos como milho, feijão e arroz, enquanto que no sítio Turbina há atualmente um pomar, no entanto, neste sítio é possível encontrar material ainda estruturado (Monteiro, 2003). 


\section{Considerações Finais}

As escavações que vem sendo desenvolvidas na região demonstram através do material e das datações obtidas que a diferenciação mais notável é o aparecimento da cerâmica. Em Ferraz Egreja, Abrigos Vermelhos e Cipó, a cerâmica não existe antes de 1900 anos. As ocupações registradas anteriores a esse período estão presentes apenas às indústrias líticas lascadas, estas, de uma maneira geral ocorrem, sobretudo em arenito fortemente silicificado (conjunto D) e em silexitos, sem que tenham sido observadas mudanças na forma de lascar na transição do período sem cerâmica para o período com cerâmica (Vialou e Vilhena Vialou, 2003). No entanto, a introdução da cerâmica na região, de acordo com Vialou e Vilhena Vialou (2003), não implica aparentemente, em uma mudança de população, mas seria o resultado de uma nova aquisição técnica, que modificaria as condições econômicas do modo de vida sem com isso, incidir diretamente sobre o equipamento técnico em rocha.

Tal análise, contudo, não se aplica aos grupos instalados na planície aluvial, que compõem as paisagens abertas ao longo do eixo fluvial, nessas áreas, como ocorre em várias outras áreas do planalto central (Robrhan-González, 1996), a distribuição dos vestígios ocorre em amplitude e com volume de material cerâmico muito superior aos abrigos, enquanto que o material lítico é bastante reduzido (Vialou e Vilhena Vialou, 2003).

Contudo, apesar de todas as diferentes características referentes à inserção na paisagem, o período cerâmico é caracterizado pela existência de peças líticas polidas, tanto nos sítios a céu aberto, como nos sítios em abrigo. Essas peças estão associadas principalmente às rochas metamórficas (conjunto G1) que ocorrem em todos os sítios estudados (ver tabela 4).

Essa matéria-prima é a que se encontra mais distante dos sítios arqueológicos da Cidade de Pedra, seu afloramento, conforme já descrito, ocorre na borda do platô já em direção ao Pantanal, de forma que para sua aquisição é necessário ultrapassar o conjunto geográfico da Cidade de Pedra. Os vestígios arqueológicos confeccionados nessa matéria-prima, presentes nos sítios Ferraz Egreja e Vermelhos, estão relacionados a etapas de preparação de objetos polidos, no entanto, os artefatos inteiros são raros nesses sítios. Já nos demais sítios, Cipó, Antiqueira e Fazendinha as peças relacionadas a essas matérias-primas podem ser encontradas inteiras, sem que estejam associadas às 
etapas de fabricação. No caso do sítio Cipó, o único objeto inteiramente polido (forma de lâmina de machado) em contexto funerário, está associado a essa matéria-prima. Cabe ressaltar ainda que tanto em Cipó quanto em Arqueiros, a rocha é extremamente compacta (conjunto D), lembrando rochas ígneas, já nos demais sítios, ocorrem tanto rochas compactas do conjunto $\mathrm{G}$, como as rochas mais finas e foliadas (conjunto $\mathrm{G} 1$ ), considerando também as alterações que podem ocorrer nessas rochas quanto à cor e textura, quando em contato com o sedimento úmido, como no caso de Ferraz Egreja.

Para estipular a distância entre a área fonte destas rochas e os sítios em estudo, foi considerado o que Geneste $(1985,1988)$ chamou de trajeto mínimo de deslocamento das matérias-primas, através de medidas feitas em linha reta que permitem definir uma área mínima de circulação.

Tabela 4. Distâncias aproximadas entre os conjuntos litológicos G e G1 em relação aos sítios arqueológicos

\begin{tabular}{|l|c|c|c|c|c|c|c|}
\hline & $\begin{array}{c}\text { Ferraz } \\
\text { Egreja }\end{array}$ & $\begin{array}{c}\text { Vermelho } \\
\mathbf{s}\end{array}$ & Antiqueira & Cipó & Arqueiros & Turbina & Fazendinha \\
\hline Conjunto G & $19 \mathrm{~km}$ & $15 \mathrm{~km}$ & $17 \mathrm{~km}$ & $15 \mathrm{~km}$ & $10 \mathrm{~km}$ & $18 \mathrm{~km}$ & $19 \mathrm{~km}$ \\
\hline Conjunto G1 & $15 \mathrm{~km}$ & $11 \mathrm{~km}$ & $13 \mathrm{~km}$ & ---- & ---- & ---- & ---- \\
\hline
\end{tabular}

Tais medidas, no entanto, não podem ser consideradas para todos os sítios, pois a matéria-prima ao ser retirada da área fonte não foi deslocada diretamente para todos os sítios. Em Antiqueira e Cipó, por exemplo, ela é encontrada enquanto artefato, não há vestígios de processamento da matéria bruta nesses sítios. Já para Ferraz Egreja e Vermelhos, o deslocamento pode ter sido direto, tendo sido esses sítios os locais de preparo e distribuição dessa matéria-prima, isso sem excluir a possibilidade de que existam sitos mais próximos à área fonte.

Quanto a demais matérias-primas, nota-se que há algumas convergências entre os sítios arqueológicos da área, no que diz respeito à diversidade de matérias-primas e a presença de resíduos de lascamento.

Sendo Ferraz Egreja o sítio que apresenta toda a diversidade de matérias-primas identificadas. 
Tabela 5. Esquematização da relação entre os conjuntos de matéria-prima e os sítios arqueológicos.

\begin{tabular}{|l|c|c|c|c|c|c|c|c|c|c|c|}
\hline \multicolumn{1}{|c|}{$\begin{array}{c}\text { Sítios } \\
\text { Arqueológicos }\end{array}$} & \multicolumn{10}{|c|}{ Conjuntos Litológicos } \\
\cline { 2 - 12 } & A & B & C & C2 & D & E & F & G & G1 & H & I \\
\hline Ferraz Egreja & $\diamond$ & $\diamond$ & $\diamond$ & $\diamond$ & $\diamond$ & $\diamond$ & $\diamond$ & $\diamond$ & $\diamond$ & $\diamond$ & $\diamond$ \\
\hline Vermelhos & & $\diamond$ & $\diamond$ & $\diamond$ & $\diamond$ & $\diamond$ & $\diamond$ & $\diamond$ & $\diamond$ & $\diamond$ & $\diamond$ \\
\hline Antiqueira & & $\diamond$ & $\diamond$ & & & & & $\diamond$ & $\diamond$ & $\diamond$ & \\
\hline Cipó & & $\diamond$ & & $\diamond$ & & $\diamond$ & & $\diamond$ & & $\diamond$ & $\diamond$ \\
\hline Arqueiros & & & & & $\diamond$ & $\diamond$ & & $\diamond$ & & $\diamond$ & \\
\hline Fazendinha & & & & & $\diamond$ & $\diamond$ & & $\diamond$ & & & \\
\hline Turbina & & & & & $\diamond$ & $\diamond$ & & $\diamond$ & & & \\
\hline
\end{tabular}

Os arenitos (conjunto D) e os silexitos (conjunto E), por sua vez provêm do rio Vermelho que foi o agente transportador dessas matérias-primas advindas de outras formações geológicas a montante da Cidade de Pedra, já nas intermediações da área urbana de Rondonópolis. A problemática envolvendo esse tipo de fonte secundária foi apresentada no capítulo 4, o que se percebe nos sítios é que estas matérias-primas, especialmente os arenitos silicificados, foram amplamente utilizados, em Ferraz Egreja principalmente. No entanto, considerando que estas matérias-primas eram coletadas nas margens do rio Vermelho mais próximo a Cidade de Pedra não havia um controle muito grande sobre a coleta. Conforme atestado, o córtex liso e homogêneo omite o aspecto interno da rocha (se um arenito tem ou não uma boa silicificação), de forma que até que seja dado o primeiro golpe, não se sabe claramente o tipo exato de matéria-prima. Não há, dessa maneira, uma distinção prévia entre cores e texturas.

Esses recursos aluviais seriam então aparentemente mais fáceis de serem obtidos, com isso, mais eficientes, pois seriam recursos próximos e de qualidade.

As rochas obtidas nos afloramentos primários apresentam uma ampla variação nas cores e texturas, correspondentes aos aspectos geológicos das formações locais. Algumas dessas características, por serem homogêneas e recorrentes, foram agrupadas em conjuntos próprios, como é o caso do conjunto A, seus afloramentos, no entanto, são 
mais presentes nas áreas do platô. Os conjuntos $\mathrm{C}$ e $\mathrm{C} 2$, ocorrem pontualmente, em escala de afloramento, em quatro pontos identificados na Cidade de Pedra.

Por fim, pode-se dizer que não há uma associação nítida entre proximidade das fontes de captação e diversificação de matérias-primas, bem como, os dados quantitativos não estão relacionados a fatores tais como, a distância mínima de deslocamento, visto que a litologia do conjunto $\mathrm{G}$ é a matéria-prima mais distante e é quantitativamente expressiva nos sítios arqueológicos. Cabe ressaltar que devido aos contextos em que os artefatos feitos nessa rocha foram encontrados, pode ter sido um material "especial", o poderia justificar um maior empreendimento na sua coleta. Os dados obtidos demonstram que essa matéria-prima marca o período ceramista.

As demais matérias-primas foram exploradas localmente, e conforme já visto, não ocorrem diferenças expressivas entre as técnicas aplicadas ao lascamento dos diferentes tipos de arenitos e silexitos, tanto de origem primária como secundária. A utilização de uma matéria-prima de qualidade inferior, como é o caso, dos arenitos de fontes primárias, poderia estar relacionado à dificuldade em se coletar materiais mais aptos ao lascamento no rio Vermelho, visto que a disposição do material aluvionar é muito variável, tanto para os silexitos como para os arenitos, indo de acordo com a capacidade de transporte do rio, que pode alternar em épocas de secas e cheias. A partir dessas considerações, poder-se-ia supor que a coleta dessas rochas seria uma atividade sazonal, ou ainda esporádica, que estaria relacionada à dinâmica do rio. 


\section{Referências Bibliográficas}

AB'SABER, Naziz N. Os domínios de natureza no Brasil: potencialidades paisagísticas. São Paulo: Ateliê Editorial, 2003. 160 p.

AMBROSE, S.H. \& K. G. LORENZ. Social and ecological models for the Middle Stone Age in Southern Africa. The Emergence of Modern Humans. An archaeological perspective. Cornell University Press, New York, 1990.

ANDREFSKY, W. Jr. Raw-material availability and the organization of technology. American Antiquity, 59 (1), 1994. p. 21-34.

ARAUJO, A.G.M. As rochas silicosas como matéria-prima para o Homem PréHistórico: variedade, definições e conceitos. Revista do Museu de Arqueologia e Etnologia, São Paulo, 1991, 1:105-111.

ARAUJO, A.G.M. As Propriedades físicas dos arenitos silicificados e suas implicações na aptidão ao lascamento. Revista do Museu de Arqueologia e Etnologia, São Paulo, 1992, 2:63-74.

ARAUJO, A.G.M. As Geociências e suas implicações em teoria e métodos arqueológicos. Revista do Museu Arqueologia e Etnologia. 1999, Suplemento 3:3545.

ARAÚJO, J. F. V. et al. Manual técnico de geologia. Rio de Janeiro: IBGE, 1998, 306 p. (Manuais técnicos em geociências, $n^{\circ} 6$ ).

ASHMORE, W. and A.B. Knapp, (eds.) Archaeologies of Landscape. Blackwell publishers 1999.

AUBRY, T. L'exploitation des resources en matieres premieres lithiques dans les gisements Solutreens et Badegouliens du Bassin versant de la Creuse (France). Thèse pour obtenir le grade de Docteur. Paris, Université Bordeaux I, 1991.

BINFORD, L. R. Nunamiut Ethnoarchaeology. Academic Press, New York. 1978.

BINFORD, L R. Working at Archaeology. Academic Press, New York. 1983.

BINFORD, L. R. Em Busca Del Passado. S. L. Europa-America. 1991.

BLASIS, P.A.D.de. Abris Vermelhos, Mato Grosso. Premiers résultats. L'Anthropologie, t. 101, 3: 546-552, 1997.

BORGHI, L.,MOREIRA, M. I. C. Contribuição ao conhecimento do Paleozóico Inferior da Bacia do Paraná: Mapeamento geológico da região oriental de Chapada dos Guimarães, Estado de Mato Grosso. A Terra em Revista, 1998, 4:22-31. 
BRÉZILLON, M.N. L'outil préhistorique et te geste technique. L'Homme, hier et aujourd'hui - Récueil d'Études en Hommage a André Lroi-Gourhaan. Paris, Éditions Cujas, 1973.

BROWN, A.G. Alluvial Geoarchaeology. Floodplain archaeology and environmental change. Cambridge University Prese. 1997

BUTZER, K.W. Archaeology as Human Ecology. New York: Cambridge University Press, 1982.

CLARKE, D.L. Spatial information in archaeology. Spatial Archaeology. Academic Press, 1977, London: 1-32.

CUNHA, Sandra B. da. Geomorfologia Fluvial, In: Geomorfologia: uma atualização de bases e conceitos. $3^{\text {a }}$ Ed. Rio de Janeiro: Bertrand Brasil, 1998. p. 211-252.

DANA, J. D. Manual de mineralogia. Revisão de Cornelius S. Hurlbut Jr. Tradução de Rui Ribeiro Franco. Rio de Janeiro: Livros Técnicos e Científicos, 1974.

DAVIDSON, D.A.and ML. Shackley, (eds.) Geoarchaeology. Boulder, Colo: Westview Press, 1976.

DYSON-HUDSON, R., SMITH, E.A. Human territoriality: An ecological reassessment. American Anthropologist, 1978. 80:21-41.

FERNANDES, ACS, PEREIRA, E, BERGAMASCHI, S. A presença de Arthrophycus na Formação Vila Maria no município de Rondonópolis (MT). Anais da Academia Brasileira de Ciências, 1995, 67(3):383-384.

FUNDAÇÃO IBGE. Carta Brasil, esc. 1:100000, Folha Anhumas, MT. Rio de Janeiro, 1976.

FUNDAÇÃO IBGE Carta do Brasil, esc. 1:100000, Folha Rondonópolis, MT. Rio de Janeiro, 1976.

GALLAY, A. L'Archéologie demain. Paris: Belfond, 1986. 319 p.

GLADFELTER, B. G. Geoarchaeology: the Geomorphologist and archaeology. American Antiquity, 1977. 42: 519-538.

GLADFELTER, B.G. Developments and Directions in Geoarchaeology. In Advances in Archeological Method and Theory, ed. M. B. Schiffer, 1981. New York: Academic Press 4.343-64.

HARRIS, E. Principles of Archaeological Stratigraphy. Academic Press, 1989. 
HASSAN, F.A. Sediments in Archaeology: Methods and implications for paleoenvironmental and cultural analysis. Journal of Field Archaeology, 1978. 5:107-213.

HASSAN, F.A Geoarchaeology: the Geologist and Archaeology. American Antiquity 44: 267- 270. 1979

LAMING-EMPERAIRE. A. Guia para o estudo das Indústrias Líticas da América do Sul. Manuais da Arqueologia, nº 2, 174 p, 1967.

LANATA, J.L. Evolución, espacio y adaptación en grupos cazadores-recoletores. Revista do Museu de Arqueologia e Etnologia, São Paulo, 1993, 3: 3-15.

LEACH, E.K. On the definition of geoarchaeology. Geoarchaeology, 1992.7 (5): 405417.

LEROI-GOURHAN, A. Evolução e Técnicas: I- O Homem e a Matéria. Lisboa, Edições 70, 251 p., 1984.

LUEDTKE, B. E. The identification of sources of chert artifacts. American Antiquity. 1979. 44 (4): 744-756.

MORAIS, J.L. A propósito do estudo das indústrias líticas. Revista do Museu Paulista, 1987. São Paulo, 32:155-184.

MORAIS, J.L. Estudo do Sítio Camargo 2 -Piraju, SP: ensaio tecnotipológico de sua indústria lítica. Revista do Museu Paulista, 1988. São Paulo, 33: 41-128.

MORAIS, J.L. A Arqueologia e o fator geo. Revista do Museu de Arqueologia e Etnologia, 1999. São Paulo, 9:3-22.

MORAIS, J.L. A utilização dos afloramentos litológicos pelo homem pré-histórico brasileiro: análise do tratamento da matéria-prima. Coleção Museu Paulista, Arqueologia, São Paulo, volume 7, 1983.

MIGLIACIO, M. C.; CHIARI, S. I.; SILVA, V. C. F. e. Levantamento Arqueológico na Área de Influência das PCH's Embaúba e Cambará - Jaciara - MT, Relatório Final. 2004.

PAILlET, P. Art rupestre au Mato Grosso. Les abris Vermelhos. Archeologia, 1997. Dijon, 337: 50- 59.

PETTIJOHN, F. J. Sedimentary rocks. $2^{\text {nd }}$. New York: Harper \& Brothers, 1957. 718p.

PROUS, A. Arqueologia Brasileira. Brasília: Editora UNB, 1992. 
RAPP, Jr., G. \& Gifford, J. A. Archaeological Geology. Yale University Press. New Rave, Conn. 1985.

RAPP, Jr.,G. \& Hill, C.L. Geoachaeology. The Earth-Scince Approach to Archaeological lnterpretation. Yale University Press, 1998

RIBEIRO, Berta G. Os estudos de cultura material: propósitos e métodos. Revista do Museu Paulista. São Paulo, 1985. V.3, 13-41.

RENFREW, C. Archaeology and the Earth Scinces. In Geoarchaeology, ed. DA. Davidson and M. L. Shackley, 1-5. Boulder Colo: Westview Press, 1976.

RENFREW, C. \& BAHN, P. Arqueología: Teorías, Métodos y Práctica. Madrid: Ediciones Akal, Espanha, 1993.

RICKLIS, R. A.; COX, K. A. Examining lithic technological organization as a dynamic cultural subsystem: the advantages of an explicitly spatial approach. American Antiquity, 58 (3), 1993, p. 444-461.

ROBRHAN-GONZALEZ, E. M. Ocupação Ceramista do Brasil Central: Origens e Desenvolvimento. Tese de Doutorado, São Paulo, FFLCH-USP, 1996.

ROUBAULT, M. Détermination des mineraux des roches au microscope polarisant. Paris: Lamarre-Poinat, 350 p., 1963.

SANTOS, Jr. W. A. dos; RUIZ, A. S.;CASARIN, J. C.; CUTRIM, A. O.; \& SALOMÃO, F. X. de T. Caracterização geológica preliminar da área urbana de Rondonópolis (MT) e seu entorno. Anais do VI Simpósio de Geologia do Centro Oeste, Cuiabá, MT, 128-130, 1997.

SCHIFFER, M.B. Archaeological context and systemic context. American Antiquity, 1972. 37: 156-165.

SCHIFFER, M.B. Formation processes of the archaeological record. University of New Mexico Press, 1987.

SCHIFFER, M.B. The structure of archaeological theory. America Antiquity, 1988. 53: 461-485.

SCHMITZ, P. I. Caçadores e Coletores da Pré-História do Brasil. Instituto Anchietano de Pesquisas-UNISINOS, São Leopoldo, RS, 1984.

SCHMITZ, P. I. Caçadores-Coletores do Brasil Central, In: Pré-História da Terra Brasilis. Rio de Janeiro: Editora UFRJ, 2000. 380 p. 
SELLET, F. Chaine operatoire: the concept and its applications. Lithic Technology: 18 (1 e 2), 1993, p. 106-112.

SILVA, Fabiola Andréa. As tecnologias e seus significados. Um estudo da cerâmica Assurini do Xingu e da cestaria dos Kayapo-Xikrin sob uma perspectiva etnográfica. São Paulo, FFLCH, 2000.

STEIN, .J. K. Deposits for archaeologists. Advances archaeological method and theory, 11: 337-395. 1987

SUGUIO, K. Rochas sedimentares: propriedades, gênese, importância econômica. São Paulo: E. Blucher: Universidade de São Paulo, 1980, 500 p.

TIXIER, J., INIZAN, M-L \& ROCHE, H. Préhistoire de la pierre taillée. 1 terminologie et technologie. Antibes, CREP, 1980.

WESOLOWSKI, Verônica. Cidade de Pedra, MT: O espaço funerário da caverna do Cipó, In: Caderno de Resumos do XII Congresso da Sociedade de Arqueologia Brasileira, São Paulo, 2003.

VIALOU, D. Un nouveau site rupestre au Mato Grosso, l'abri Ferraz Egreja. Revista do Museu Paulista, nova série, São Paulo, 39: 39-53, 1983-1984.

VIALOU, D.;VILHENA-VIALOU, A. Préhistorie au coeur du Brésil. Archeologia, Dijon, 213: 36-48, 1985.

VIALOU, D; VILHENA VIALOU, A. Art rupestre, habitat et territoires au Brésil, In: R. de Balbin Bermann et P. Bueno Ramirez "El arte prehistorico desde los inícios del siglo XXI Primer Symposium Internacional de Arte Prehistorico de Ribadesella”. Asociación Cultural Amigos de Ribadesella, 2003, p. 481-512.

VILHENA DE MORAES, A. Estudo da indústria lítica proveniente da primeira campanha de escavações (1971) no sítio Almeida - Município de Tejupá, Estado de São Paulo. Coleção Museu Paulista, Série de Arqueologia 4, São Paulo, 1977.

VILHENA-VIALOU, A. Tecnotipologia das indústrias líticas do Sítio Almeida no seu quadro natural, arqueoetnológico e regional. Tese de Doutorado, São Paulo, FFLCH-Universidade de São Paulo, 1980.

VILHENA-VIALOU,A. Noções e revisões em terminologia e tecnotipologia lítica brasileira: problemas atuais. Sociedade ibero-americano, Reflexões e Pesquisas Recentes, Arno A. Kern (org.), Porto Alegre, EDUPUCRS, Coleção História 35. 345-362, 2000. 
VILHENA-VIALOU, A.; BLASIS, P. A. D. de; FIGUTI, L.; PAILLET, P. \& VIALOU, D. Art rupestre et habitats préhistoriques au Mato Grosso (Brésil). L'Amérique $d u$ sud: des chasseurs-cueilleurs à l'Empire Inca. BAR International series 746: 9-21. ARAPA, Genève, 1999.

VILHENA-VIALOU, A. Território, meio ambiente e culturas pré-históricas na Cidade de Pedra, Mato Grosso, In: Caderno de Resumos do XII Congresso da Sociedade de Arqueologia Brasileira, São Paulo, 2003.

VILHENA VIALOU, A. (org.). Pré-História do Mato-Grosso. Vol. 1: Santa Elina, São Paulo: Editora da USP, 2005. 256 p.

VILHENA VIALOU, A. (org.). Pré-História do Mato-Grosso. Vol. 2: Rondonópolis, São Paulo: Editora da USP, 2005 (no prelo)

VITA FINZI, C., HIGGS, E. Prehistoric economy in the Mount Carmel of Palestine: site catchment analysis. Proceedings of the Prehistoric Society. 36: 1-37, 1970.

WAGSTAFF, J.M., ed. Landscape and Culture: Geographical and Archaeological Perspectives. Oxford: Basil Blackwell, 1987

WATERS, M. R. Principles of Geoarchaeology: A North American Perspectives. Tucson: University of Arizona Press, 1992.

WATERS, M.R. \& Kuehn D. D. The geoarchaeology of place: the effect of geological processes on the preservation and interpretation of the archaeological record. American Antiquity, 1996. 61 (3): 499-519.

WILliAMS, H., TURNER, F. J., GILBERT, C. M. Petrografia: uma introdução ao estudo das rochas em seções delgadas. São Paulo: Polígono: Edusp, 424 p., 1970.

WINKLER, H. G. F. Petrogênese das rochas metamórficas. Tradução de Carlos Burguer Júnior. São Paulo: E. Blucher, Porto Alegre: Universidade do Rio Grande do Sul, 1977. 245 p.

WÜST, I. Contribuições arqueológicas, etnoarqueológicas e etno-históricas para o estudo dos grupos tribais do Brasil Central: o caso Bororo. Revista do Museu de Arqueologia, São Paulo, 2:13-26, 1992.

WÜST, I. Aspectos da ocupação pré-colonial em uma área do Mato Grosso de Goiás: tentativa de análise espacial. (2 V). Tese de Mestrado, São Paulo, FFLCHUniversidade de São Paulo, 1983.

WÜST, I. Continuidade e Mudança: para uma interpretação dos grupos ceramistas pré-coloniais da Bacia do rio Vermelho, Mato Grosso. Tese de Doutorado, São Paulo, FFLCH-Universidade de São Paulo, 1990. 
YARDLEY, B. W.D. An introduction to metamorphic petrology. New York: Lyiongman Scientific\& Techinical, 1989, 248 p.

\section{Relatórios}

BLASIS, P.A.D.de. Escavações no Abrigo Vermelho, In: L'Homme fossile et ses paléoenvironnements dans lê Bassin du Paraná-Brésil - Rapport de mission de recherche au Brésil, 1992-1993. Museu de Arqueologia e Etnologia da Universidade de São Paulo/ Muséum National d'Historie Naturelle; UA 184 du Centre National de la Recherche Scientifique; Ministère des Affaires Etrangères, Paris, 1993.

MARTINS, G.R. Pesquisas arqueológicas preliminares no Sítio caverna do Cipó, Rondonópolis, In: L'Homme fossile et ses paléoenvironnements dans lê Bassin $d u$ Paraná-Brésil - Rapport de mission de recherche au Brési,l 1999. Museu de Arqueologia e Etnologia da Universidade de São Paulo/ Muséum National d'Historie Naturelle; UA 184 du Centre National de la Recherche Scientifique; Ministère des Affaires Etrangères, Paris, 1999.

MINISTÉRIO DAS MINAS E ENERGIA - Secretaria Geral. Projeto RADAMBRASIL, Folha SD. 21 Cuiabá; geologia, geomorfologia, pedologia, vegetação e uso potencial da terra. Rio de Janeiro, volume 26, 1982, (il., 5 mapas).

MONTEIRO, L. C. Le site de Fazendinha, In: L'Homme fossile et ses paléoenvironnements dans lê Bassin du Paraná-Brésil - Rapport de mission de recherche au Brésil, 2003. Museu de Arqueologia e Etnologia da Universidade de São Paulo/ Muséum National d'Historie Naturelle; UA 184 du Centre National de la Recherche Scientifique; Ministère des Affaires Etrangères, Paris, 2003, p. 31-32.

MONTEIRO, L. C.; FIGUTI, L. Le site de la Turbina, In: L'Homme fossile et ses paléoenvironnements dans lê Bassin du Paraná-Brésil - Rapport de mission de recherche au Brésil, 2003. Museu de Arqueologia e Etnologia da Universidade de São Paulo/ Muséum National d'Historie Naturelle; UA 184 du Centre National de la Recherche Scientifique; Ministère des Affaires Etrangères, Paris, 2003, p. 32-34.

MONTEIRO, L. C.; FIGUTI, L. Sítios à céu aberto, In: L'Homme fossile et ses paléoenvironnements dans lê Bassin du Paraná-Brésil - Rapport de mission de recherche au Brésil 2004. Muséum National d'Historie Naturelle; UA 184 du Centre National de la Recherche Scientifique; Paris. Museu de Arqueologia e Etnologia da Universidade de São Paulo/ Muséum National d'Historie Naturelle; UA 184 du Centre National de la Recherche Scientifique; Ministère des Affaires Etrangères, Paris, 2004, p. 32-34. 
WESOLOWSKY, V. Escavações da Caverna do Cipó: Etapa de Pesquisa de Campo de 2004, In: L'Homme fossile et ses paléoenvironnements dans lê Bassin du ParanáBrésil - Rapport de mission de recherche au Brésil, 2004. Museu de Arqueologia e Etnologia da Universidade de São Paulo/ Muséum National d'Historie Naturelle; UA 184 du Centre National de la Recherche Scientifique; Ministère des Affaires Etrangères, Paris, 2004, p. 34-38.

VILHENA-VIALOU, A.; VIALOU, D.; FIGUTI, L.; BLASIS, P.A.D.de;(coords). L'Homme fossile et ses paléoenvironnements dans lê Bassin du Paraná-Brésil Rapport de mission de recherche au Brési, 1994. Museu de Arqueologia e Etnologia da Universidade de São Paulo/ Muséum National d'Historie Naturelle; UA 184 du Centre National de la Recherche Scientifique; Ministère des Affaires Etrangères, Paris, 1994.

VILHENA-VIALOU, A.; VIALOU, D.; FIGUTI, L.; BLASIS, P.A.D.de;(coords). L'Homme fossile et ses paléoenvironnements dans lê Bassin du Paraná-Brésil Rapport de mission de recherche au Brésil, 1997. Museu de Arqueologia e Etnologia da Universidade de São Paulo/ Muséum National d'Historie Naturelle; UA 184 du Centre National de la Recherche Scientifique; Ministère des Affaires Etrangères, Paris, 1997.

VILHENA-VIALOU, A.; VIALOU, D.; FIGUTI, L.; BLASIS, P.A.D.de;(coords). L'Homme fossile et ses paléoenvironnements dans lê Bassin du Paraná-Brésil Rapport de mission de recherche au Brésil, 1998. Museu de Arqueologia e Etnologia da Universidade de São Paulo/ Muséum National d'Historie Naturelle; UA 184 du Centre National de la Recherche Scientifique; Ministère des Affaires Etrangères, Paris, 1998.

VILHENA-VIALOU, A.; VIALOU, D.; FIGUTI, L.; (coords). L'Homme fossile et ses paléoenvironnements dans lê Bassin du Paraná-Brésil - Rapport de mission de recherche au Brésil, 2000. Museu de Arqueologia e Etnologia da Universidade de São Paulo/ Muséum National d'Historie Naturelle; UA 184 du Centre National de la Recherche Scientifique; Ministère des Affaires Etrangères, Paris, 2000.

VILHENA-VIALOU, A.; VIALOU, D.; FIGUTI, L.; (coords). L'Homme fossile et ses paléoenvironnements dans lê Bassin du Paraná-Brésil - Rapport de mission de recherche au Brésil, 2003. Museu de Arqueologia e Etnologia da Universidade de São Paulo/ Muséum National d'Historie Naturelle; UA 184 du Centre National de la Recherche Scientifique; Ministère des Affaires Etrangères, Paris, 2003. 
VILHENA-VIALOU, A.; VIALOU, D.; FIGUTI, L.; (coords). L'Homme fossile et ses paléoenvironnements dans lê Bassin du Paraná-Brésil - Rapport de mission de recherche au Brésil, 2004. Museu de Arqueologia e Etnologia da Universidade de São Paulo/ Muséum National d'Historie Naturelle; UA 184 du Centre National de la Recherche Scientifique; Ministère des Affaires Etrangères, Paris, 2004.

SCISLEWSKI, G. Recursos Minerais de Rondonópolis, MT. Projeto Primaz-MT, Companhia de Recursos Minerais, 1999. 